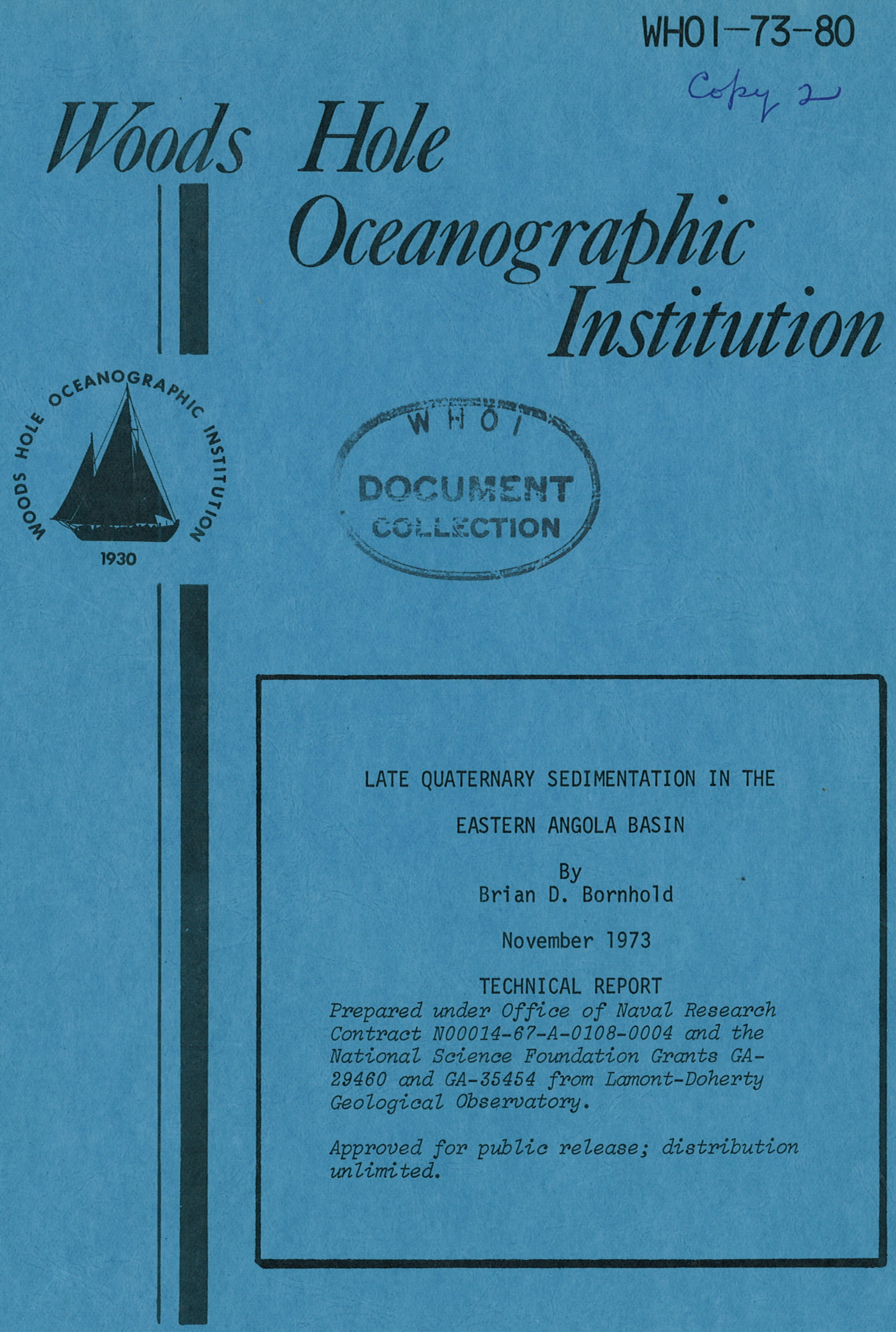

IVOODS HOLE, MASSACHUSETTS 02543 
WHOI $-73-80$

\title{
LATE QUATERNARY SEDIMENTATION IN THE EASTERN ANGOLA BASIN
}

\author{
By \\ Brian D. Bornhold \\ WOODS HOLE OCEANOGRAPHIC INSTITUTION \\ Woods Hole, Massachusetts 02543
}

November 1973

\begin{abstract}
TECHNICAL REPORT
Prepared under Office of Naval Research Contract N00014-67-A-0108-0004 and National Science Foundation Grants GA-29460 and GA35454 from the Lamont-Doherty Geological observatory.

Reproduction in whole or in part is permitted for any purpose of the United States Government. In citing this manuscript in a bibliography, the reference should be followed by the phrase: UNPUBLISHED MANUSCRIPT。

Approved for public release; distribution untimited.
\end{abstract}

Approved for Distribution

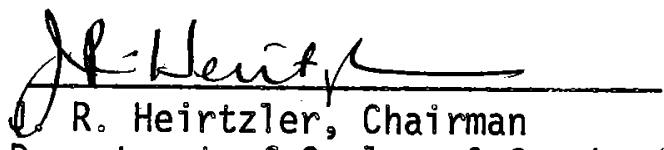

Department of Geology \& Geophysics 

LATE QUATERNARY SEDTMENTATION IN THE

EASTERN ANGOLA BASIN

by

BRIAN D. BORNHOLD

B.Sc. University of Waterloo

(1967)

A.M. Duke University

(1970)

SUBMITTED IN PARTIAL FULFILIMENT OF THE

REQUIREMENTS FOR THE DEGREE OF

DOCTOR OF PHILOSOPHY

at the

MASSACHUSETTS INSTITUTE OF TECHNOLOGY

and the

WOODS HOLE OCEANOGRAPHIC INSTITUTION

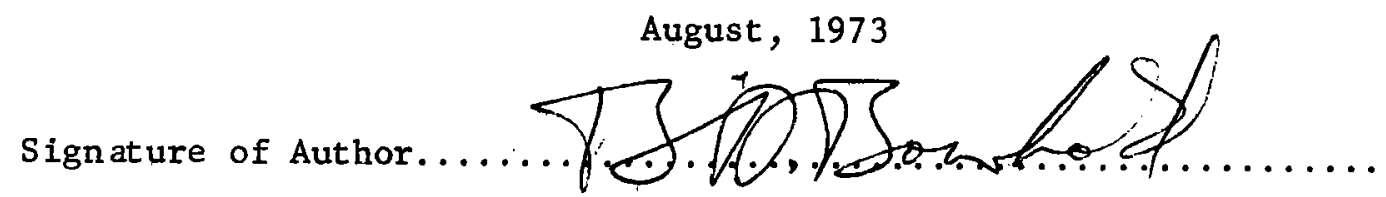

Joint Program in Oceanography, Massachusetts Institute of Technology - Woods Hole Oceanographic Institution, and Department of Earth and Planetary Sciences, and Department of Meteorology, Massachusetts Institute of Technoløgy, August, 1973

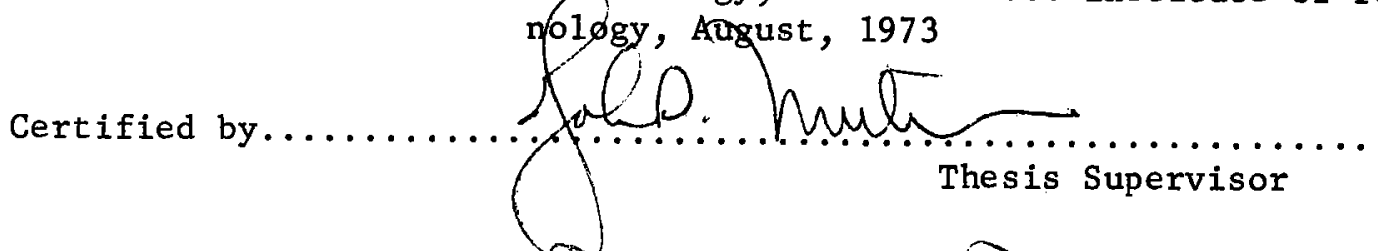

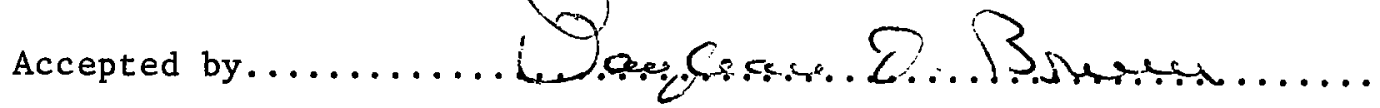

Chairman, Joint Oceanography Committee in the Earth Sciences, Massachusetts Institute of Technology - Woods Hole Oceanographic Institution 


$$
\text { • }
$$


LATE QUATERNARY SEDIMENTATION IN THE EASTERN ANGOLA BASIN

Brian D. Bornhold

Submitted to the Massachusetts Institute of Technology - Woods Hole Oceanographic Institution Joint Program in Oceanography on August 7, 1973 in partial fulfillment of the requirements for the degree of Doctor of Philosophy .

\section{ABSTRACT}

Recent sedimentation in the eastern Angola Basin includes calcareous oozes in the north and south (Guinea Rise and Walvis Ridge) and hemipelagic lutites and terrigenous turbidites on the Congo Cone and on the Angola rise and abyssal plain. Slumped and ponded sediments are dominant within the Angola diapir field. Illite and montmorillonite are abundant in the southern part of the basin, reflecting the source in soils of South West Africa and northward transport in the Benguela Current system. Kaolinite dominates the clay-mineral assemblage in the north-central part of the basin, reflecting a source in the tropical-humid Congo Basin and transport to the deep-sea through the Congo River and canyon systems.

Piston cores from the continental rise revealed major fluctuations in the surface oceanographic conditions, primary productivity, and near-bottom depositional environment during the late Quaternary. Sediments deposited during glacial intervals contain markedly lower carbonate, higher levels of organic carbon, and more abundant siliceous biogenic components, fecal pellets, and pyrite. Sedimentation rates during the past $200-300 \times 10^{3}$ years remained relatively constant on the rise, averaging $3-5 \mathrm{~cm} / 10^{3}$ years.

Oceanographic changes from interglacial to glacial periods, based on sediment composition and geochemistry, include:

(1) northward extension and intensification of the Benguela Current and associated high primary productivity off southern Angola;

(2) onset of upwelling and high surface productivity off northern Angola, Congo, and Gabon; and

(3) major influx of bottom water into the Angola and Guinea Basins.

These conditions resulted in higher benthic productivity, a shallower lysocline, and a more reducing near-bottom environment, as bottom water in the Angola Basin, produced during glacial maxima, became isolated. This "climax" bottom water was eventually mixed with the overlying water by gesthermal heating.

Thesis Supervisor: Dr. John D. Milliman

Title: Associate Scientist 


\section{ACKNOWLEDGEMENTS}

I wish to express my thanks to $\mathrm{Dr}$. John D. Milliman for his excellent guidance and encouragement throughout this research project. I should also like to thank Dr. K. O. Emery for enabling me to participate in the WALDA expedition of the N/O "Jean Charcot" in 1971 and in the Eastern Atlantic Contine ntal Margin study of R/V "Atlantis II" in 1972, and for permitting me to use samples and data collected from these cruises.

I also wish to thank Messrs. Guy Pautot, Danie1 Reyss, and Vincent Renard of the Centre Oceanologique de Bretagne for their excellent cooperation and assistance during the WALDA cruise and M. Léo Pastouret for his help in describing the piston cores in Brest, France.

I am very grateful, as we11, to the following individuals who supplied samples which were used in this study: Dr. George Keller (NOAA), Dr. Howard Sanders (WHOI), M. P. Giresse (Laboratoire de Géologie du Centre d'Enseignement Supérieur de Brazzaville), M. André Capart (Institut Royal des Sciences Naturelles de Belgique), and Mr. Roy Capo (Lamont-Doherty Geological Observatory). Cores were made available by the Lamont-Doherty Geological Observatory through NSF grants GA29460 and GA35454 and ONR grant N00014-67-A-0108-0004.

Mrs. Lois Toner provided invaluable advice and instruction in various laboratory methods and Mr. Jack Hathaway provided helpful advice on the X-ray diffraction methods.

The following people critically read the manuscripts and offered many helpful suggestions: Dr. K. O. Emery, Dr. Colin Summerhayes, Dr. John Southard, and Dr. John D. Milliman.

Fina11y, I should. like to thank my wife, Penelope, for her patience and 
encouragement throughout this study and for typing various parts of the manuscript. 
CONTENTS

Page

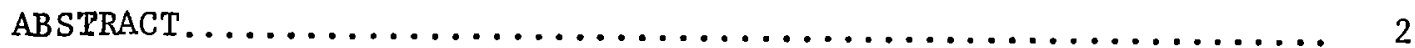

ACKNOWLEDGEMENTS............................ 3

LIST OF TABLES.............................. 7

LIST OF FIGURES $\ldots \ldots \ldots \ldots \ldots \ldots \ldots \ldots \ldots \ldots \ldots \ldots \ldots \ldots \ldots$

INTRODUCTION. ................................. 13

PHYSIOGRAPHIC SETTING....................... 17

Guinea Rise..................... 17

Congo Cone......................... 20

Angola Diapir Field................... 21

Angola Continental Rise................ 24

Walvis Ridge...................... 24

Angola Abyssal plain.................. 27

CLIMATE................................... 28

OCEANOGRAPHY $\ldots \ldots \ldots \ldots \ldots \ldots \ldots \ldots \ldots \ldots \ldots \ldots \ldots \ldots \ldots \ldots \ldots$

Surface Circulation................. 38

Bengue la Current................. 38

South Equatorial Countercurrent......... 41

Influx of Fresh Water.............. 42

Deep Circulation................... 42

Paleoclimatology and Oceanography.......... 52

DISTRIBUTION OF SUSPENDED MATTER.................. 59

Surface Suspended Matter............... 59

Suspended Matter Distribution.......... 59

Composition of Suspended Matter.......... 65 
Page

Suspended Matter in Deep Water............ 76

RECENT SEDIMENTS........................... 80

Calcium Carbonate.................. 80

Clay Minerals..................... 83

Methods....................... 83

Chlorite...................... 84

Montmorillonite................. 84

Kaolintte.................... 87

Illite...................... 87

Methods of Transport to the Deep Sea......... 87

LATE QUATERNARY SEDTMENTS..................... 93

Stratigraphy of Deep-Sea Cores............. 93

Abundance of the Globorotalia menardii 94 complex....................... 94

Paleoclimatic Curves and Stratigraphic Zonation................... 97

P1anktonic foraminifera/Radiolaria........ 100

Variations in Calcium Carbonate Abundance.... 100

Sedimentation Rates.................. 108

Sand and silt......................... 110

Turbidites..................... 118

Fecal Pellets and Authigenic Silicates...... 121

Vertical Changes in Clay-mineral Abundance...... 133

Organic Carbon......................... 133

DISCUSSTON.................................. 142

CONCLUSIONS.................................. 154

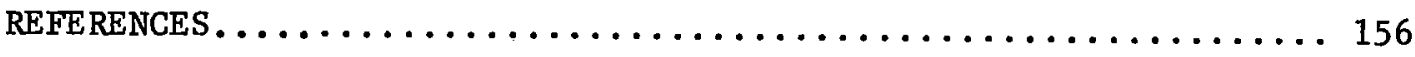

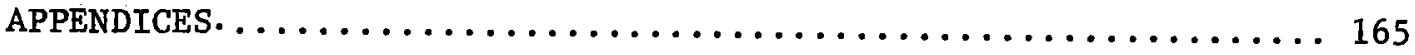




\section{LIST OF TABLES}

Table

Page

1. Sedimentation rates in the eastern Angola Basin..........109

2. Average organic carbon percent in glacial and interglacial sections of Angola Basin cores.........141 
LIST OF FIGURES

Figure

Page

1. Location of bott om samples in the Angola Basin............. 16

2. Bathymetry of Angola Basin showing major physiographic provinces.................................. 18

3. $3.5 \mathrm{kHz}$ echo-sounding record showing ponded sediments within the Angola diapir field................... 23

4. $3.5 \mathrm{kHz}$ echo-sounding record showing continental rise swells off southern Angola.................... 26

5. Climatic zonation of western Africa................ 30

6. Schematic interpretation of climatic features of an interglacial southern summer in western Africa.......... 32

7. Schematic interpretation of climatic features of an interglacial northern summer in western Africa.......... 34

8. Pattern of average annual rainfa11 in southwestern Africa...... 37

9. Pattern of surface circulation.................... 40

10. Surface salinity distribution.................... 44

11. (a) East-west profile of temperature across the South At lantic Ocean at Lat. $16^{\circ} \mathrm{s} \ldots \ldots \ldots \ldots \ldots \ldots \ldots \ldots \ldots \ldots \ldots$

(b) East-west profile temperature of salinity across the South Atlantic Ocean at Lat. $16^{\circ} \mathrm{S} \ldots \ldots \ldots \ldots \ldots \ldots \ldots . \ldots 49$

12. Distribution of potential temperatures of bottom water in the South Atlantic Ocean..................... 51

13. Schematic interpretation of climatic features of a glacial southern sumer.......................... 54

14. Schematic interpretation of climatic features of a glacial northern summer......................... 56

15. Distribution of total suspended matter concentration in surface waters........................... 61 
16. Relationship between salinity and total suspended matter concentration off the Congo River................6 63

17. Distribution of Fore1 color $(\%$ yellow) $\ldots \ldots \ldots \ldots \ldots \ldots \ldots \ldots$

18. Relationship between Forel color and total suspended matter concentration in the eastern Angola Basin............ 69

19. Distribution of Secchi disk transparency values........... 71

20. Photomicrograph of a fecal pellet in suspended matter

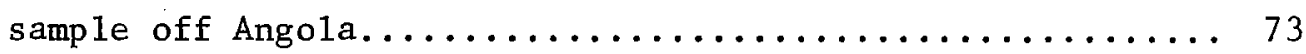

21. Photomicrograph of an organic aggregate in suspended matter

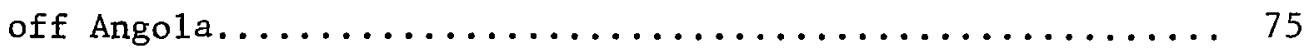

22. (a) Relationship between near-bottom suspended matter concentration and water depth in the eastern Angola Basin.... 78

(b) Relationship between light-scattering and water depth in the eastern Angola Basin................... 78

23. Distribution of percent calcium carbonate in surface sediments.. 82

24. Distribution of percent montmorillonite in the clay fraction of surface sediments................. 86

25. Distribution of percent kaolinite in the clay fraction of surface sediments....................... 89

26. Distribution of percent illite in the clay fraction of surface sediments........................ 91

27. Abundance of individua1s of the Globorotalia menardii complex in cores from the eastern Angola Basin.........96

28. Paleoclimatic curves and late Quaternary zonation based on the work of Emiliani (1971) and Huddlestun (1972)......99

29. Variations in the planktonic foraminifera/radiolaria ratios in cores from the eastern Angola Basin.......... 102

30. Variations in the calcium carbonate content of the silt and clay fraction in cores from the eastern 
Angola Basin..................................... 105

31. Relationship between percent sand, calcium carbonate content of the silt and clay fraction, and planktonic foraminiferal radiolaria ratios in core $v 19-281 \ldots \ldots \ldots \ldots \ldots \ldots \ldots \ldots \ldots \ldots$

32. Photomicrograph of smooth, spherical, non-magnetic particle

found in core $\mathrm{kW}-19 \ldots \ldots \ldots \ldots \ldots \ldots \ldots \ldots \ldots \ldots$

33. Photomicrograph of pyritized burrows from core v19-278....... 117

34. Average centimeters of silt and sand layers per meter of core... 120

35. Photomicrograph of chamosite pellets from the continental shelf off the Congo Republic.................... 123

36. Photomicrograph of grey pellets from core $\mathrm{kW}-15 \ldots \ldots \ldots \ldots \ldots \ldots$

37. Relationship between fecal pellet abundance, abundance of the

G. menardii complex, percent carbonate in the silt and clay fraction, percent sand, and the far aminifera/radiolaria

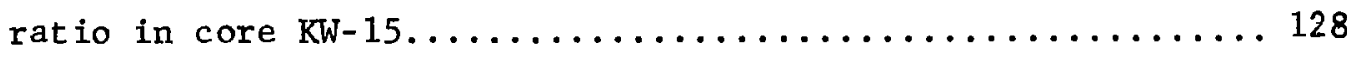

38. Photomicrograph of glauconite and chamosite pellets from the

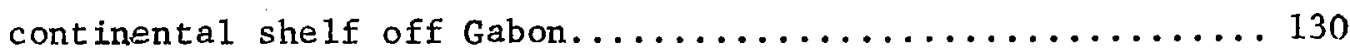

39. Photomicrograph of glauconite from core $\mathrm{KW}-18 \ldots \ldots \ldots \ldots \ldots \ldots \ldots$

40. Vertical changes in clay-mineral abundance in cores from the eastern Angola Basin......................... 135

41. Relationship between percent organic carbon, carbonate content of the silt and clay fraction, and abundance of the $\underline{G}$. menardii complex in cores V19-262, KW-19, and V19-281...... 137

42. Graphs of percent organic carbon versus carbonate content of the silt and clay fraction in cores V19-262 and v19-281....... 139

43. Schematic interpretation of bottom conditions in the Angola Basin during: (a) glacial maxima; (b) inter- 
Figure

Pape

mediate stages of warmer climate; and, (c) interglacial

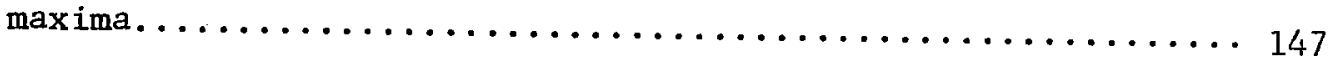

44. Depth of the lysocline in the equatorial south Atlantic....... 150 

LATE QUATERNARY SEDTMENTATION IN THE

EASTERN ANGOLA BASIN 

INTRODUCTION

The purpose of this investigation is to study the modern conditions of sedimentation in the Angola Basin and the changes brought about by variations in the climate of western Africa and in the oceanographic regime during the late Quaternary. Present sedimentation was studied by attempting to relate the composition and dispersal of suspended matter in the surface and deep water and the composition of surface sediments to the prevailing oceanographic and climatic conditions. Variations in sedimentary conditions and paleoenvironments during the late Quaternary were investigated by studying the composition of sediments in piston cores from the Angola Basin.

The interacting influences of climate and oceanographic conditions can have profound effects on sediment sources and volumes, on sedimentary processes, and on the environment of deposition. Until recently, studies of Quaternary marine sedimentation have been concerned primarily with establishing the details of paleoclimatology on the basis of planktonic assemblages, oxygen isotopic composition of foraminiferal tests, or calcium carbonate contents. On1y within the past few years has attention turned to the influence of changing surface and deep-sea circulation patterns on the nature of marine sedimentation (e.g., McIntyre and Ruddiman, 1972; Kennett and Brunner, 1973; Watkins and Kennett, 1972; Broecker, 1971).

The Angola Basin is well suited for a study of both paleoclimatological and paleooceanographic effects on sedimentation. The climate of tropical west Africa underwent major changes during the Quaternary, from tropical-humid during the interglacial periods to arid-semiarid during glacials. The circulation pattern of surface waters includes two contrasting current systems, 
the cold, productive, northward-flowing Benguela Current in the south and the warm, eastward-flowing South Equatorial Countercurrent farther north; models of Quaternary climatic variation based on studies of the adjacent areas of Africa, postulated important changes in this scheme. In addition, the nearly complete restriction of bottom waters of the basin at the present time offered the opportunity to study the effects of major changes in deep circulation on the nature of sedimentation during the late Quaternary. Sediment samples used in this study include both piston cores and bottom samples and were acquired from severa1 sources. Piston cores were obtained from the Lamont-Doherty Geologica1 Observatory, the Centre Oceanologique de Bretagne, and the Woods Hole Oceanographic Institution; grab samples were from the Centre Océanologique de Bretagne, Dr. Howard Sanders (WHOI), Woods Hole Oceanographic Institution, Bureau of Commercial Fisheries (courtesy of Dr. G. Keller), Institut Royal des Sciences Naturelles de Belgique, and M. P. Giresse (Congo Republic). The locations of these samples are included in Appendix $I$ and are shown in Figure 1. The suspended-matter samples were taken from the N/O "Jean Charcot" during the WALDA expedition of 1971 and from the $\mathrm{R} / \mathrm{V}$ "Atlantis II" during the Eastern Atlantic Continental Margin study of 1972. 
Figure 1. Location of bottom samples and core descriptions used in the investigation. 


\section{,}




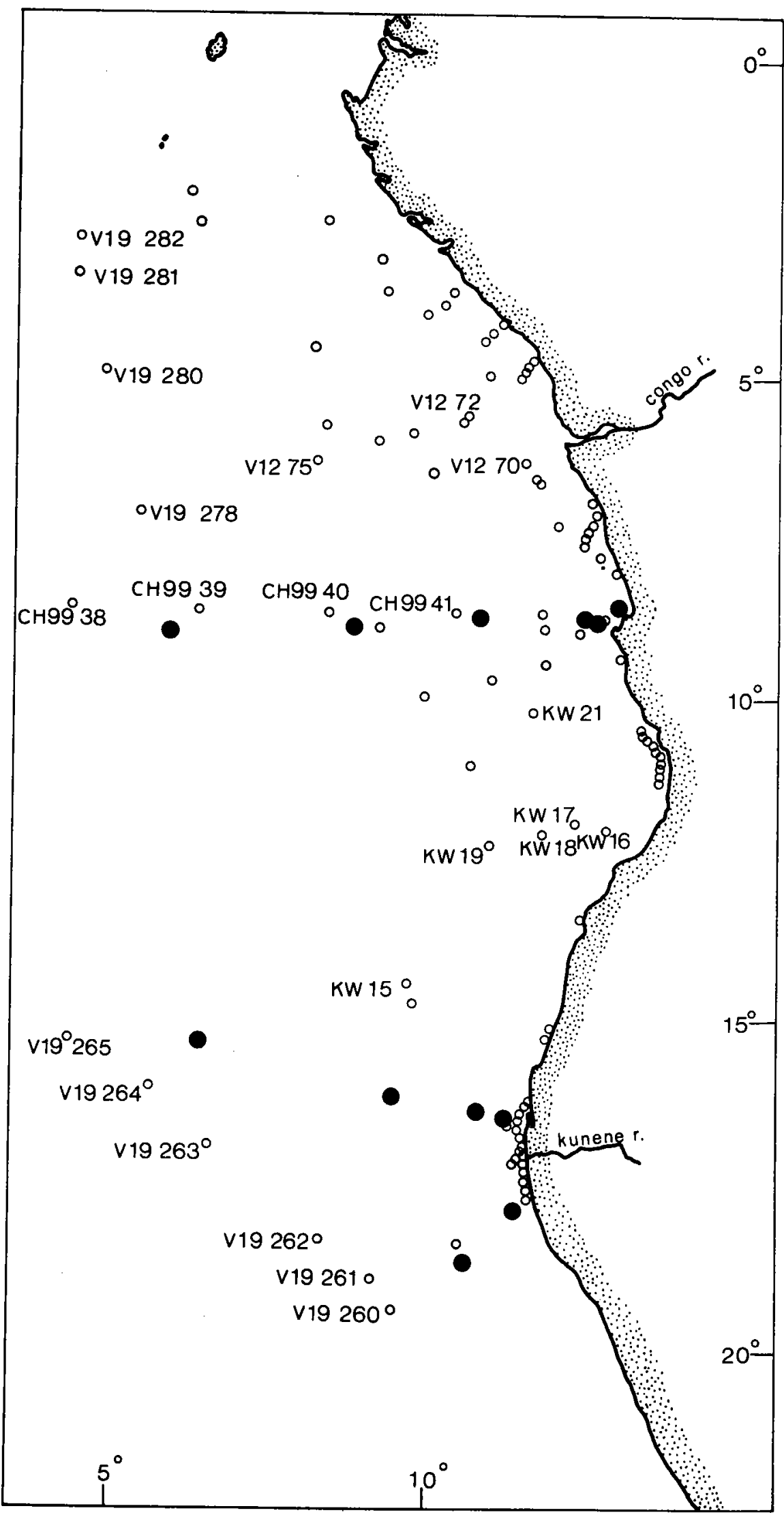

Figure 1 
, 
PHYS IOGRAPHIC SETTING

The coastal areas of Angola, Congo, and Gabon are characterized by a narrow zone of Cretaceous to late Cenozoic sedimentary rocks (10-100 km wide) to the east of which rises a long high plateau of Precambrian age. This plateau has its highest elevations in the south, averaging 1500 to $2000 \mathrm{~m}$, with the highest point $(2620 \mathrm{~m})$ being east of Lobito, Angola. The plateau descends towards the north, where it lies at 500 to $1000 \mathrm{~m}$ above sea leve1. The coasta1 plain is broadest in areas of major Tertiary embayments such as the Moçamedes, Cuanza, Cabinda, and Gabon Basins that have received considerable geological attention in view of their petroleum potentia1. The Congo River and its tributaries drain a large interior basin of Tertiary to Recent continental sediments.

The continental shelf in the study area is generally very narrow (Figure 2), particularly off southern Angola and immediately south of Luanda ( $<5 \mathrm{~km})$. It is wider off the Kunene River', South West Africa, and in the large reentrant of the coastline between Lat. $13^{\circ} \mathrm{S}$ and Luanda, Angola where it is 40 to $50 \mathrm{~km}$ wide. The shelf broadens steadily northward towards the mouth of the Congo River where it reaches a maximum width of about $80 \mathrm{~km}$. The shelf remains 40 to $60 \mathrm{~km}$ wide off Gabon and the Congo Republic.

The offshore area can be subdivided into six major physiographic regions; (1) the Guinea Rise; (2) the Congo Cone; (3) the Angola diapir field; (4) the Angola continental rise; (5) the northern Walvis Ridge; and, (6) the Angola abyssal plain.

\section{Guinea Rise}

The Guinea Rise is a broad swell separating the Angola Basin from the 

Figure 2. Bathymetry of the Angola Basin and adjacent continental margin. Depths are in corrected meters with a 400-meter contour interval (after Uchupi, 1972). 


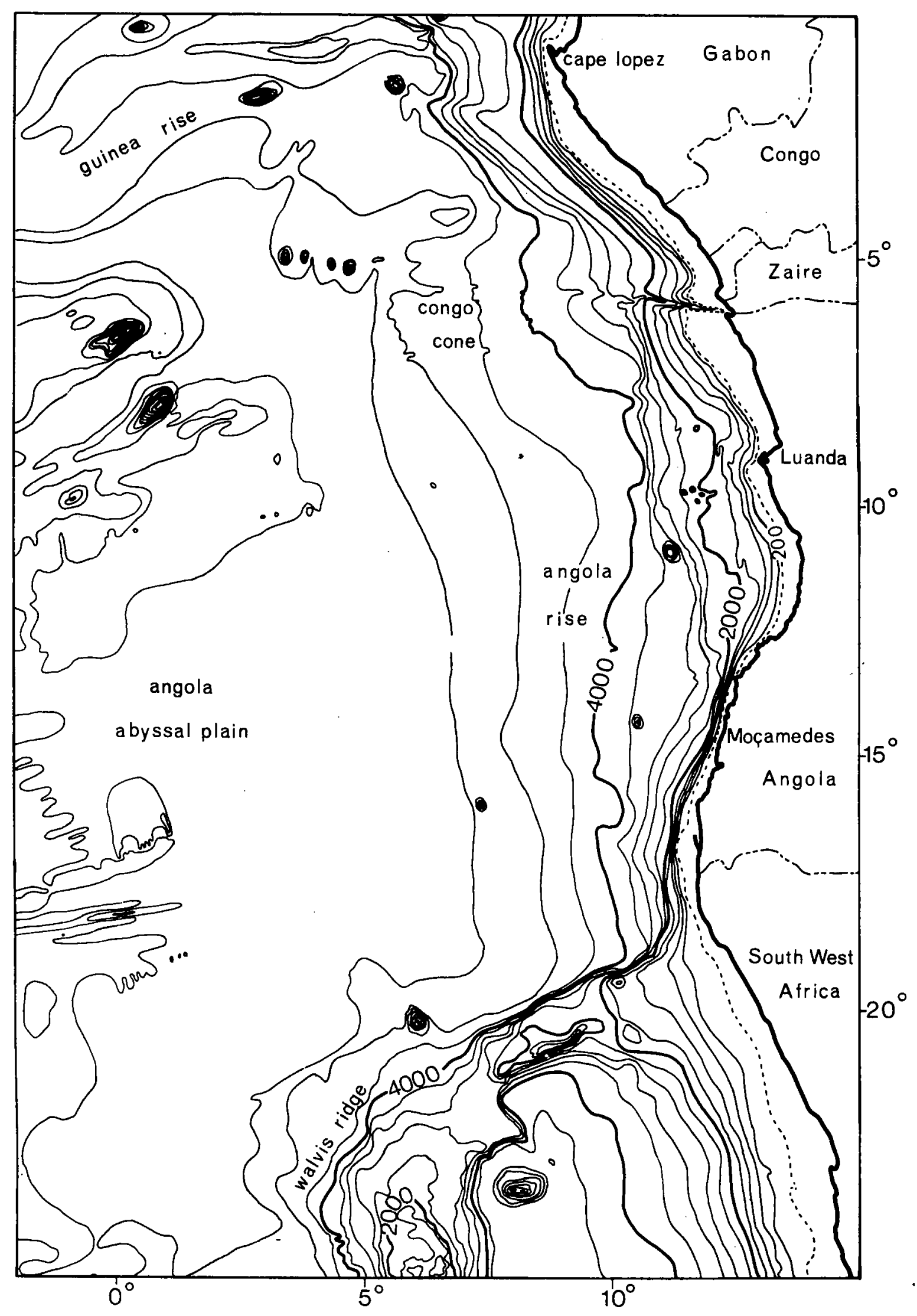

Figure 2 
Guinea Basin, thereby marking the northern boundary of the study area. It rises to approximately $4400 \mathrm{~m}$ depth from the Angola abyssal plain ( $>5200 \mathrm{~m}$ ) on the south and is characterized by numerous seamounts and volcanic islands of the Cameroon Line (Annabon, Principe, Sao Tome, and Fernando Poo). Continuous seismic profiling data show that the Guinea Rise has a highly irregular sub-bottom topography of very high relief, covered by a thick blanket of sediments (Heezen et al., 1964; Emery et a1., in prep). This topographic feature is believed to have been built primarily during the Cenozoic as a fracture zone-ridge system (LePtchon and Hayes, 1971).

\section{Congo Cone}

The Congo Cone occupies an area in excess of $250,000 \mathrm{~km}^{2}$ to the northeast of the Angola abyssal plain (Figure 2). The cone and in particular the associated canyon system have been the subject of a detailed investigation by Heezen et a1. (1964).

The cone is characterized by the undulating topography typical of an abyssal cone, being dissected by several canyon distributaries, especially west of $9^{\circ} \mathrm{E}$. The overall shape of the continental rise and slope is convex seaward in this region, in contrast to the slope and rise farther south which are concave seaward. A positive free-air gravity anomaly ( $>40$ mgal) is associated with the area west-southwest of the Congo River (Rabinowitz, 1972).

The following are the important aspects of the Congo canyon system and its deep-sea fan:

(1) the canyon extends $30 \mathrm{~km}$ into the mouth of the river and thus diverts virtually all of the river's bedload into the deep sea;

(2) the total length of the canyon system is $800 \mathrm{~km}$ and is made up in 
its lower parts of 8 to 10 branches (below $3500 \mathrm{~m}$ );

(3) the canyon is $V$-shaped to a depth of about $3500 \mathrm{~m}$, with the floor between 200 and $700 \mathrm{~m}$ below the level of the adjacent sea floor;

(4) below a depth of $3500 \mathrm{~m}$, the channel is defined primarily by natura1 levees.

\section{Angola Diapir Field}

The Angola diapir field has been the focus of several recent studies (Baumgartner and van Ande1, 1971; von Herzen et a1., 1972; Leyden et a1., 1972; Rabinowitz, 1972; Emery, 1973) in the light of the area's possible economic significance and of its position in the reconstruction of the South Atlantic. The evaporitic nature of these diapirs is supported by gravity, magnetics, heat flow, seismic refraction, and similarity to known salt diapirs.

The diapir field, which extends from about Lat. $13.5^{\circ} \mathrm{S}$ to at least as far north as Cape Lopez, lies at depths between approximately 1000 and $3500 \mathrm{~m}$ and is characterized by relief of up to several hundred meters. The field terminates abruptly on the seaward side as a steep scarp up to $1200 \mathrm{~m}$ in height. Articles by Leyden et al. (1972) and Mascle et al. (in press) suggest that this zone of diapirs may extend into the northern Gulf of Guinea, possibly as far as the Niger delta. This latter view is also supported by more recent geophysical data (Emery, personal communication).

On the basis of sediment ponding observed in seismic reflection profiling (Figure 3), detailed surveys of individual features, and gravity determinations, it has been concluded that many of these individual diapirs must form linear ridges up to $15 \mathrm{~km}$ long and roughly parallel to the bathymetric contours. 

Figure 3. $\quad 3.5 \mathrm{kHz}$ echo-sounding record showing ponded sediments within the Angola diapir field. 


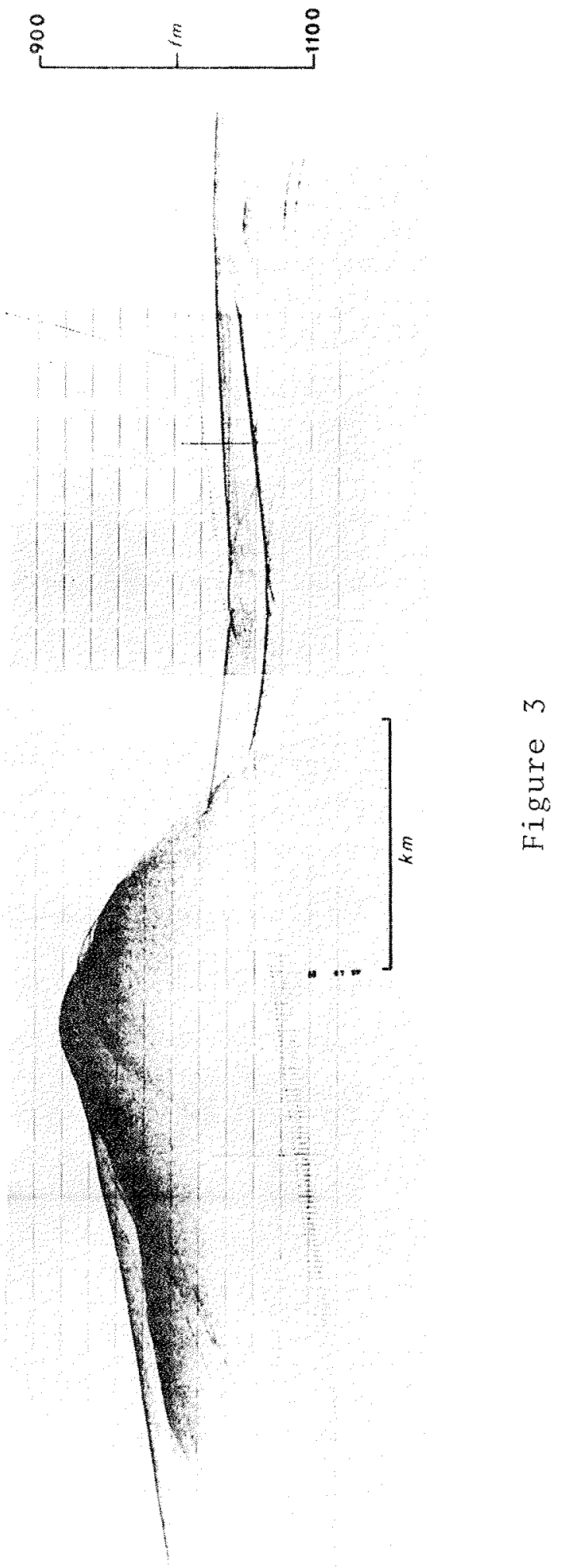
Angola Continenta1 Rise

The Angola continental rise includes the region bounded by the Congo cone to the north, the Angola diapir field to the east, the Walvis Ridge to the south, and the Angola abyssal plain to the west. It has smooth topography, broken only by occasional canyons, seamounts, and sma11, poorly developed continental rise hills (Figure 4). The last are most apparent at depths of about 4000 to $4500 \mathrm{~m}$ in the southeastern part of the area. The largest appear to be approximately $1500 \mathrm{~m}$ long and $30 \mathrm{~m} \mathrm{high}$ and are thought to be the products of deep currents. For reasons to be presented in a later section, these features are believed to be relict, dating from before the last major transgression.

\section{Walvis Ridge}

The Walvis Ridge, a major topographic and structural feature exhibiting rugged volcanic relief of several hundred meters, trends approximately NNESSW from the Mid-At lantic Ridge to the African continent, and separates the Cape Basin from the Angola Basin. Its northern sector is a more or less continuous unit with an average minimum depth of approximately $2500 \mathrm{~m}$. West of the study area (at about Long. $2^{\circ} \mathrm{E}$ ), the ridge is cut by a deep valley which reaches a depth of $4000 \mathrm{~m}$. The ridge is a less continuous feature west of this gap.

The steep north flank merges abruptly with the sea floor of the Angola Basin (Figure 2). Slump structures and the continental rise hills continue at least along the northeastern part of the Walvis Ridge. 
Figure 4. $\quad 3.5 \mathrm{kHz}$ echo-sounding record showing continental rise swells off southern Angola. 

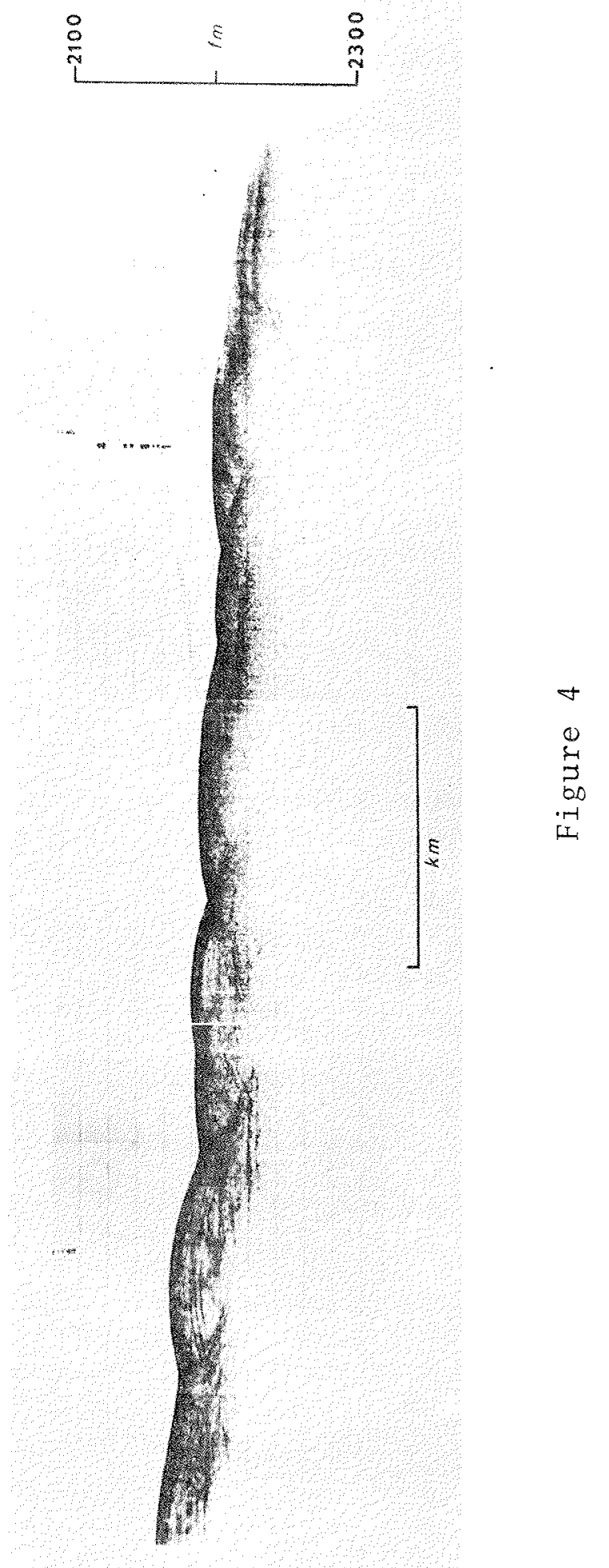
Angola Abyssal Plain

The abyssal plain occupies an area of approximately $15 \times 10^{5} \mathrm{sq} \mathrm{km}$ and lies at a depth of 5200-5600 m. It is essentially flat and featureless in its central portions. On the west it merges with the abyssal hill province of the Mid-Atlantic Ridge, on the north with the Congo cone, and elsewhere with the Angola continental rise or the similar topographic feature on the north flank of the Walvis Ridge. 
CLIMATE

The coastal region adjacent to the Angola Basin belongs primarily within the Class V or Tropical Climatic Zone of Landsberg et al. (1963) and embraces four of their five subdivisions within this zone, from "tropical humid-summer climate" to "tropical semi-desert and desert." These zones are arranged with the most humid in the north and the driest in the south (Figure 5); the southernmost sector of the area lies within Class IV or the Warm Temperate Subtropical Zone and in the "semi-desert and desert" subdivision of this zone.

Inland, the climatic zones penetrate far south of their coastal positions due to the presence of the nearby Precambrian plateau, located less than 100 kilometers inland (see pagel7). The major effect of this plateau is to increase rainfall in the interior; in southern Angola four major climatic zones occur within 400 kilometers of the coast. In the northern interior much of the Congo's drainage basin lies within a tropical-rainy climatic zone. This distribution of climatic zones has a profound influence upon the hydrologic regimes of the rivers in this area and $\mathrm{c}$ their contribution of sediment to the adjacent continental margin.

The climate and hydrographic conditions of this area are controlled principally by the presence of a major high-pressure area, the center of which is located at about Lat. $28^{\circ} \mathrm{S}$ and Long. $9^{\circ} \mathrm{W}$ in January and at about Lat. $24^{\circ} \mathrm{S}$ and Long. $13^{\circ} \mathrm{W}$ in July (Figures $6 \& 7$ ). In January, a major low-pressure area is centered over central equatorial Africa but moves far to the northeast by July.

Offshore, the anticyclonic circulation associated with this configuration gives rise to dominantly southeast trade winds in the entire area. These 
Figure 5. Climatic zonation of Africa (after Landsberg et al., 1963). Details for eastern Africa are not shown. 



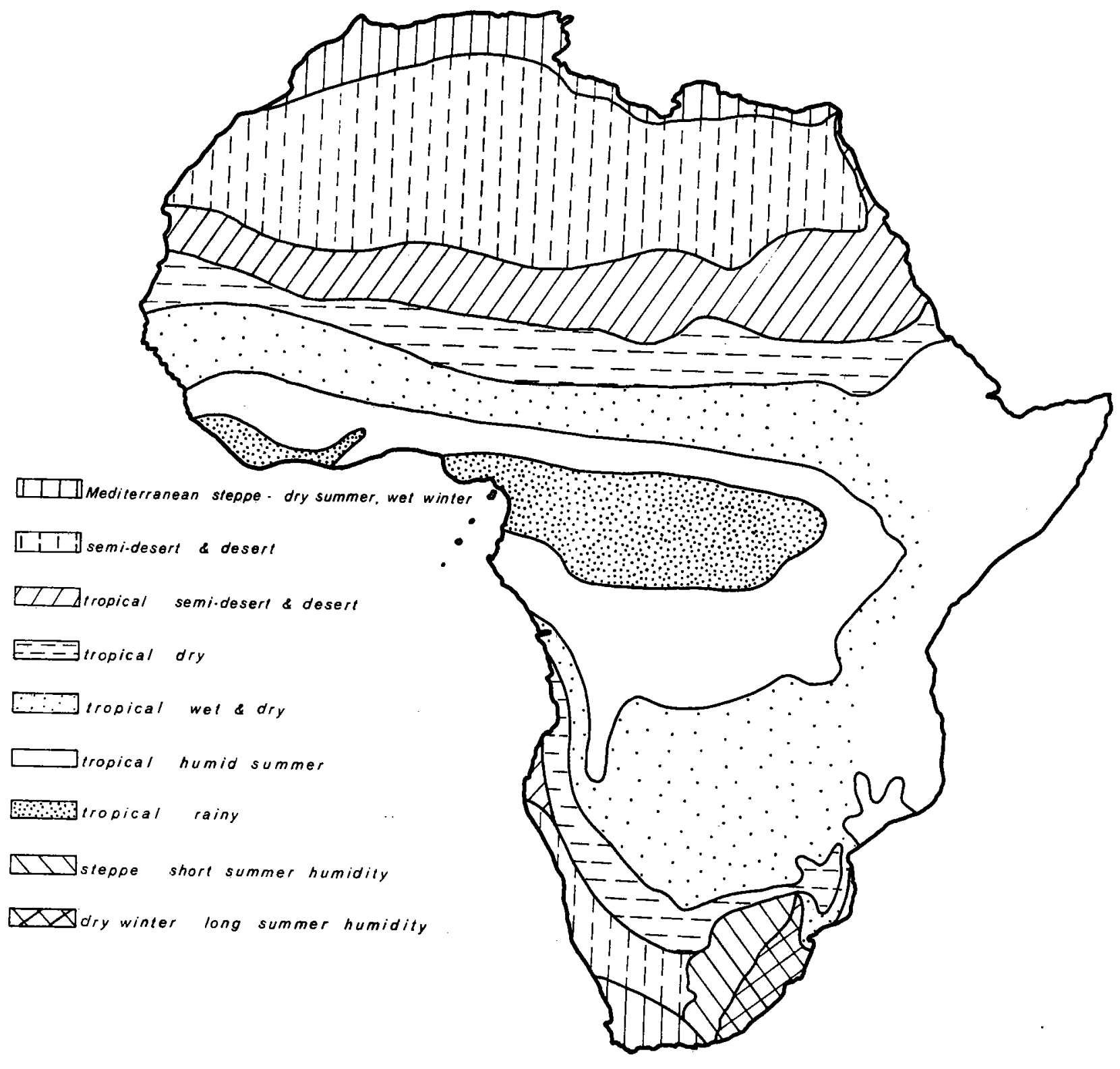

Figure 5 
Figure 6. Schematic interpretation of the important climatic

features during an interglacial southern summer in western Africa (after van Zinderen Bakker, 1967). Horizontal hatching indicates pluvial conditions; diagonal hatching indicates upwe11ing. 



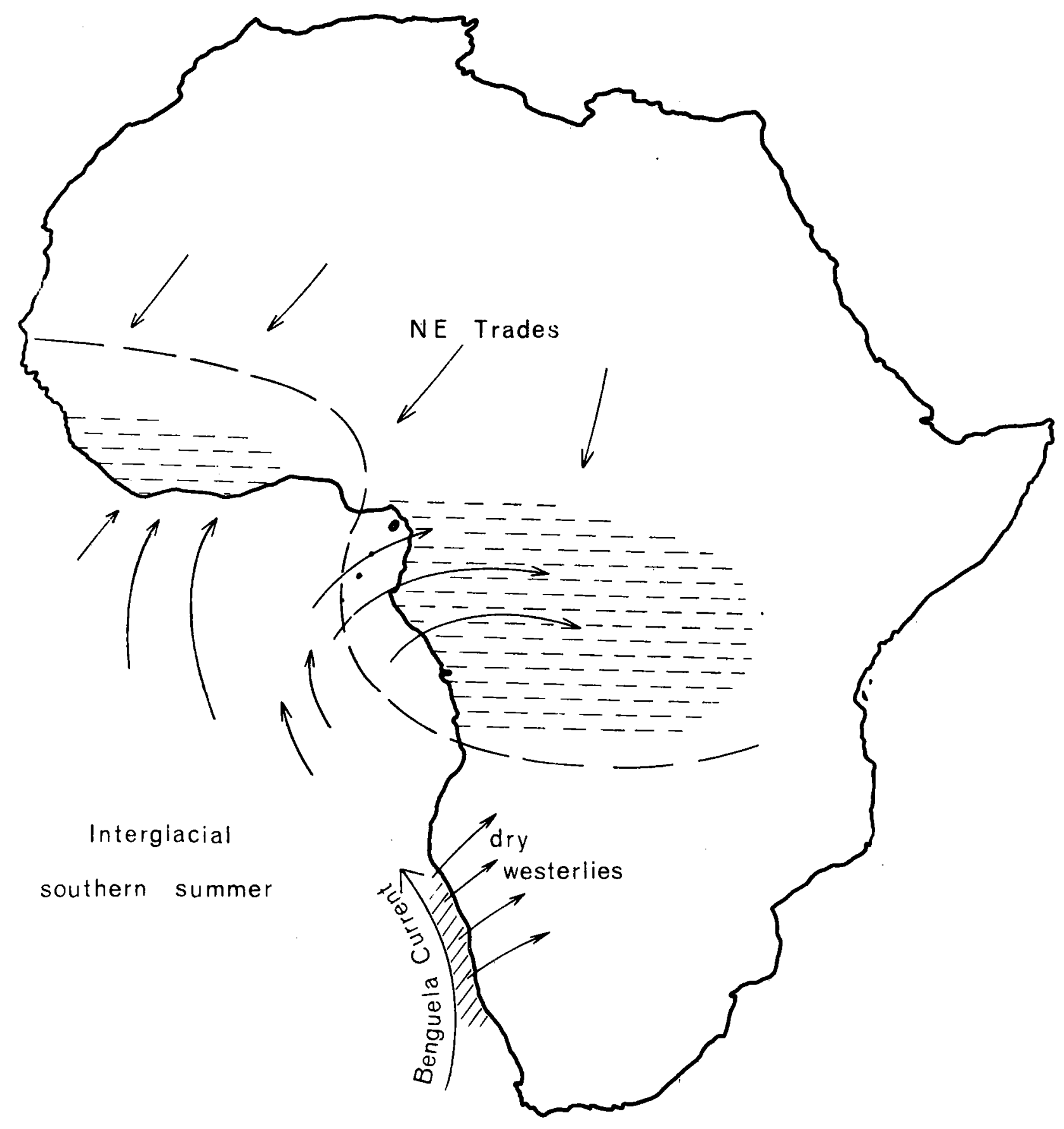

Figure 6 


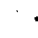


Figure 7. Schematic interpretation of the important climatic features during an interglacial northern summer in western Africa (after van Zinderen Bakker, 1967). 



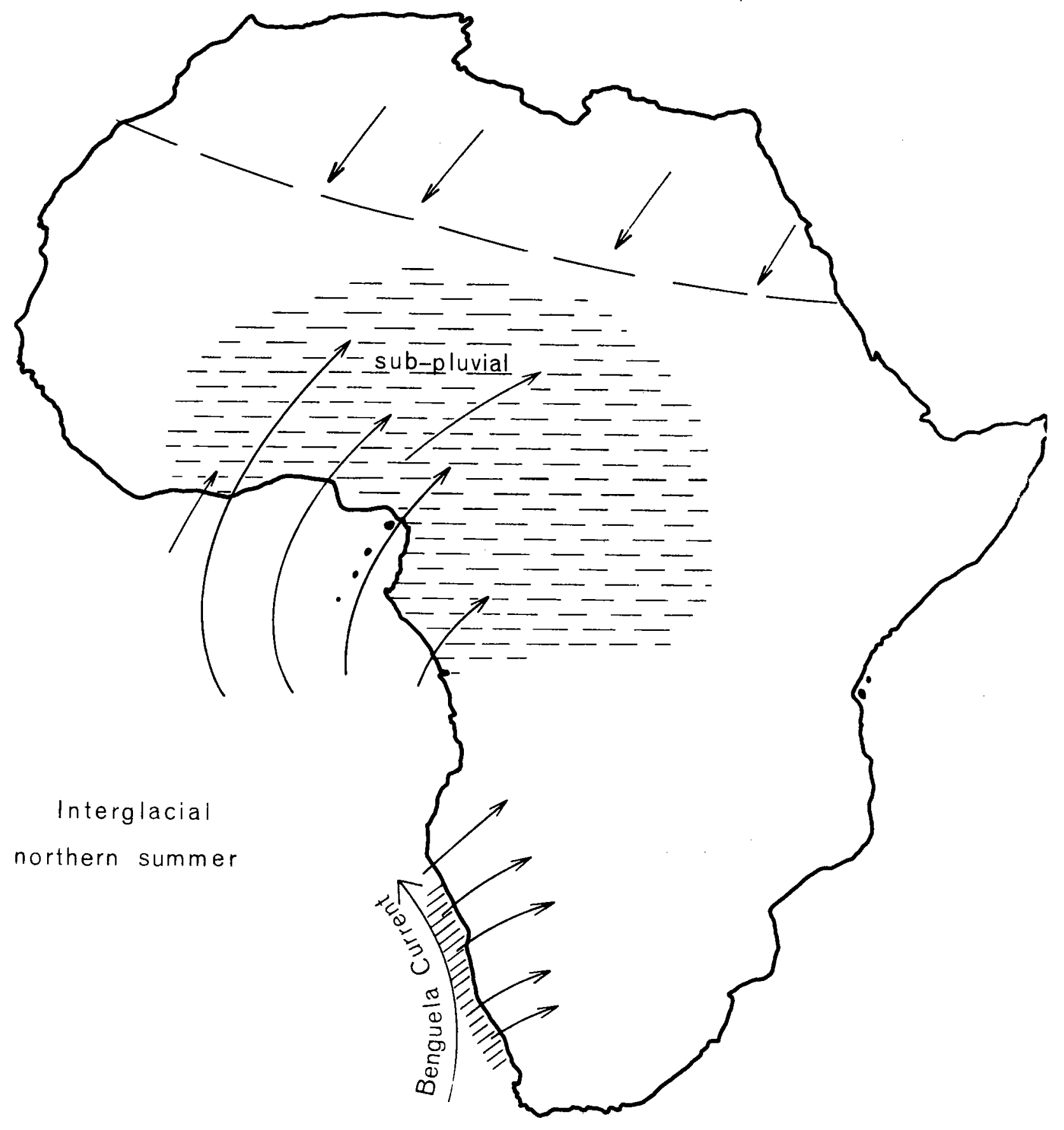

Figure 7 
southeast trade winds are particularly important in driving the Benguela Current (see below). As a result of the presence of a major cold water mass adjacent to shore, convectional winds very near the coast tend to be relatively dry.

The prevaling ocean winds are from the south or southeast. Winds average between Beaufort force 4 and 5 but are slightly stronger during the winter. North of $15^{\circ} \mathrm{S}$ the winds are more southerly and weaker.

In the interior of Angola and South West Africa easterly and southeasterly winds predominate with the strongest coming from a more southerly direction. Of particular interest with respect to potential offshore eolian transport of sediment off southern Angola and South West Africa are the Berg winds. These hot, dry, east winds blow from the plateau and generally are strong, gusty, and laden with dust and sand. These winds occur common $1 \mathrm{y}$ in winter, lasting from several hours to several days, and have velocities of over forty miles per hour $(20 \mathrm{~m} / \mathrm{sec})$.

Most of the coastal region receives very little rainfall diminishing from. north to south. Typical annual precipitation is shown in Figure 8 . Important rains in Angola come in summer (October-April) and are chiefly convectional. In the south, rain comes as occasional showers in late sumer. The isohyets in the study area closely parallel the coast (Figure 8) owing to the rapid rise in elevation. East of Mocamedes, Angola, on the plateau, the rainfall is more than $100 \mathrm{~cm} / \mathrm{yr}$ resulting in the almost annual flooding of the rivers of Angola, particularly the Cuanza, Cubal, Catumbela, Cuvo, Quicombo, and Corpolo. 
Figure 8. Pattern of average rainfall in Gabon, Congo Republic, Angola, and South West Africa (after Flint, 1959). 


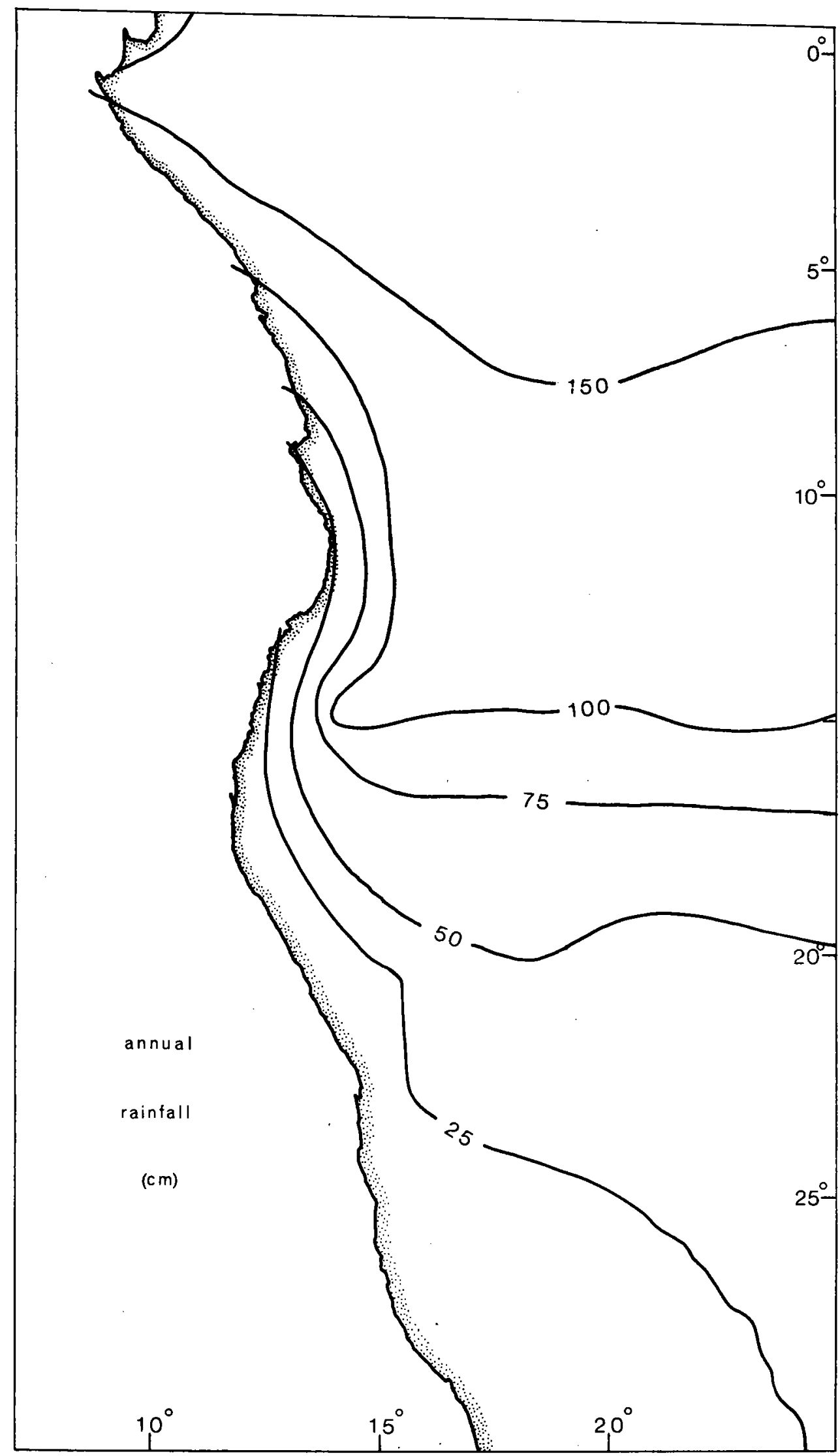

Figure 8 
OCEANOGRAPHY

\section{Surface Circulation}

The pattern of surface circulation is dominated in the south by the Benguela Current, in the north by the South Equatorial Countercurrent, and between Lat. $10^{\circ}$ and $20^{\circ} \mathrm{S}$, by their confluence in a complex of surface currents and gyres (Figure 9).

\section{Bengue la Current}

The Benguela Current, one of the world's major eastern boundary currents, owes its existence to wind stress on the sea surface by south and southeasterly winds and to the density gradients between cold upwelled water along the coast and warmer, lighter water farther west. The water upwelled along the South West African coast is South Atlantic central water, a mixture of sub-Antarctic and sub-tropical waters (Sche11, 1968). Drawn to the surface from depths of between 150 and $400 \mathrm{~m}$ (becoming shallower at lower latitudes), this deep water is characterized by its low temperature $\left(10^{\circ}-14^{\circ} \mathrm{C}\right)$, low salinity (34.6-35.0\%), high nutrient content, and low dissolved oxygen content.

The high nutrient content in surface waters causes high levels of biological productivity, up to $3.8 \mathrm{~g} \mathrm{C} / \mathrm{m}^{2} /$ day off South West Africa (Steeman Nielsen and Jensen, 1957). Eutrophication reduces the oxygen levels, resulting in the accumulation of organic, diatomaceous muds on the continental shelf off South West Africa.

Upwelling and the consequent high productivity within the Benguela Current decrease markedly north of about Lat. $23^{\circ} \mathrm{S}$ as the main branch of the current leaves the coast to flow northwestward and westward (Figure 9). A 
Figure 9. Pattern of surface currents over the eastern Angola Basin (after Moroshkin et a1., 1970). 


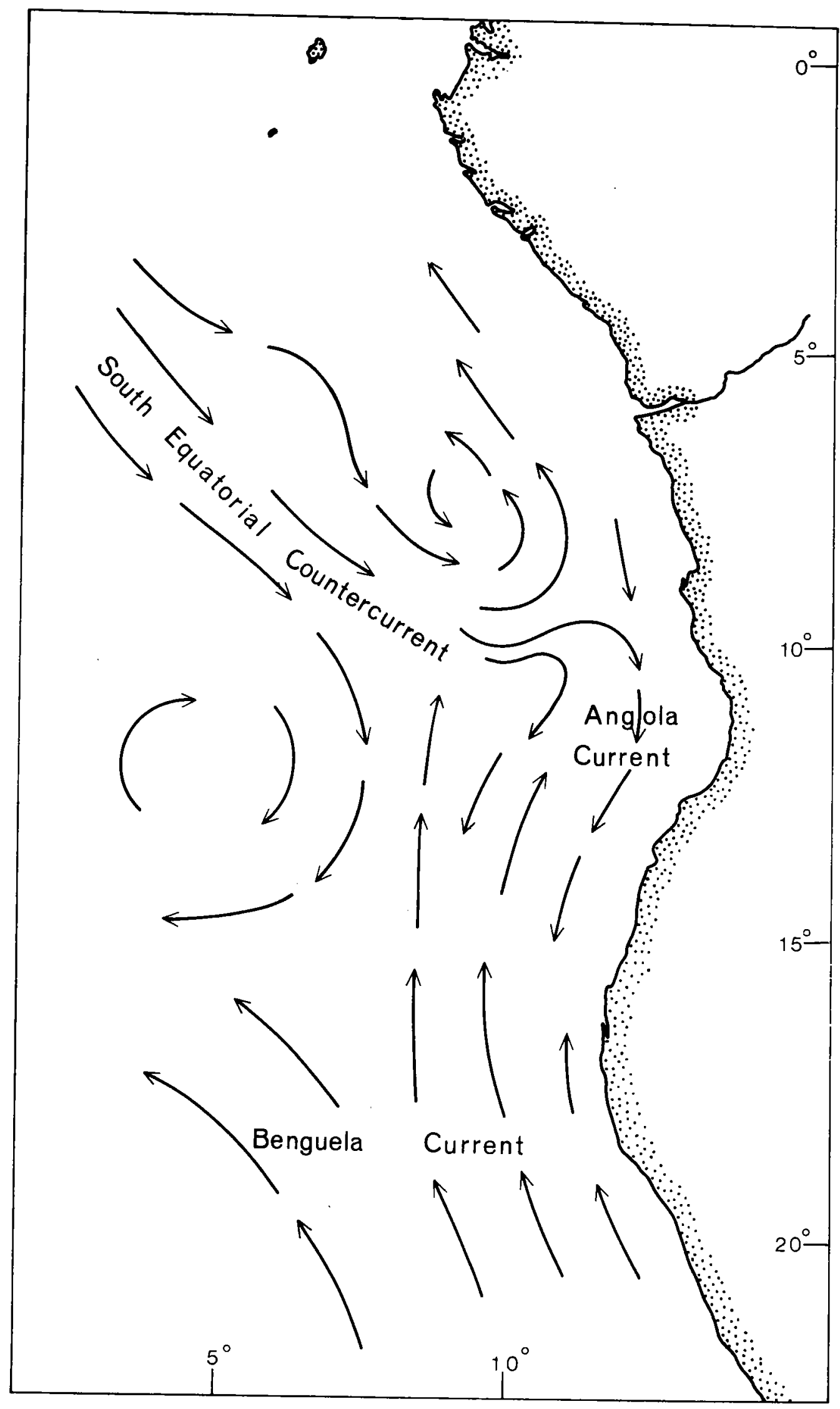

Figure 9 
smaller branch continues inshore off the coast of Angola. According to Moroshkin et al. (1970) this bifurcation of the Benguela Current between Lat. $20^{\circ}$ and $15^{\circ} \mathrm{S}$ gives rise to a smal1 zone of divergence over the north flank of the Walvis Ridge. Current velocities also diminish from south to north, being about $25-30 \mathrm{~cm} / \mathrm{sec}$ off South West Africa and $15-20 \mathrm{~cm} / \mathrm{sec}$ further north.

A southward-flowing countercurrent has been identified beneath the Benguela Current (Hart and Currie, 1960). The core of this oxygen-depleted current lies at approximate1y $300-400 \mathrm{~m}$ depth at $18^{\circ} \mathrm{S}$; the flow is several hundred meters thick and $400 \mathrm{~km}$ wide at this latitude. Its presence off South Africa a1so has been noted by DeDecker (1970). No estimates of current velocity have been made, though van Andel and Calvert (1971) suggest that such a current in the past may account for the erosion they infer to have taken place on the continental shelf between Lat. $20^{\circ}$ and $25^{\circ} \mathrm{S}$.

South Equatorial Countercurrent

This current flows generally eastward in a broad band between about Lat. $5^{\circ}$ and $9^{\circ} \mathrm{S}$ with velocities on the south of between 7 and $10 \mathrm{~cm} / \mathrm{sec}$, increasing to $30-50 \mathrm{~cm} / \mathrm{sec}$ on the northern edge of the flow. The width and velocity of the flow diminish markedly with depth; at $100 \mathrm{~m}$ depth the flow is about 150 $\mathrm{km}$ wide with velocities of about $3-5 \mathrm{~cm} / \mathrm{sec}$ on the south and $15-25 \mathrm{~cm} / \mathrm{sec}$ on the north.

Between Lat. $8^{\circ}$ and $9^{\circ} \mathrm{E}$, the current turns south, dividing into two branches. One forms an anticyclonic gyre centered at Lat. $7^{\circ} 30^{\prime} \mathrm{S}$ and Long. $9^{\circ} 30^{\prime} \mathrm{E}$; the other flows southward providing a source for the Angola Current. This latter name was proposed by Moroshkin et al. (1970) for the narrow, stable, fast ( $>50 \mathrm{~cm} / \mathrm{sec}$ ) southward flowing current along the Angolan coast. The orientation of shoreline features indicates that longshore drift, 
from South West Africa to Cape Lopez, is towards the north.

\section{Inf1ux of Fresh Water}

The Congo River represents the only major source of fresh water off west Africa between the Niger and Orange Rivers. In terms of discharge it ranks as the second largest river in the world $\left(1,400 \times 10^{9} \mathrm{~m}^{3}\right.$ annual discharge), its rate of discharge varying between $26,000 \mathrm{~m}^{3} / \mathrm{sec}$ in August to nearly $60,000 \mathrm{~m}^{3} / \mathrm{sec}$ in December (Donguy et a1., 1965).

Congo River water moves to the northwest as it enters the Atlantic Ocean (Figure 10). At about Long. $11^{\circ} \mathrm{E}$, the tongue broadens and moves to the south-southwest as far as about Long. $9^{\circ} \mathrm{E}$ where salinities of $35 \%$ are attained. A broad region of slightly lowered salinity can be traced as far south as Lat. $9^{\circ} \mathrm{S}$. In reality, however, this view of the Congo discharge is too simplistic: detailed continuous salinity measurements made during the WALDA expedition showed that the Congo River water is distributed in many narrow "streams" of low-salinity water separated by regions of nearly norma1 salinity.

\section{Deep Circulation}

The contrasting bottom water characteristics of the Angola Basin $\left(2.4^{\circ} \mathrm{C}\right.$, $34.89 \%)$ and the Cape Basin and western basins of the South Atlantic $\left(1.5^{\circ} \mathrm{C}\right.$, 34.77\%) led WUst (1933) to conclude that Antarctic Bottom Water was prevented from spreading into the eastern basins (Angola and Guinea) by the Walvis Ridge to the south and the Mid-Atlantic Ridge on the west. The differences in salinity and temperature between the Brazil Basin and the Angola Bas in are shown in the east-west profile at Lat. $16^{\circ} \mathrm{S}$ taken from Fuglister (1961) (Fig- 
Figure 10. Salinity distribution in surface waters overlying the Angola Basin based on data collected from the N/O "Jean Charcot" during the WALDA expedition of 1971 and from the R/V "Atlantis II" during the Eastern Atlantic Continental Margin Study of 1972 . 



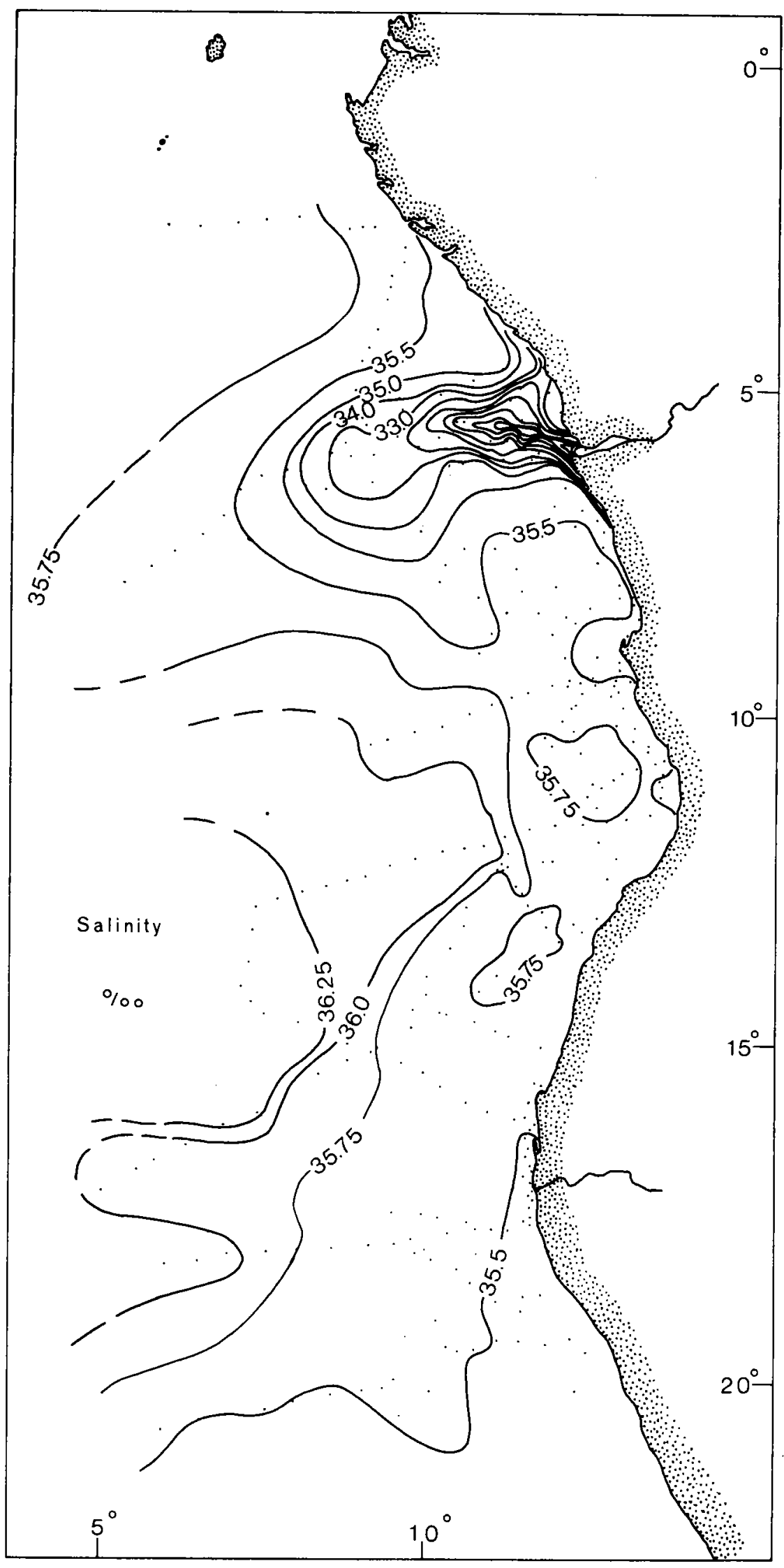

Figure 10 
ure 11).

On the basis of data presented in Fuglister (1961), Shannon and von Rijswijck (1969) believed that a sma11 amount of water enters the Angola Basin through a narrow gap in the Walvis Ridge at about Lat. $31^{\circ} \mathrm{S}$. Based on nephelometer studies, Connary and Ewing (1972) reached the same conclusion.

A sma11 amount of bottom water enters the Guinea and Angola Basins through equatorial fracture zones, in particular the Romanche Fracture Zone (Figure 12). Metcalf et al. (1964) determined that the sill depth in these fracture zones was at approximately 3750 meters. In turn, the Guinea and Angola Basins are separated by a si11 at approximately 4100 meters depth (Connary and Ewing, 1972).

WUst (1957) calculated geostrophic currents for the deep waters of the Angola Basin and concluded that the circulation was very sluggish (everywhere less than $5 \mathrm{~cm} / \mathrm{sec}$ ). Temperature and salinity data suggest that essentially homogeneous water exists below 4500 meters. Connary and Ewing (1972) found that the main nepheloid layer occupies the same homogeneous water mass, where settling velocities of particles are balanced by turbulence. They also found that light scattering within the Angola Basin was six times less intense than in the western North Atlantic and four times less than in the western South Atlantic and Cape Basin, further attesting to the sluggish circulation in this basin.

Photographic evidence also suggests slow bottom circulation. Heezen et a1. (1964) state: "The photographs indicate a generally muddy bottom with fairly abundant tracks and trails, and indicate a tranquil bottom unaffected by ocean currents." (p. 1140).

In 1 ight of the proposed slow circulation, the presence of well defined abyssal swells along the continental rise off southern Angola and along the 
Figure 11. (a) East-west profile of temperatures across the South Atlantic Ocean at Lat. $16^{\circ} \mathrm{S}$ (after Fuglister, 1961). 


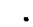

6 


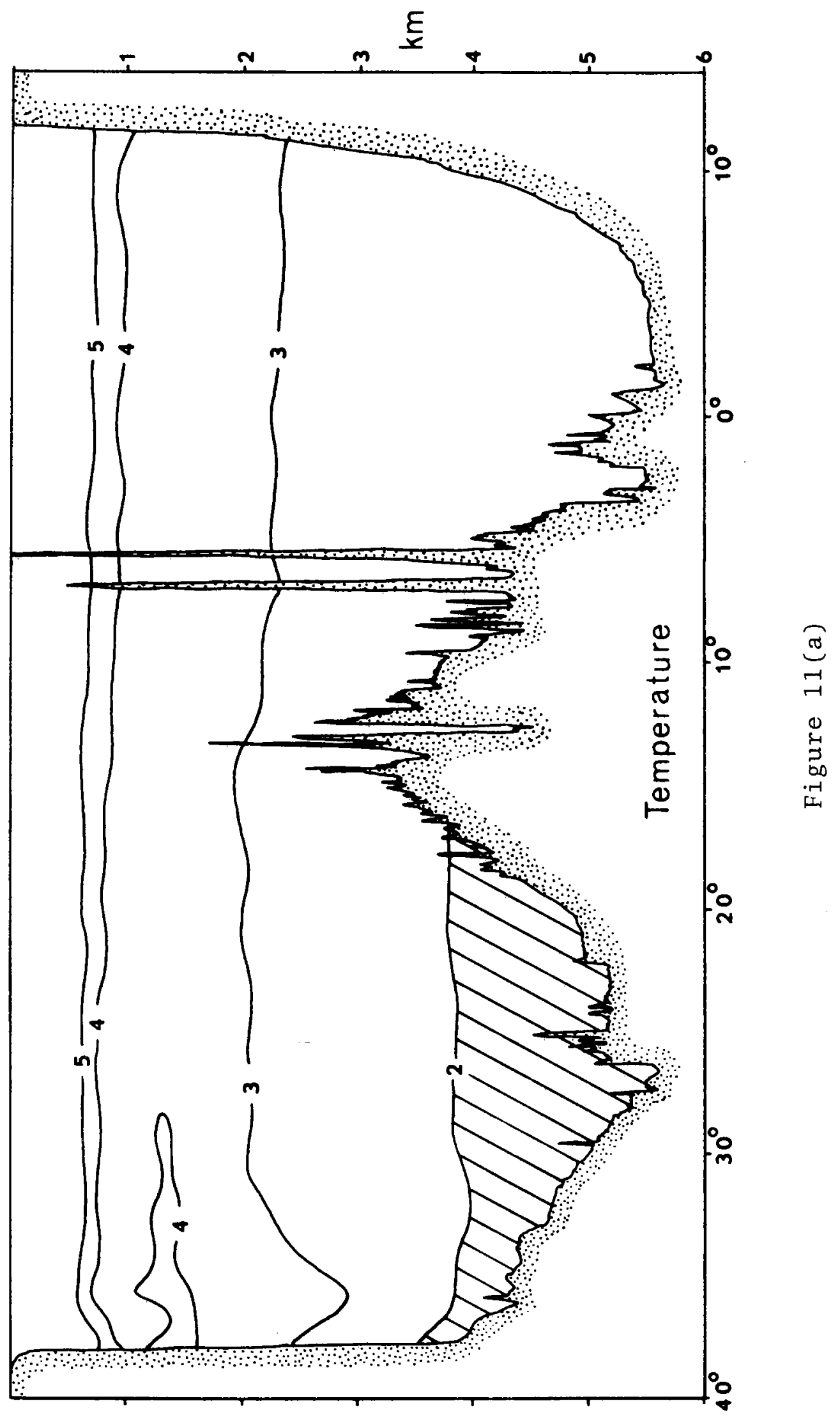



Figure 11. (b) East-west profile of salinity across the South At lantic Ocean at Lat. $16^{\circ} \mathrm{S}$ (after Fuglister, 1961). 


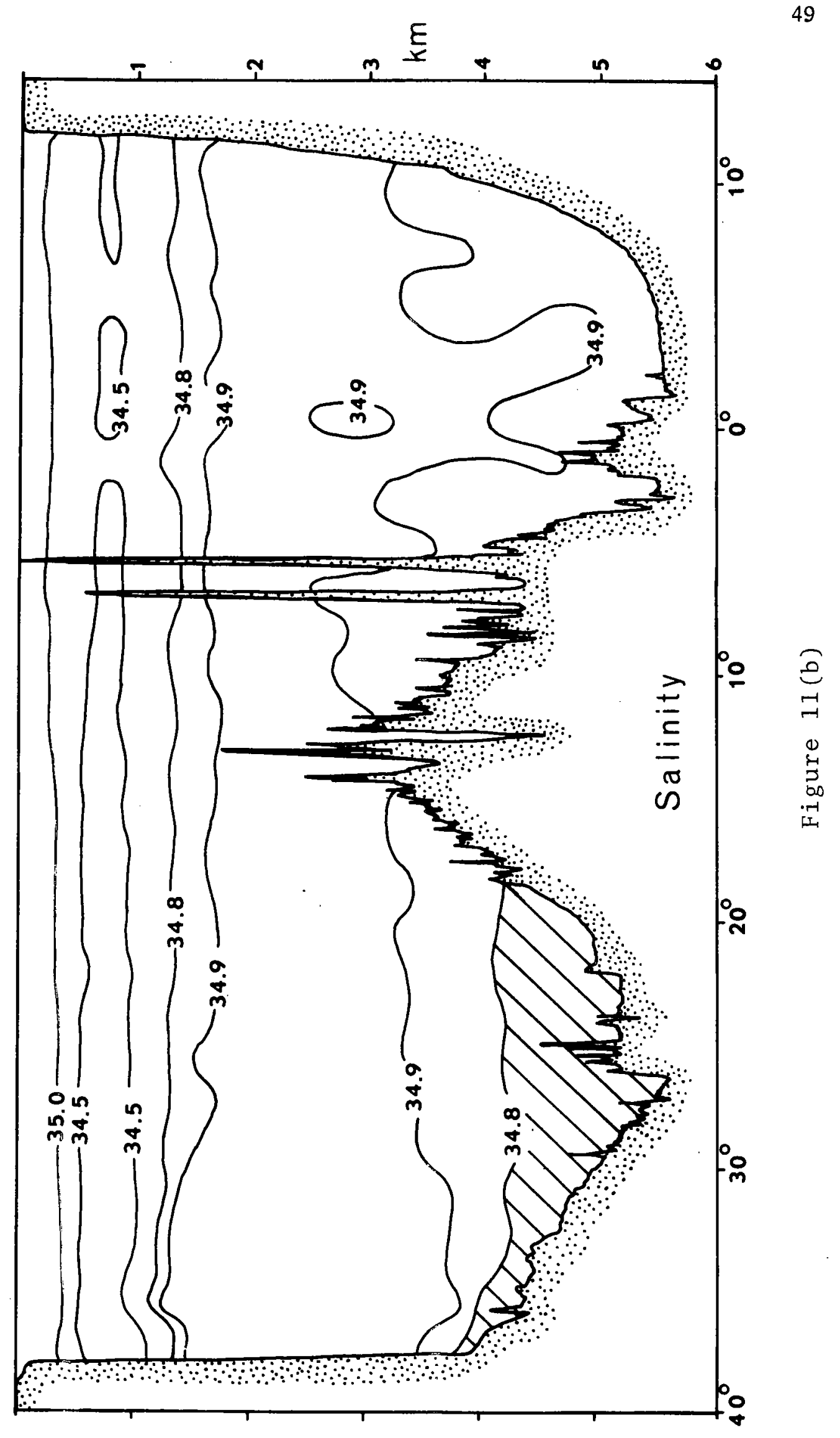



Figure 12. Distribution of potential temperature of bottom water ( > $4000 \mathrm{~m}$ ) in the South Atlantic (after WUst, 1933). Diagonal hatching, indicates water of less than $1.6^{\circ} \mathrm{C}$; horizontal hatching indicates water of greater than $1.6^{\circ} \mathrm{C}$ 



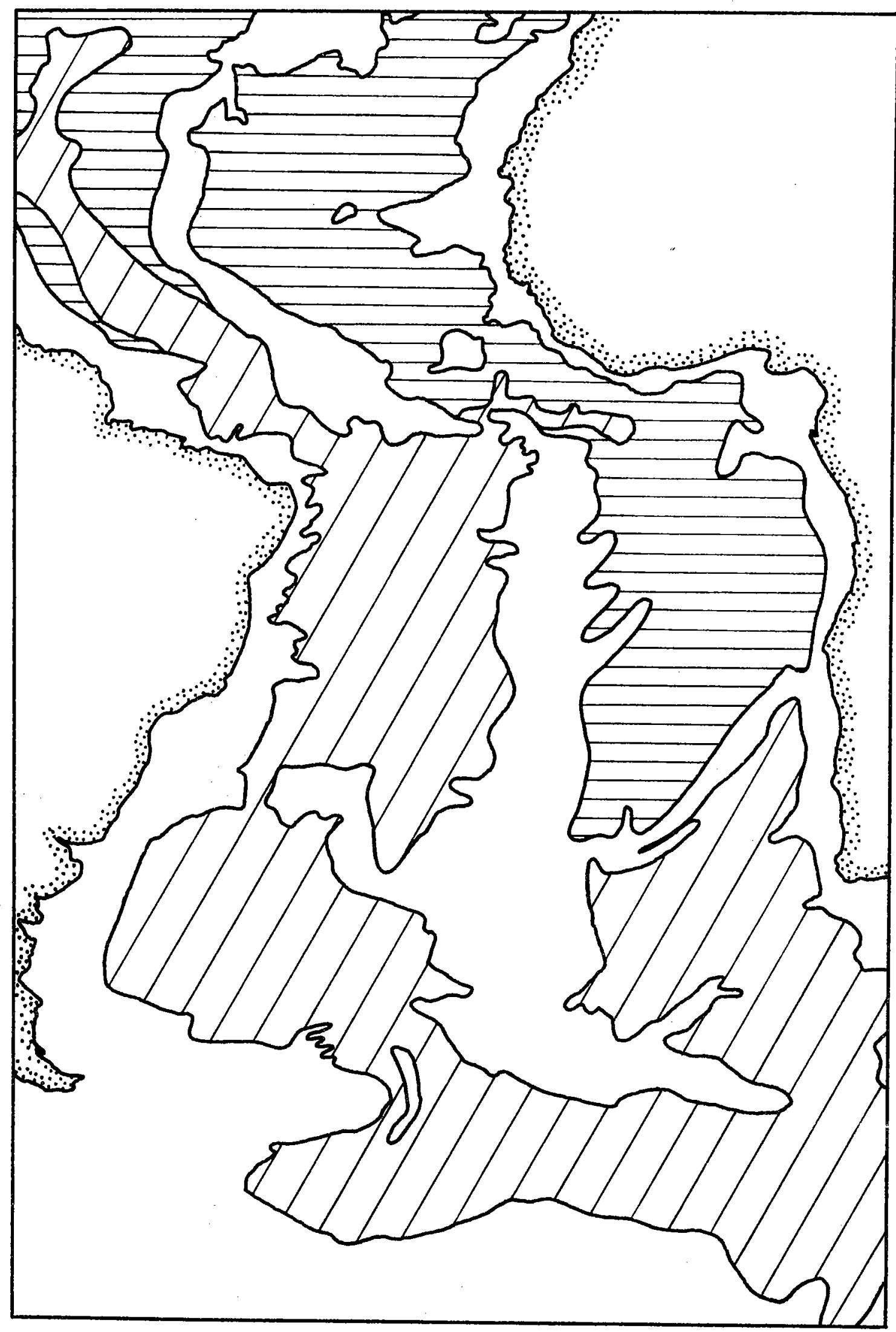

Figure 12 
lower Walvis Ridge seems anomalous. Though they are not as well developed as similar features along the eastern United States, these swe11s may have the same mode of origin, formed by currents flowing along the continental rise. Since present currents do not seem capable of producing such features, it can be assumed: (1) they were not formed by abyssal currents; or, (2) they were formed at a time when abyssal circulation was more vigorous, perhaps during glacial periods of the Quaternary. At present the lack of data does not permit us to choose between these alternatives, though the regularity in size of these features, their position on the rise, and their form tend to argue against another mode of origin, such as slumping or sliding.

\section{Paleoclimatology and Oceanography}

Variations in environmental conditions within the study area during the Quaternary undoubtedly had a significant effect on both the terrigenous and biogenic sources of sediment for the continental margin. Most of the Pleistocene climate research has been conducted in southern and eastern Africa and has been related primarily to the redistribution of early man and other vertebrates in response to climatic changes (e.g., Cooke, 1947; Jones, 1944; Moreau, 1933; Leakey, 1949). Angola, South West Africa, and the western Congo have been very poorly studied, except for a few isolated sites (van Zinderen Bakker, 1963; van Zinderen Bakker and Clark, 1962; Voss, 1970; de P1oey, 1963, 1964, 1965).

Figures 13 and 14 illustrate van Zinderen Bakker's (1967) interpretation of the climatic conditions during glacial intervals. The following are the major differences between glacial and interglacial climatic extremes:

(1) The center of the South Atlantic Anticyclone (high pressure) shifted northwards (by 8 to 12 degrees) and eastward during glacials. 
Figure 13. Schematic interpretation of the climatic features during a glacial southern summer in western Africa (after van Zinderen Bakker, 1967). Horizontal dashed lines indicate pluvial conditions; diagonal lines indicate upwelling. 



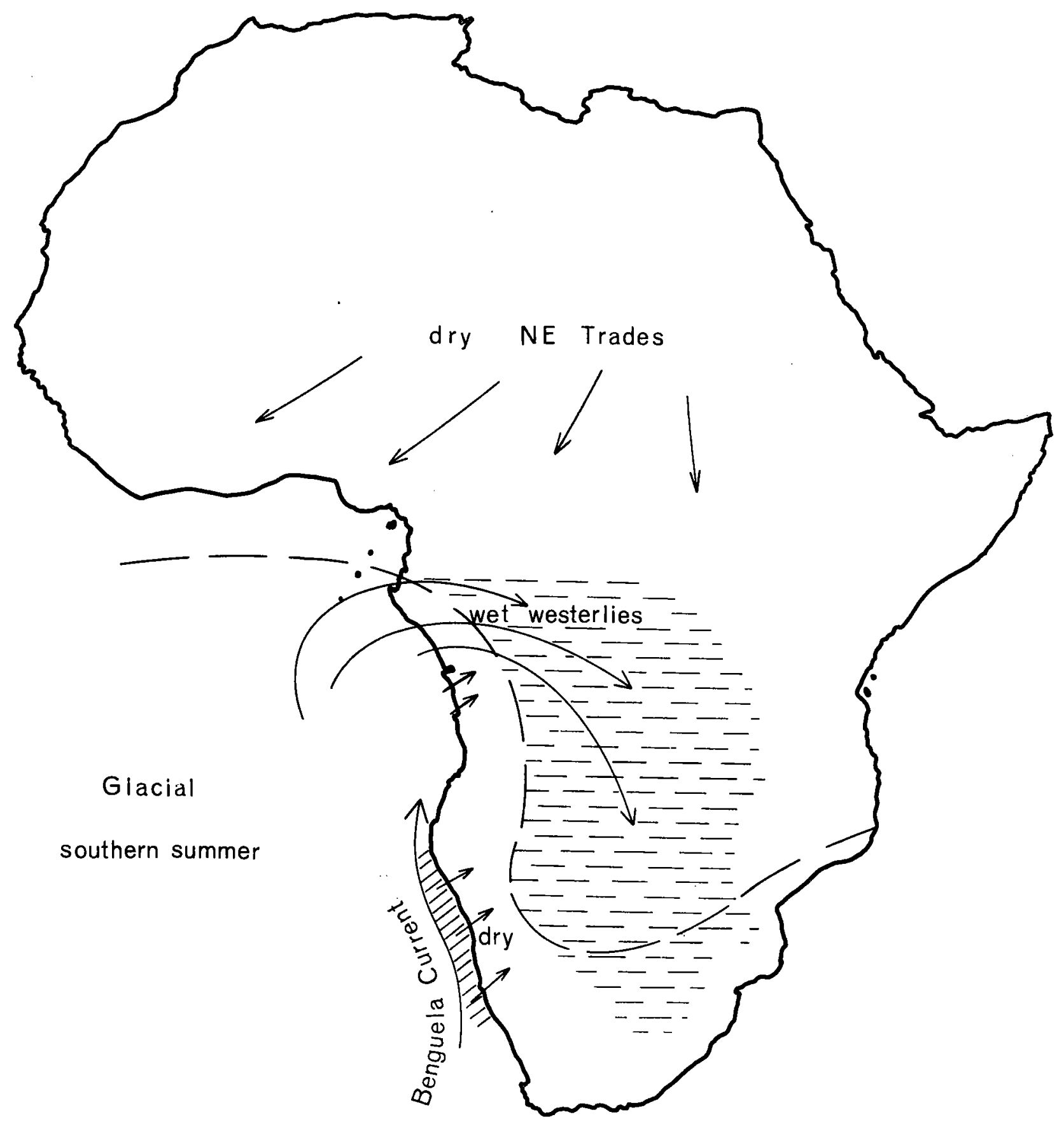

Figure 13 

Figure 14. Schematic interpretation of important climatic features during a glacial northern summer in western Africa (after van Zinderen Bakker, 1967). 


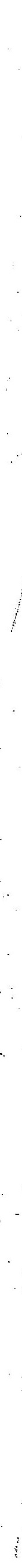




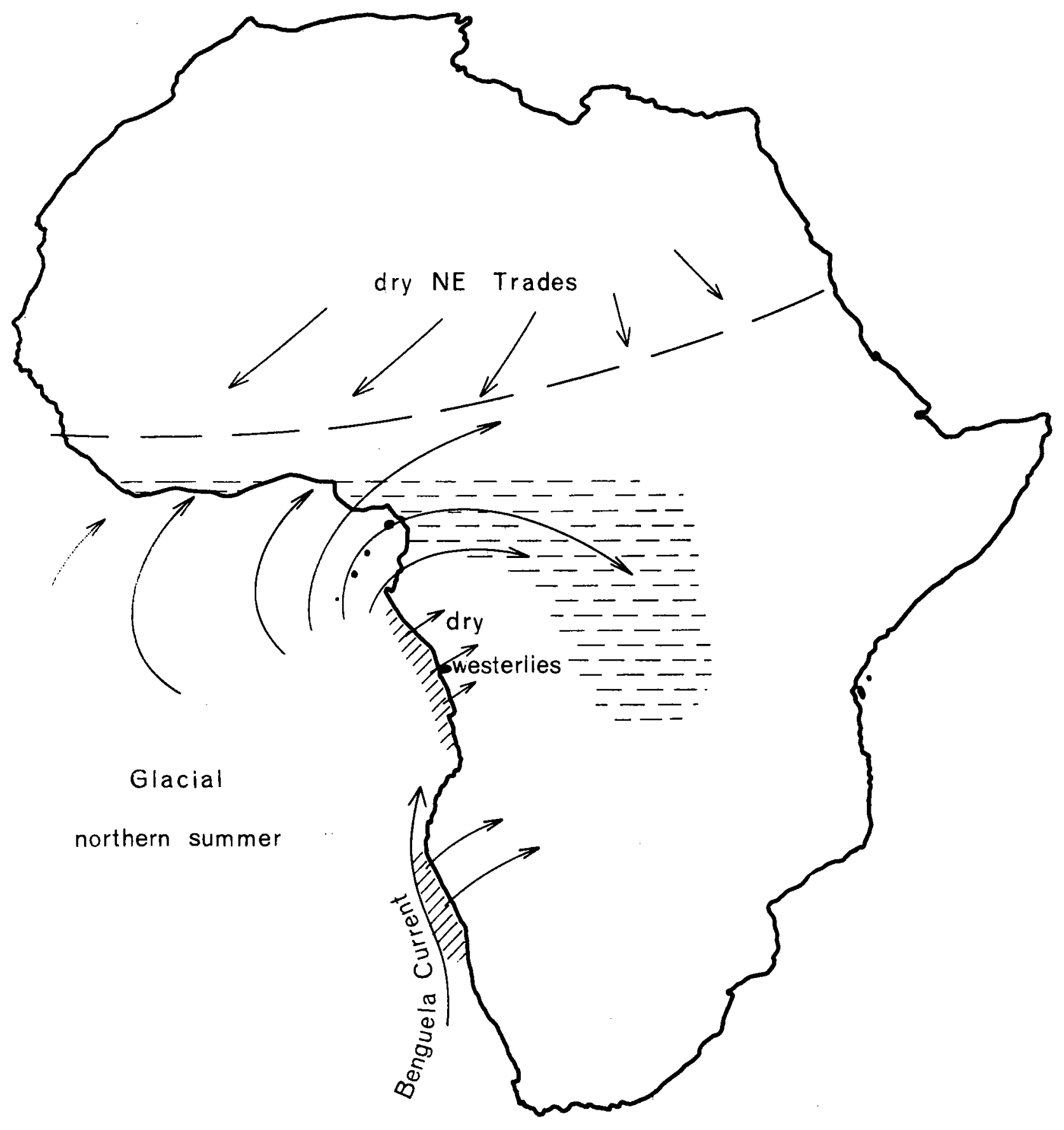

Figure 14 
(2) During glacial summers, pluvial conditions extended southward in the interior from the equator to near the southeast coast of Africa $\left(28^{\circ} \mathrm{S}\right)$. During interglacial summers, pluvial conditions were restricted to the Congo Basin (north of Lat. $10^{\circ} \mathrm{S}$ ).

(3) There was a marked intensification and northward extension of the Benguela Current during the glacial periods. This is indicated by the northward extension of the Namib Desert during glacials. Van Ande1 and Calvert (1971) also suggest that the Benguela Current flowed faster during times of lowered sea level, in order to account for the erosion surfaces they observed along the shelf off South West Africa.

(4) Intensive upwelling, particularly during winter, occurred during glacials off the Congo Republic, Gabon, and northern Angola. This did not occur during interglacials.

The direct correlation between glacial conditions in higher latitudes and pluvial conditions in central Africa has been the focus of several investigations and has generated considerable controversy (van Zinderen Bakker, 1966; F1int, 1959). Based on a wide variety of evidence from sites throughout subSaharan Africa, van Zinderen Bakker (1972) concludes:

(1) temperature changes coincident with those of the northern hemisphere a1so occurred in tropical Africa;

(2) changes in humidity were correlated with temperature changes; and,

(3) the "glacial" climate of tropical Africa was drier and the "interglacial" climate wetter than at present.

As van Zinderen Bakker points out, however, this relationship does not apply to extratropical regions. 
Glacial aridity in this region was probably further intensified along the Angola and Congo coastal areas by the more northward penetration of the Benguela Current and the onset of upwelling conditions along suitably aligned coastal regions between Luanda and Cape Lopez. According to van Zinderen Bakker (1967), supported by the work of de Ploey (1963) and Clark (1962), there was a "desert climate along the coast and a semiarid region reached farther inland, reaching as far as Leopoldville (400 km inland)." These semiarid conditions also would have reached as far as central Angola, giving it a semiarid, cool climate during glacial periods. Fairbridge's (1964) studies on the distribution of fossil dunes in central Africa also support this conclusion. The dry conditions undoubtedly had a significant effect on the hydrologic regime of the Congo River, the single most important source of terrigenous sediment for the Angola Basin. This is perhaps of even greater relevance since most of the sediment delivered to the ocean is derived from runoff below Stanley Pool (Heezen et a1., 1964), a region that was desert or semi-desert during glacial periods.

Data from earlier than approximately 65,000 years B.P. are completely lacking for this region of Africa. In addition, no attempts have been made to determine the precise temperature and rainfall changes that took place between glacial and interglacial periods, though van Zinderen Bakker and Clark (1962) and van Zinderen Bakker and Coetzee (1972) suggest that the region in northeastern Angola experienced temperatures equivalent to at least $500 \mathrm{~m}$ greater altitude during the period between 30,000 and 14,000 years B.P. This was followed by a warmer, humid phase (the Makalian Wet Phase) during which a climatic optimum was reached (approximately 7,000 to 4,500 years B.P.). 


\section{DISTRIBUTION OF SUSPENDED MATTER}

\section{Surface Suspended Matter}

\section{Suspended Matter Distribution}

Throughout the WAIDA expedition and the "Atlantis II" Cruise 67 surface suspended matter samples were taken in an effort to determine the pattern of dispersal of fine sediment in the surface waters off the west coast of Africa. In addition, Forel color determinations were made during daylight hours and clay mineral determinations were made on selected samples collected on silver filters. Temperature and salinity were also recorded when samples were taken.

The results from the "At lantis II" cruise have been reported by Emery et a1. (1973). The combined results from the French and American cruises for suspended matter concentration (Figure 15) show several significant features:

(1) the broad band of high sediment concentration off South West Africa and southern Angola;

(2) the high concentrations off major rivers, such as the Kunene, Cuanza, and Congo; concentrations 150-200 kilometers from the mouth of the Congo River may exceed $1.0 \mathrm{mg} / 1$;

(3) the large offshore area with very low (less than $0.12 \mathrm{mg} / 1$ ) concentrations between Lat. $7^{\circ} \mathrm{S}$ and $10^{\circ} \mathrm{S}$.

The plume of high sediment concentration from the Congo closely parallels the salinity distribution (Figure 10). Within the low salinity region off the Congo, the "Atlantis II" results were consistently lower than the WALDA results (Figure 16), although they converged at salinities above 35\%. These discrepancies were apparently not the result of a systematic analytical error since the "Atlantis II" results off southern Angola were consistently higher than the WALDA data, and elsewhere were quite compatible. Rather, this dif- 
Figure 15. Distribution of total suspended matter (mg/1.) off southwestern Africa based on samples collected from the N/O "Jean Charcot" during the WALDA expedition of 1971 and from the R/V "Atlantis II" during the Eastern Atlantic Continental Margin Study of 1972. Solid points are locations of deep-water stations. 



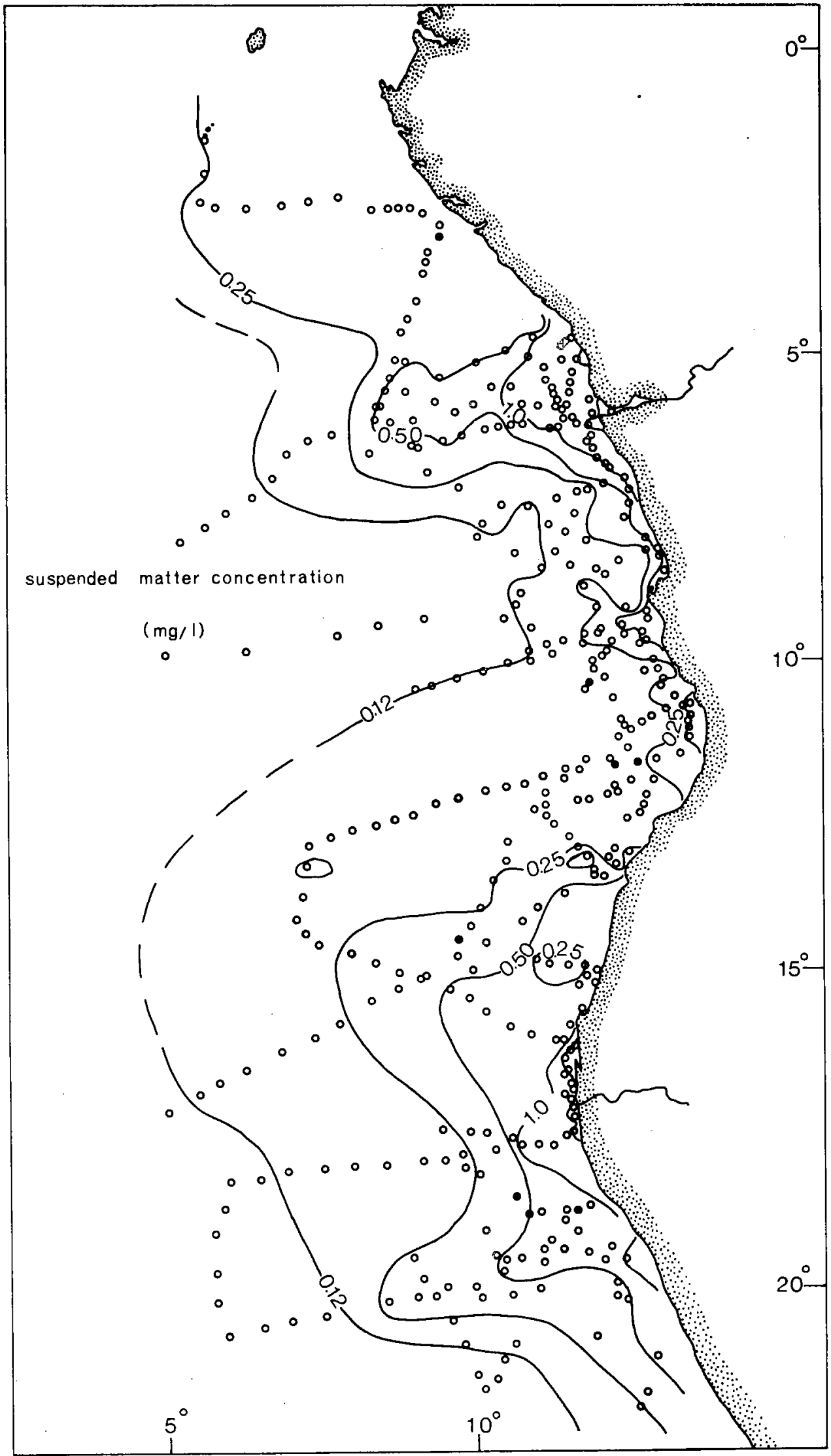

Figure 15 
Figure 16. Relationship between salinity and tota1 suspended sediment concentration off the Congo River based on data from the "At lantis II" ( $O$ ) and the "Jean Charcot" ( $O)$. 



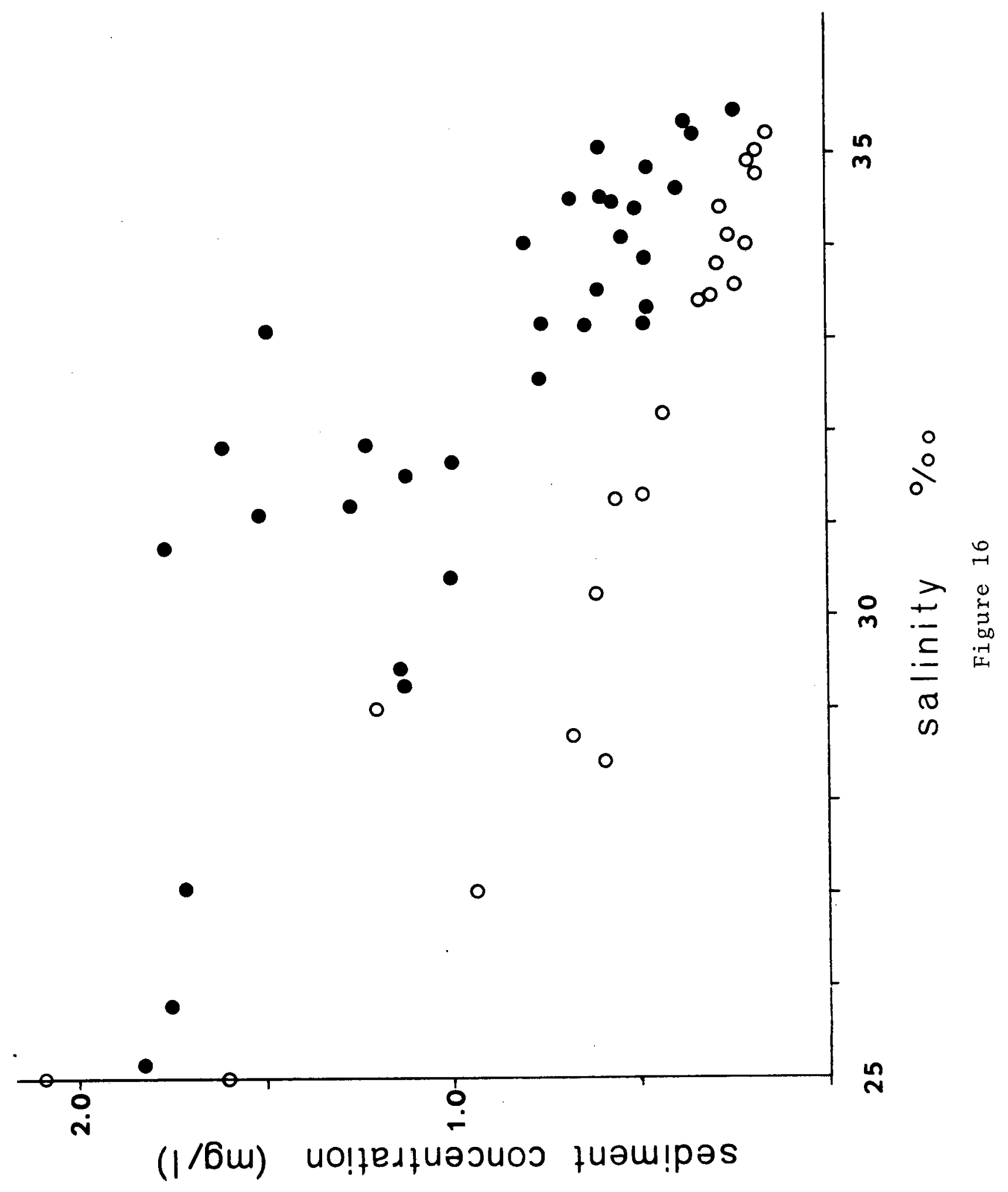


ference probably reflects that change in river discharge between June and July, the times of the two cruises. On the average, approximately $5 \times 10^{3}$ $\mathrm{m}^{3} / \mathrm{sec}$ more water is discharged in June than in July (Donguy et a1., 1965). One possible explanation for these differences is that during periods of high river discharge, the distance from the river mouth to a particular isohaline is greater than at times of lowered discharge. This increased distance may permit more suspended matter to leave the surface waters and to sink towards the bottom than would occur during periods of lower flow rate. This would be particularly true if the sediment-discharge relationship were found to be a convex-upward curve; as pointed out by Bornhold et al. (1973), considerably more detailed studies are needed to establish the exact mechanisms controlling the dispersal of fine sediment into the ocean from major rivers.

The high suspended matter concentrations off South West Africa and southern Angola are directly related to the Benguela Current and the high biological productivity associated with it (Steeman Nielsen and Jensen, 1957). Combustible organic matter concentrations exceed $0.25 \mathrm{mg} / 1$ in a band several hundred kilometers wide along the coast south of $14^{\circ} \mathrm{S}$ (Emery et al., 1973). In addition, organic concentrations are high off major rivers such as the Congo and Kunene; much of this organic material probably is derived from the continent, as evidenced by the frequent observation of roots and branches of trees offshore from these rivers. In addition, however, much of the measured organic matter off major rivers probably results from increased phytoplankton productivity produced by the high nutrient concentrations in the river waters. The suspended matter distribution off central Angola, Congo, and Gabon is closely related to the circulation scheme proposed by Moroshkin et al. (1970). The zone of low sediment concentration off central Angola corresponds to the eastward influx of water originating in the South Equatorial Counter- 
current. The path of Congo River water as it enters the Atlantic is also controlled by the bifurcation of the South Equatorial Countercurrent as it approaches the coast (Figure 9). Further north, suspended matter from the shelf off Gabon is carried northward into the Gulf of Guinea (Bornhold et al. , 1973).

The results of Forel color determinations (Figures 17 and 18) closely parallel the total sediment concentration, as do Secchi disc transparency results (Figure 19) (Emery et al., 1969; Manheim et al., 1970; Bornhold et a1., 1973).

Composition of Suspended Matter

X-ray diffraction studies of 21 suspended matter samples collected on silver filters revealed significant latitudinal differences in the importance of particular clay minerals. Off southern Angola and South West Africa, montmorillonite is dominant with lesser amounts of illite and kaolinite. North of central Angola, however, montmorillonite is much less abundant and the clay-mineral assemblage is dominated by kaolinite. This is particularly evident within the plume of river water from the Congo where kaolinite is extremely abundant. Talc was present in all of the samples analyzed; this mineral has also been noted in other studies of suspended matter in open ocean waters (Emery et al., in press; Summerhayes, personal communication). Chlorite was detected in only a few of the samples.

Twenty sections of Millipore filters of suspended matter were mounted in cedar oil and viewed under a petrographic microscope. Commonly observed constituents included: diatoms, radiolaria, sllicoflagellates, dinoflagellates, marine algae, fecal pellets, organic aggregates, and inorganic grains.

Fecal pellets (Figure 20) were elongated, ova1, dense aggregates of 

Figure 17. . Distribution of Fore1 color (\% ye11ow) of the sea surface based on the combined data from the "Jean Charcot" and the "Atlantis II". 

67

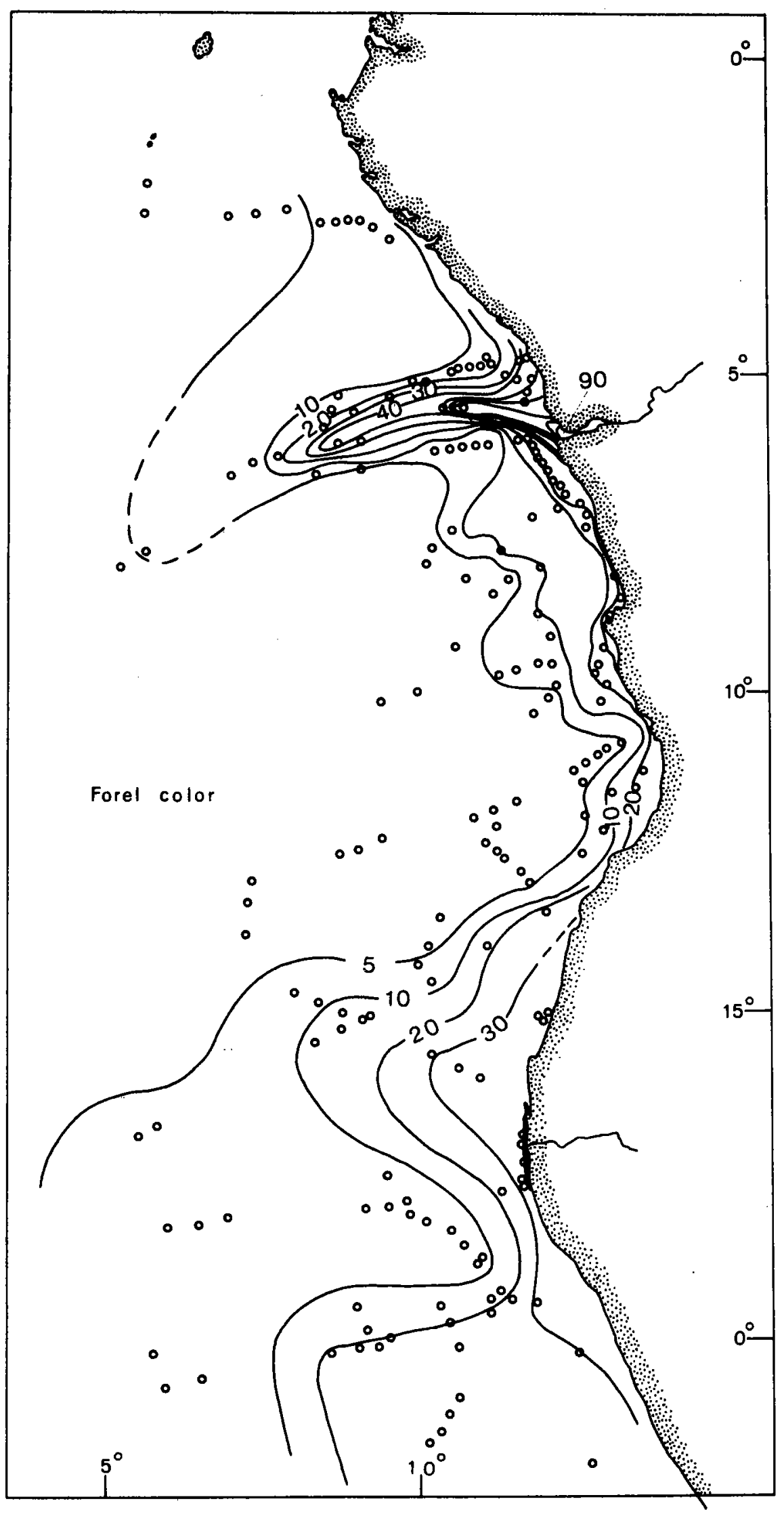

Figure 17 
Figure 18. Relationship between Forel color and suspended matter concentration in surface waters over the eastern Angola Basin based on data from the "Jean Charcot" ( $O$ ) and the"Atlantis II" ( $)$. 



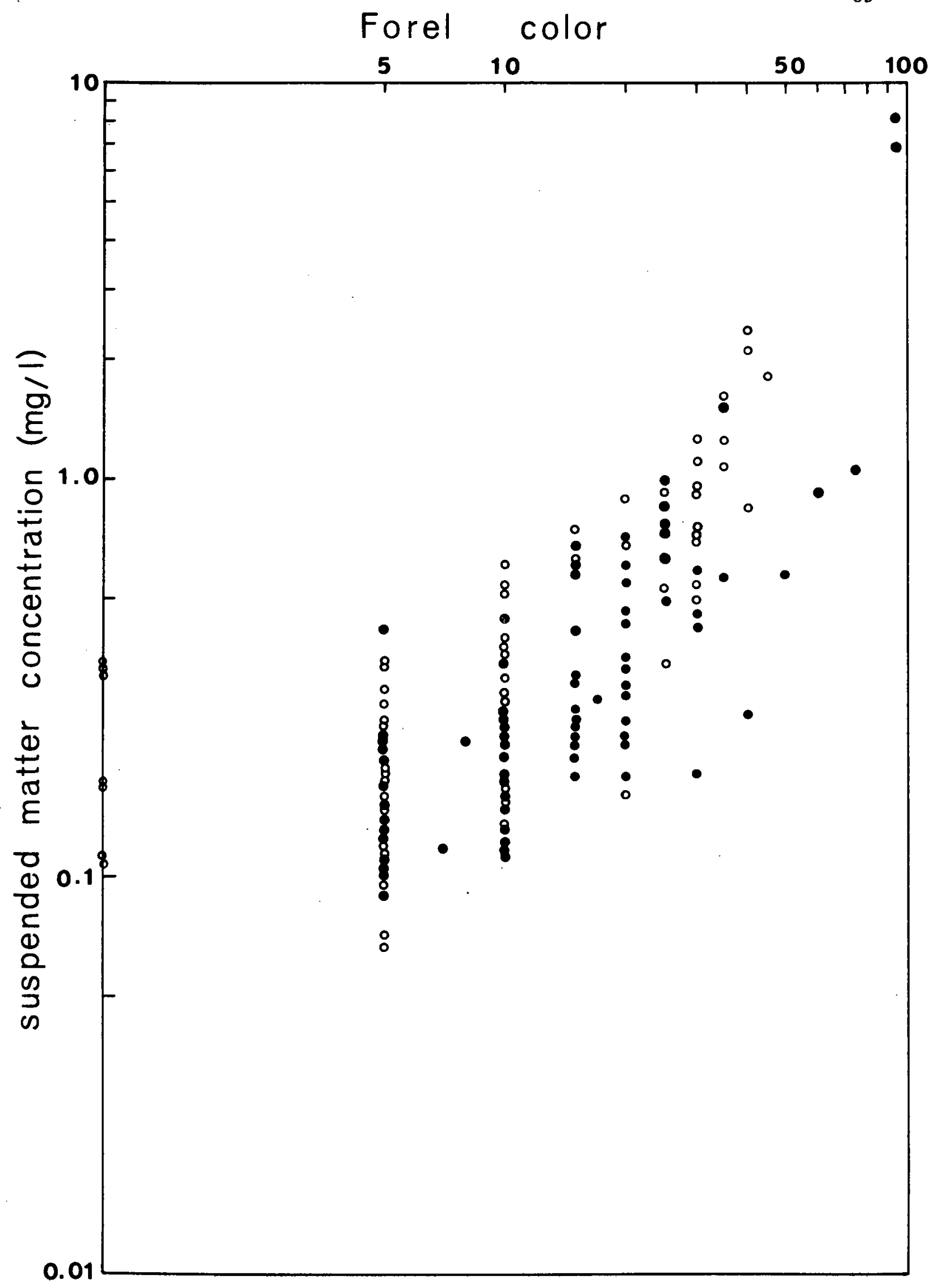

Figure 18 
Figure 19. Distribution of Secchi disk transparency based on Capart (1951) and Gallardc et a1. (1969). 


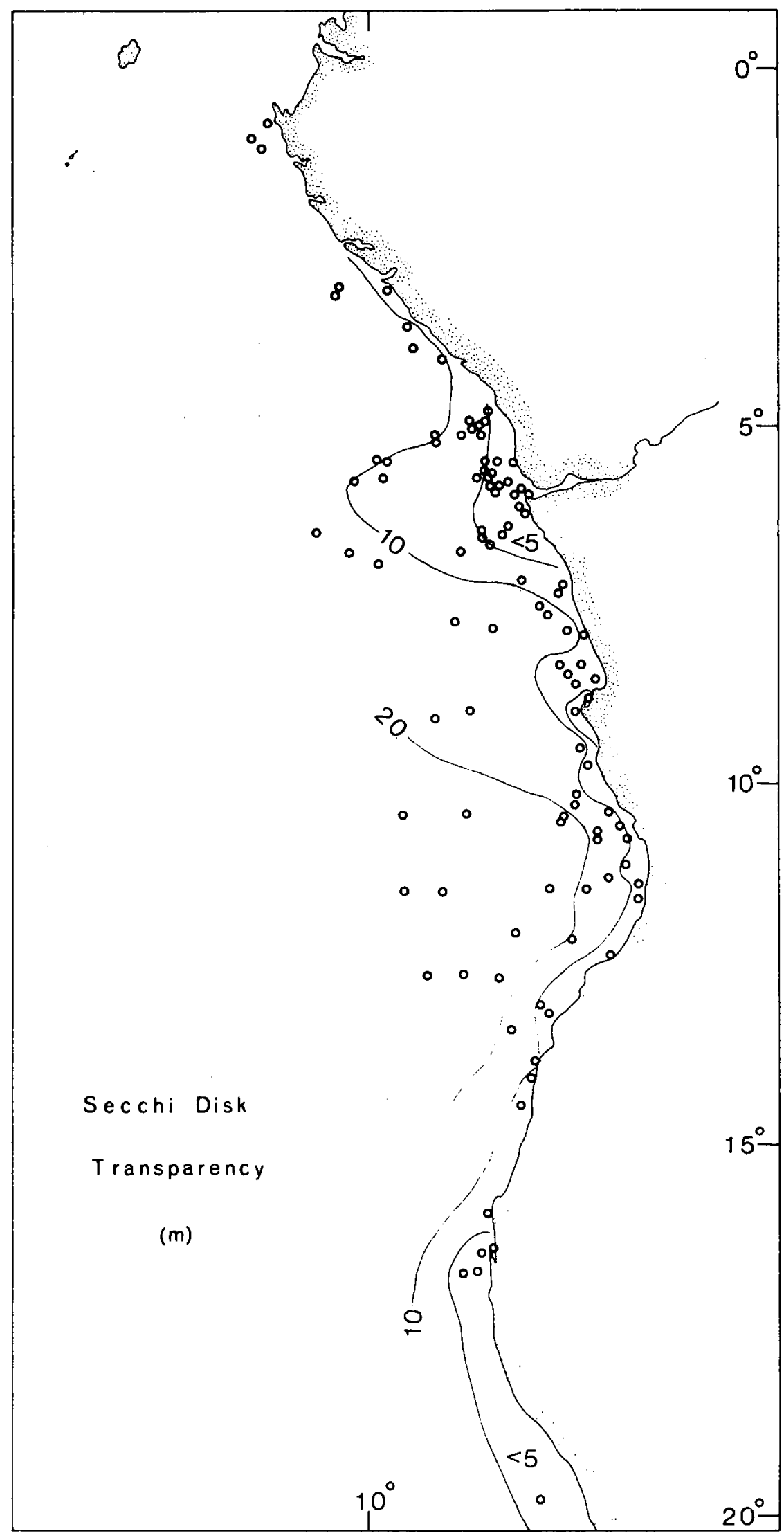

Figure 19 
Figure 20. Photomicrograph of a fecal pellet in a suspended matter sample off Angola. Scale bar represents $50 \mu$. 


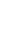




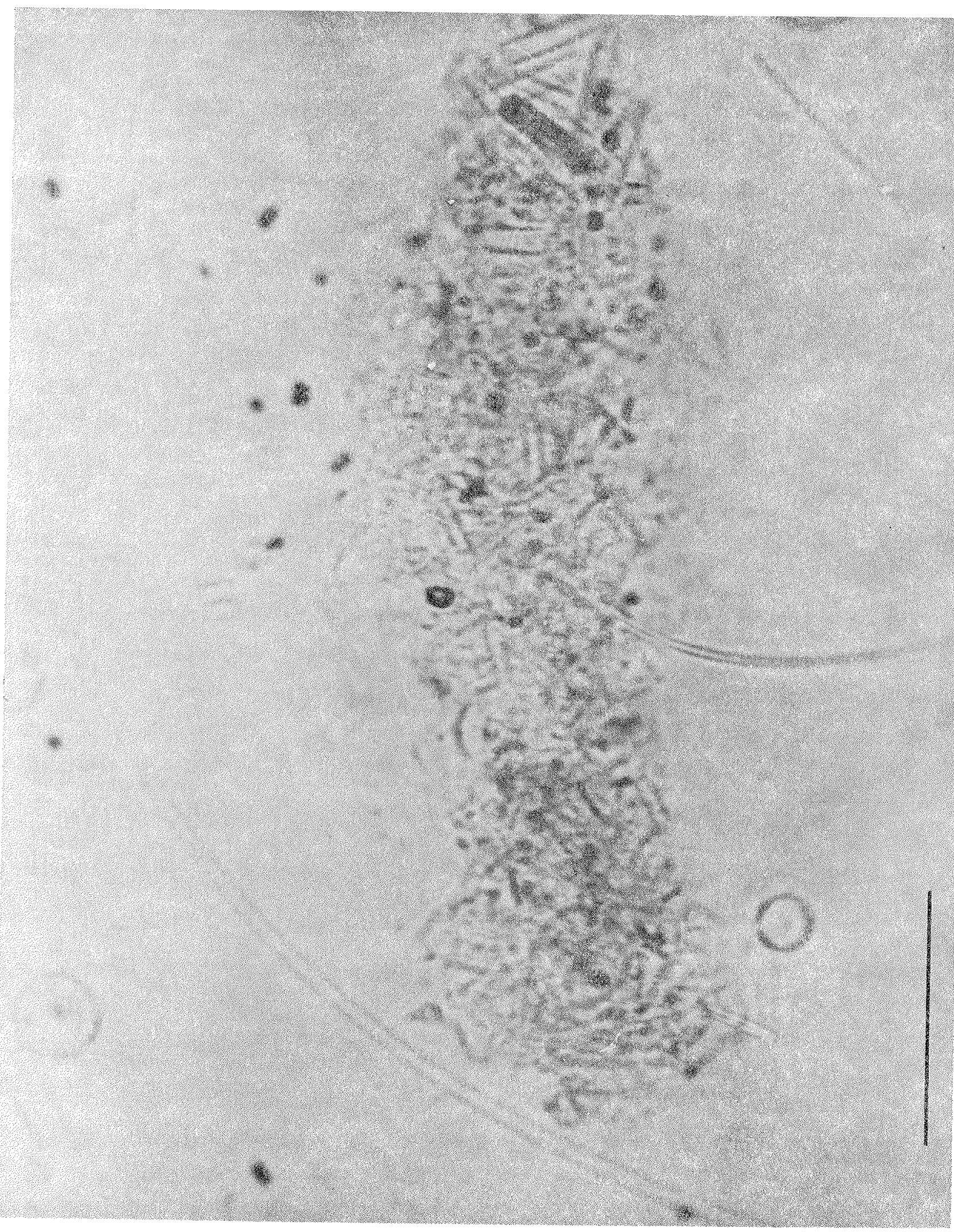

0
0
0
0
0
0
$0-1$
$I_{1}$ 
Figure 21. Photomicrograph of an organic aggregate in a suspended matter sample off Angola. Scale bar represents $50 \mu$. 



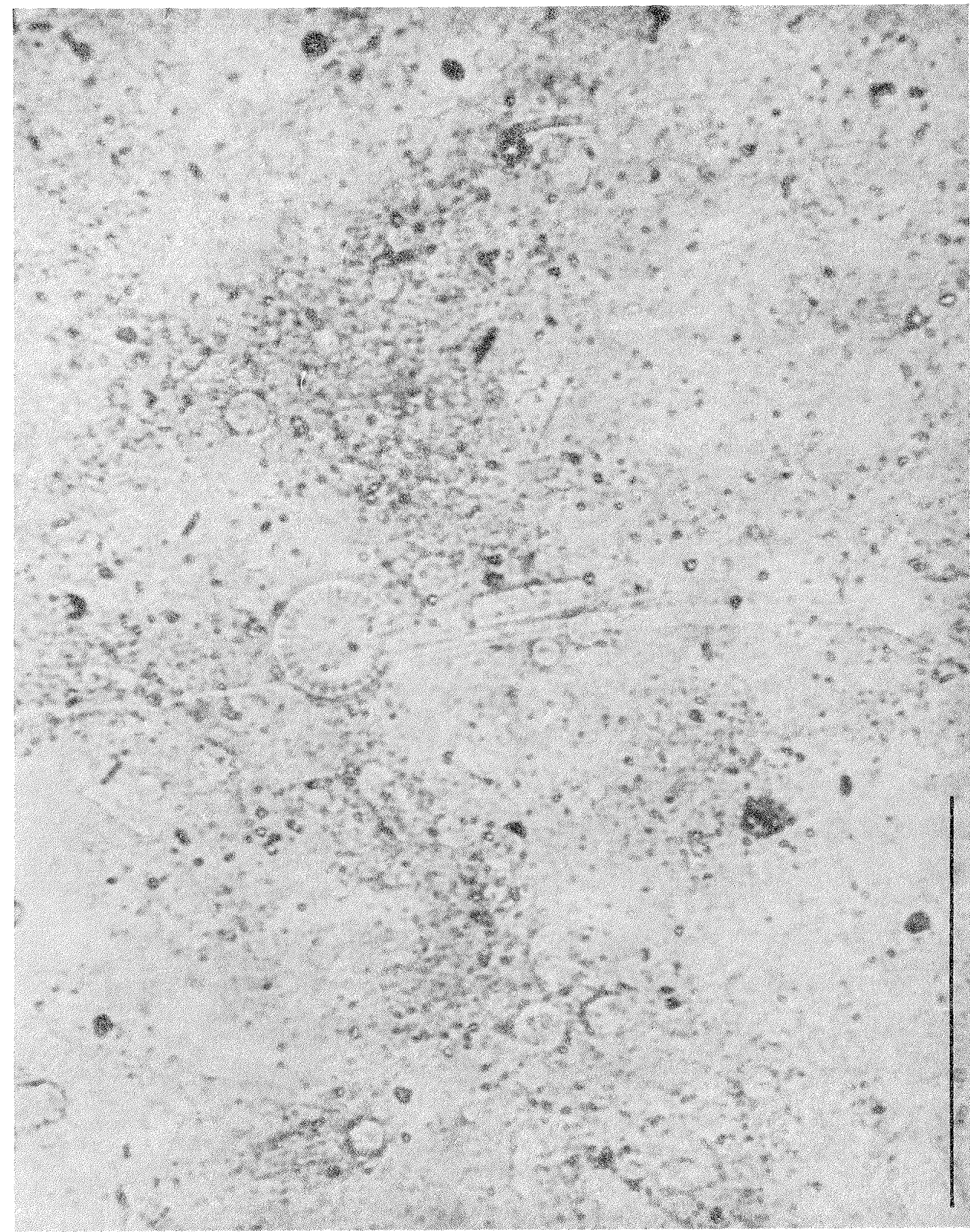


diatom debris and organic matter. Organic aggregates were, by contrast, more diffuse "mats" of organic matter with diatoms and inorganic debris adhered to the surface (Figure 21).

Considerable latitudinal variation is apparent in the density and diversity of diatoms and other components. Silicoflagellates and dinoflagellates are particularly abundant in the southern part of the area (south of Lat. $10^{\circ} \mathrm{S}$ ). Diatoms reach their highest diversity in the southernmost part of the region (south of Lat. $15^{\circ} \mathrm{S}$ ) and in samples off the Congo River mouth; between about Lat. $8^{\circ}$ and $15^{\circ} \mathrm{S}$ very impoverished diatom floras are found. Fecal pellets and organic aggregates follow the same trend as diatoms, with the latter being very abundant off the Congo River mouth.

\section{Suspended Matter in the Deep Water}

In addition to surface water data, ten stations (Figure 15) were occupied during the WALDA expedition where suspended matter concentrations were measured on the near-bottom water off the Angola Basin. These samples were taken with either a 30-1iter Niskin bottle or two van Dorn samplers placed approximately 10-15 meters above a bottom camera. Because of the very precise way in which the camera was maintained at or near the bottom, it was felt that very little sediment was roiled into suspension by the camera frame.

The near-bottom suspended matter concentrations in the Angola Basin exhibit a linear decrease with depth below 1000 meters (Figure 22a). Three stations (filter numbers 129, 130, and 160), which show distinctly lower values, were taken within the rough topography of the Angola diapir field. The topography of the Angola diapir field protects the near-bottom water from the lateral transport of suspended matter (possible originating from the Congo River as suggested by Connary and Ewing, 1972). The uniformly linear 
Figure 22. (a) relationship between suspended matter in near-bottom water and water depth for eight stations off Angola occupied during the WALDA expedition.

(b) relationship between light scattering (E) and water depth for deep nephelometer stations in the Angola Basin (based on data in Connary and Ewing, 1972). 


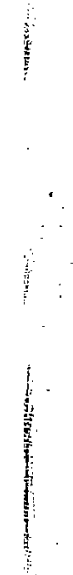




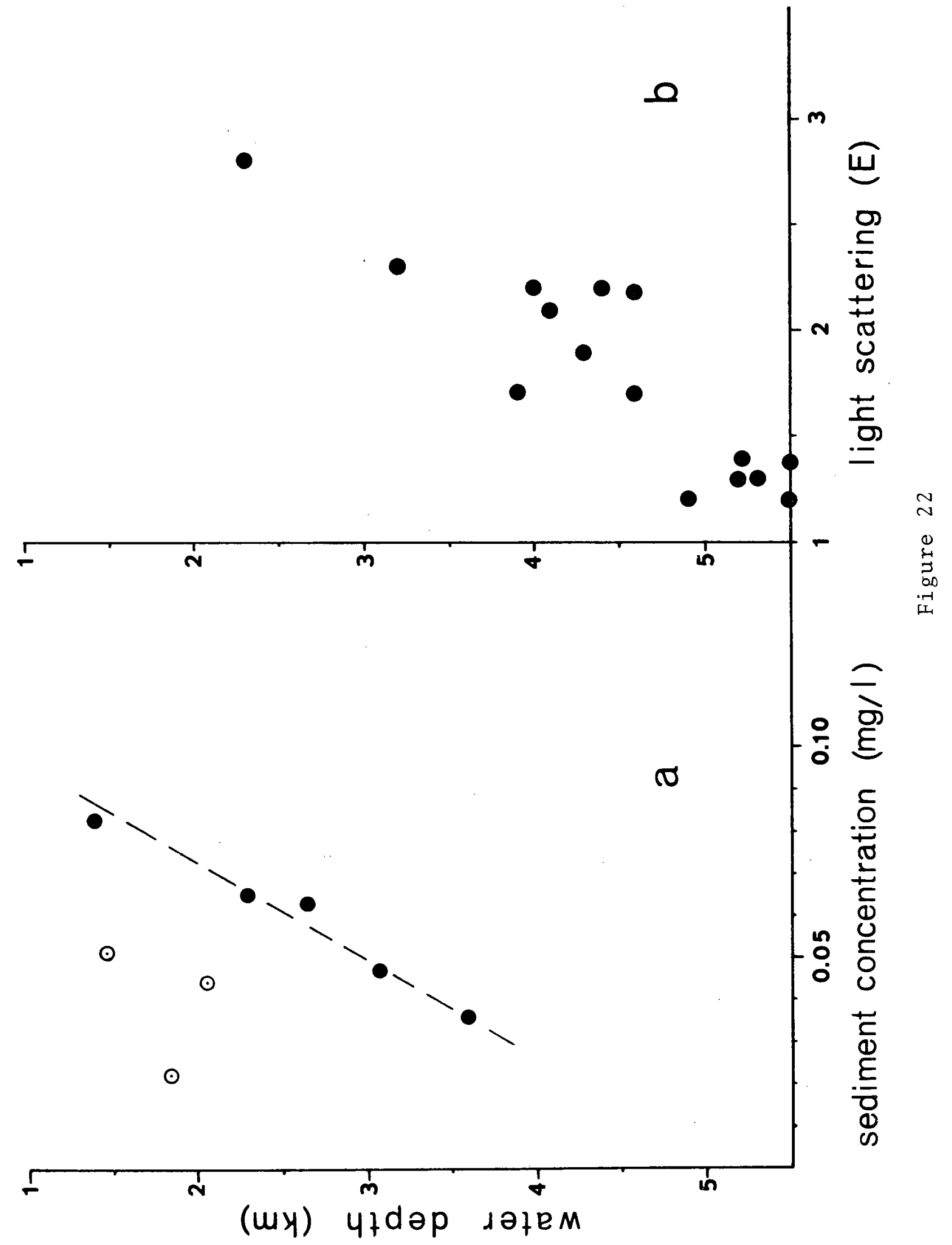


decrease in sediment concentration for the other flve station, and the absence of any major discontinuitfes, also suggests that no wel1-developed nepheloid layers exist at depths down to $3600 \mathrm{~m}$. Variations in light scattering values with depth closely parallel the observed trend in sediment concentration from the present study (Figure 226). Connary and Ewing (1972) state that intermediate nepheloid layers (less than $4000 \mathrm{~m}$ ) are only of local extent. The main nepheloid layer occuples the homogenous water mass below about 4000-4500 meters. 
RECENT SEDIMENTS

Surface sediments from the continental shelf, slope, rise, and abyssal plain were analyzed for texture, percent calcium carbonate, clay minerals, and organic carbon in an effort to determine the nature of sedimentation during the Holocene in the eastern Angola Basin. The samples were also studied under a binocular microscope and the abundances of the major components were noted. The results of the analyses of surface sediments are found in Appendix II. The methods used in the analyses are outlined in detail in Appendix III.

\section{Surface Distribution of Calcium Carbonate}

Calcium carbonate content of surface sediments varies considerably throughout the study area (Figure 23). Continental shelf sediments off Gabon, Congo, and Angola are characterized by carbonate values of less than $20 \%$. Sample density is too scattered in most areas to detect any trends among these samples, although inner shelf samples appear to contain, in general, less than $10 \% \mathrm{CaCO}_{3}$, whereas outer shelf samples contain between 10 and $20 \%$. Carbonate values on the continental rise off central Angola are approximately $25-45 \%$, diminishing seaward to less than $20 \%$. This seaward diminution is primarily controlled by the increasing carbonate dissolution with depth below $5000 \mathrm{~m}$ as evidenced by the corroded appearance of foraminiferal tests. The Congo Cone is characterized by carbonate values of less than $15 \%$ as a result of the tremendous influx of terrigenous sediment through the Congo canyon system. The sediments on the Walvis Ridge and Guinea Rise contain more than $80 \%$ carbonate. The Walvis Ridge, isolated from major terrigenous sediment sources, is dominated by biogenic sediments, as is the Guinea Rise, located 

Figure 23. Distribution of calcium carbonate in surface sediments from the eastern Angola Basin and adjacent areas. 



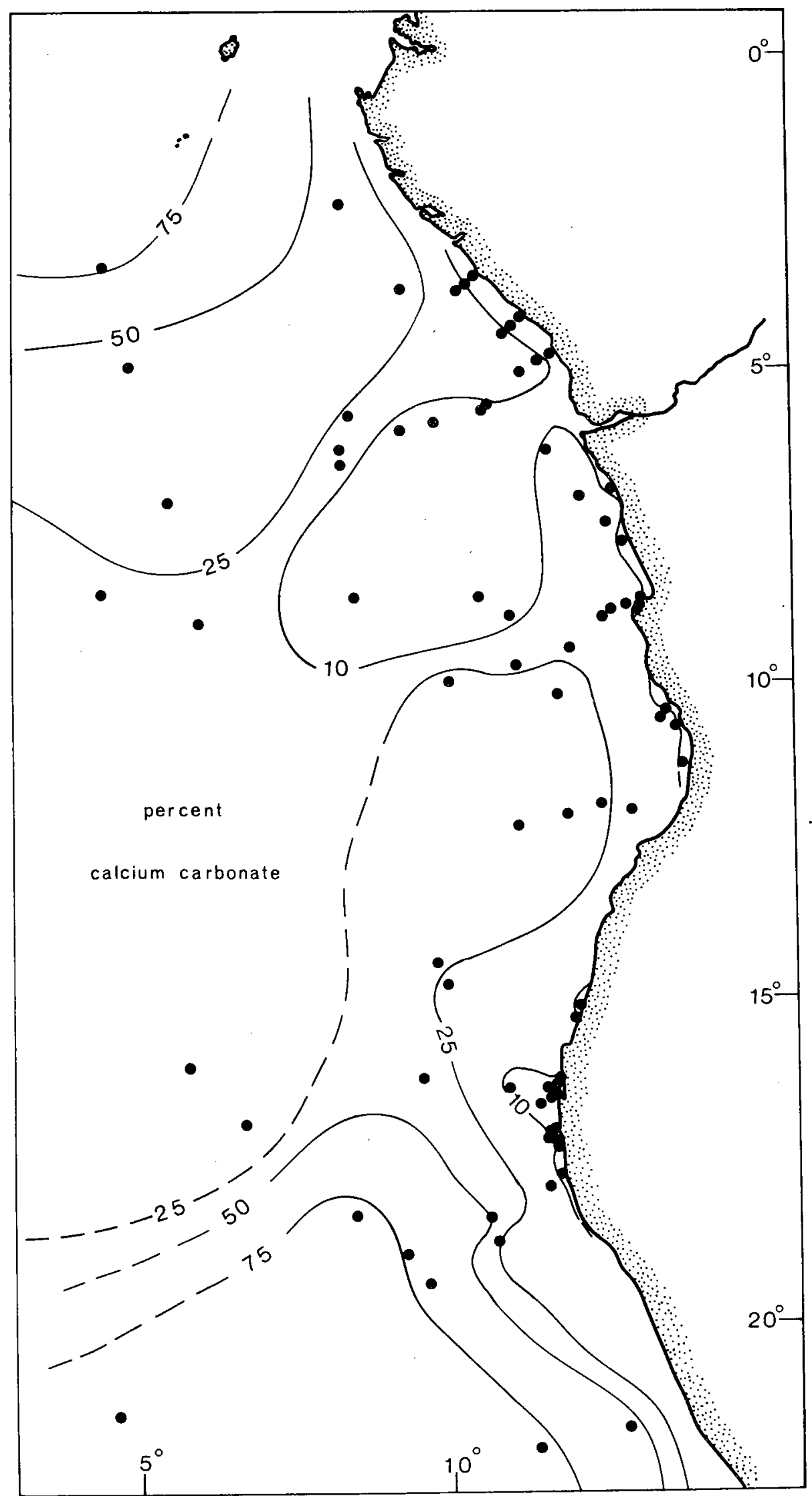

Figure 23 
in a region of high surface carbonate productivity.

\section{C1ay Minera1s}

An investigation of the clay-mineral composition of Angola Basin sediments was undertaken in order to: (1) attempt to define the present clay-mineral provinces; and, (2) attempt to describe the changes in claymineral abundances throughout the late Pleistocene and Holocene.

\section{Methods}

The less-than-2-micron fraction was separated by centrifugation, sedimented on a silver filter (Selas Flotronics; $0.45 \mu$ nominal pore size), and scanned at $2 \%$ minute on a Norelco $x$-ray diffractometer (nickel filter, $\mathrm{Cu} \mathrm{K} \propto$, $40 \mathrm{Kv}, 40 \mathrm{ma})$. The sample was then glycolated by the vapor pressure technique and scanned again. Some samples were then heated to $400^{\circ}$ and $500^{\circ} \mathrm{C}$ and reanalyzed.

The method for determining mineral percentages is based on weighted peak area and is summarized by Biscaye (1965). This method was selected primarily for comparison purposes: Biscaye is the only other worker to have analyzed the deep-sea clay-mineral composition of sediments in this region of the South Atlantic. As Biscaye (1965) pointed out, however, "the weighted peakarea percentages... are constructs and, at best, are untestable approximations of real percentages."

The following clay minerals were identified in this study: montmorillonite, kaolinite, illite, and chlorite. Chlorite and kaolinite were estimated using the $3.58 \AA / 3.54 \AA$ doublet, following Biscaye's (1964) method. The crystallinity $(\mathrm{v} / \mathrm{p})$ of montmorillonite was also calculated; this is the ratio of the low ang1e "valley depth" to the peak height of the $17 \AA$ glycolated 
montmorillonite peak.

\section{Chlorite}

Chlorite concentration is uniformly low at mid-low latitudes and on $1 \mathrm{y}$ gains relative importance (greater than 10\%) at higher 1atitudes (Goldberg and Griffin, 1964; Biscaye, 1965). Within the study area, chlorite was consistently less than $5 \%$ of the total clay fraction. This value agrees with Biscaye, but is under the 10-15\% range determined by Goldberg and Griffin (1964).

\section{Montmorillonite}

Goldberg and Griffin (1964) stated that montmorillonite distribution is generally related to sea-floor volcanism. Biscaye (1965), on the other hand, discounted any clear association between volcanism and montmorillonite abundance and concluded that any relation between this clay mineral and latitude or source is obscured by the fact that it can be formed under a wide variety of conditions, both subaerial and submarine. Studies of atmospheric dust by Chester et $\underline{\text { al }}$. (1972) in the southeastern Atlantic show a very complicated latitudinal distribution pattern for montmorillonite.

The observations of Biscaye (1965) are clearly supported by the present study (Figure 24). Montmorillonite varies, in general, between 30 and $60 \%$. A notable exception occurs in the vicinity of the Congo and Kunene Rivers, where dilution by kaolinite and illite reduces montmorillonite concentrations to less than $20 \%$.

A11 of the values of crystallinity except two are positive and average about 0.30 , with some as high as 0.74 . The values display no systematic variation within the study area, although a slight trend toward low values in the northernmost part of the region tends to support Biscaye's conclusion 

Figure 24. Distribution of montmorillonite in surface sediments of the eastern Angola Basin. 



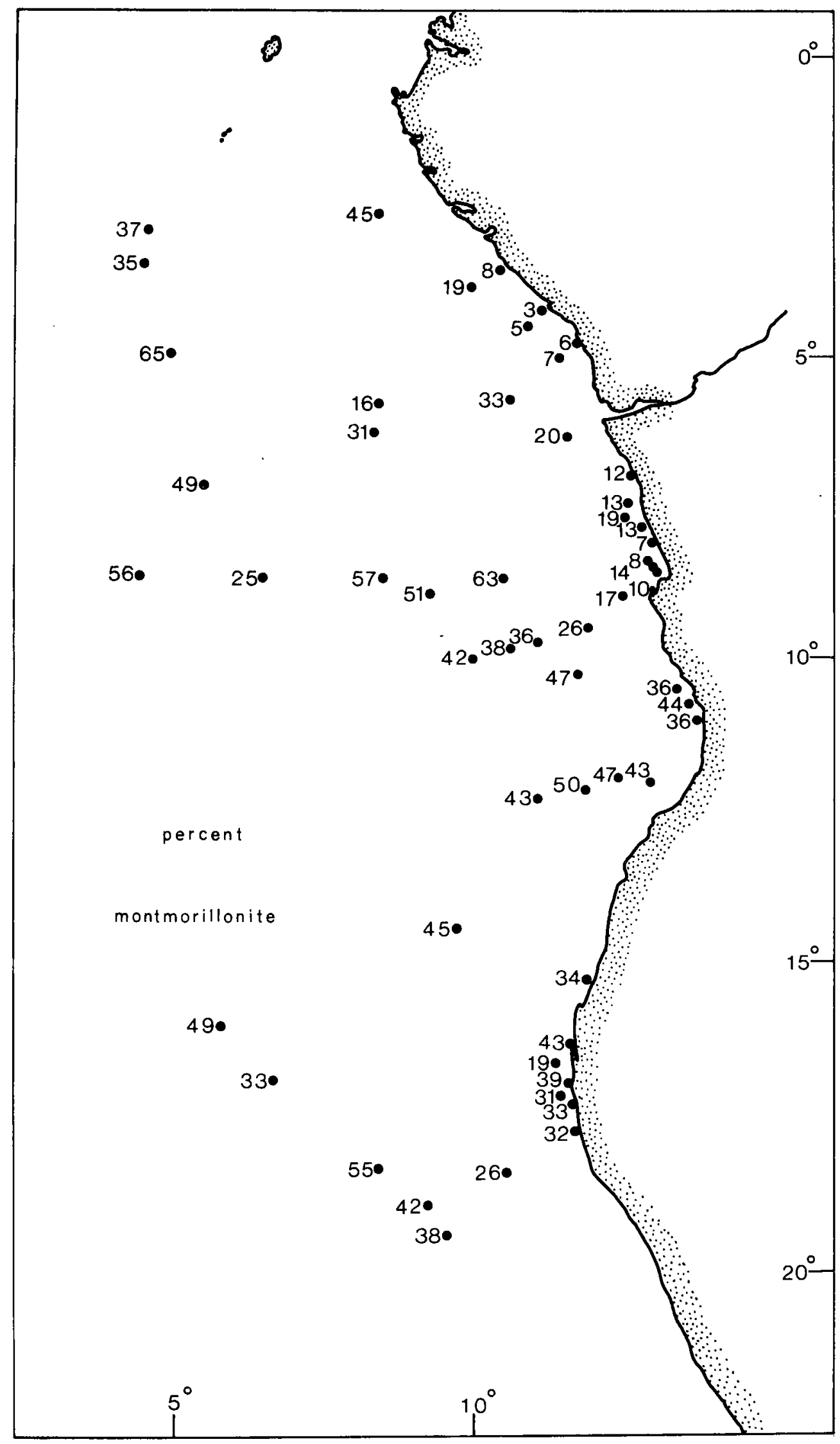

Figure 24 
that tropical weathering is not conducive to well-developed crystallinity in montmorillonite.

\section{Kaolinite}

Kaolinite abundance corresponds directly to the intensity of tropical weathering on adjacent land masses (Yeroshev-shak, 1961; Goldberg and Griffin, 1964; Biscaye, 1965). The latitudinal variations seen within the present study area (Figure 25) clearly support this concept. Concentrations of less than $10 \%$ are evident over the Walvis Ridge and the southern Angola Basin and increase to a maximum of $60 \%$ on the Congo Cone.

\section{Ilite}

The concentrations of illite in offshore areas of west Africa reflect the soil composition on adjacent land areas. Illitic soils are dominant in the arid regions of southern Angola and South West Africa and give way to kaolinitic soil groups nearer the equator (van der Merwe, 1966). Therefore, the pattern of illite concentration is nearly the inverse of that of kaolinite (Figure 26). Values between 40 and $60 \%$ characterize the Walvis Ridge region and the nearshore areas off Angola. North of $10^{\circ} \mathrm{s}$, however, concentrations are generally less than $20 \%$.

\section{Methods of Transport to the Deep Sea}

The major mechanisms for the delivery of clay minerals to the marine environment, fluvial and eolian, change in relative importance throughout the study area. The Congo, as the single most important source of fine sediment for the Angola Basin, is the major supplier of kaolinite with lesser amounts probably originating in the Niger River system (Porrenga, 1965) and other smal1 
Figure 25. Distribution of kaolinite in surface sediments of the eastern Angola Basin. 


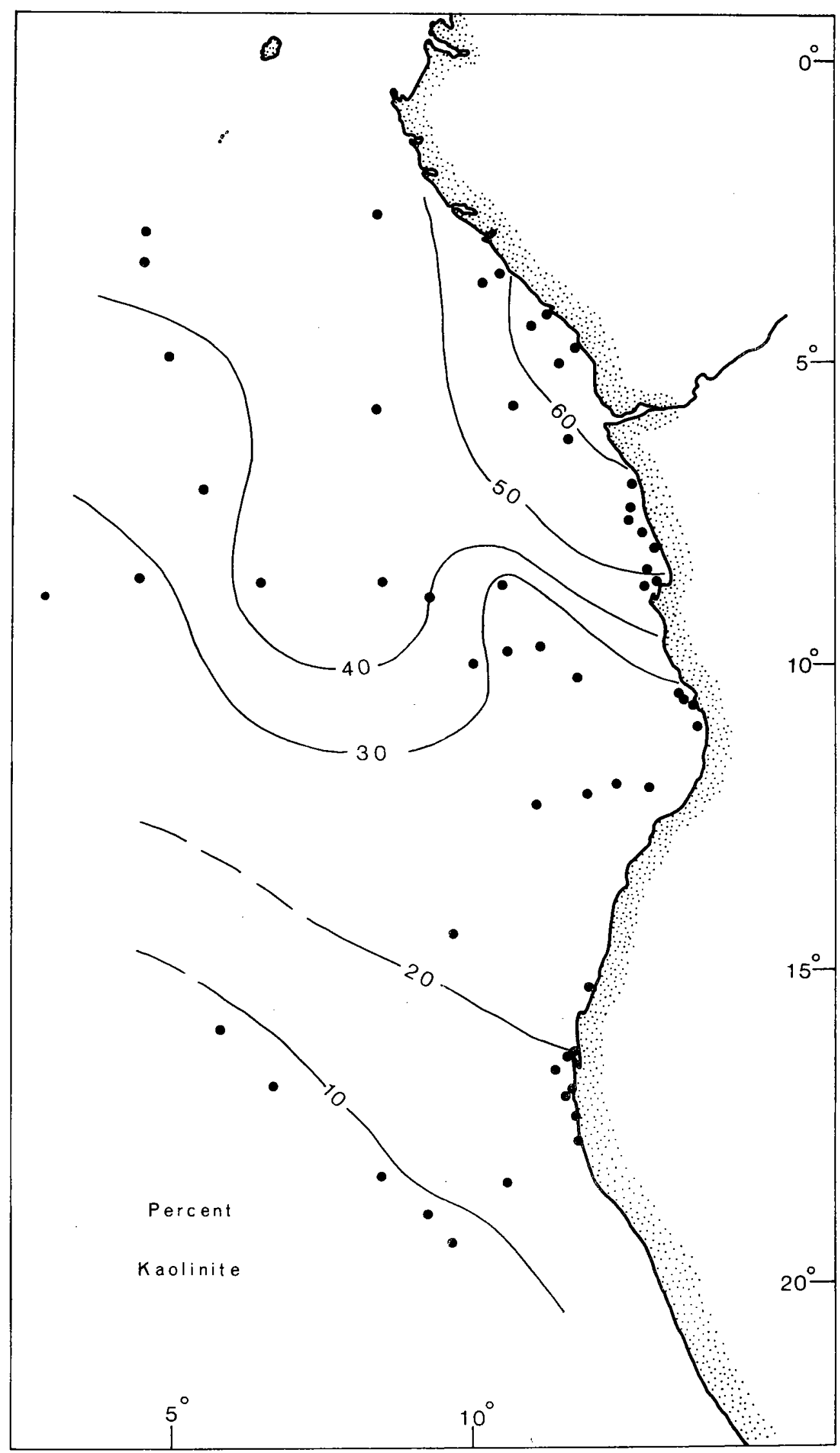

Figure 25 

Figure 26. Distribution of illite in surface sediments of the eastern Angola Basin. 
. 


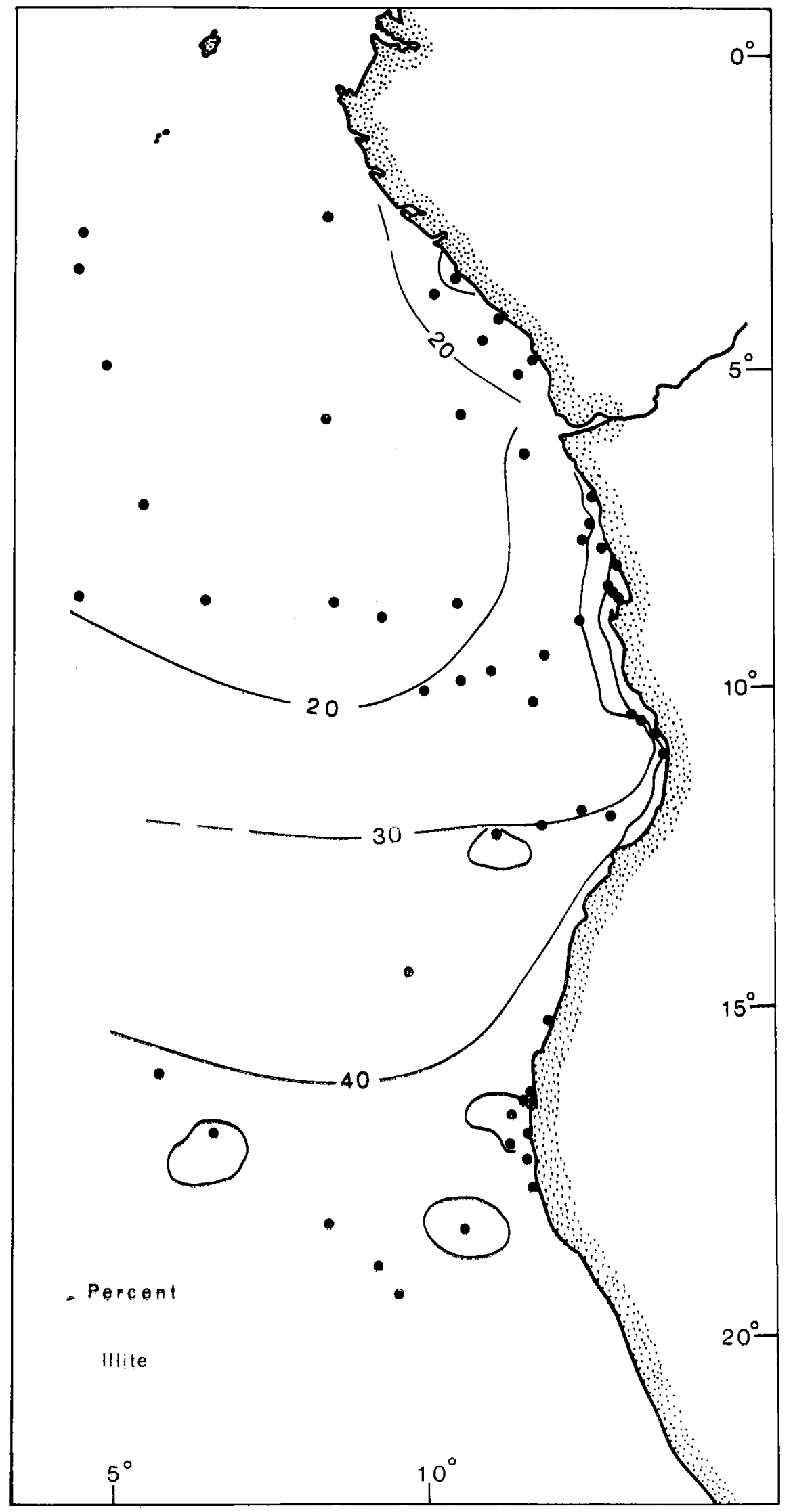

Figure 26 
rivers of Cameroons (Berthois et al., 1968), Gabon and the Congo Republic (Brazzaville). Eolian input of kaolinite to the Angola Basin is not significant at the present time.

Illite and montmorillonite, on the other hand, are dominant clay minerals in the soils of South West Africa and South Africa. In view of the paucity of large rivers in this area, eolian transport probably is more important than farther north (Chester et al., 1972). The prevailing southeast trade winds carry dust northward from the Namib Desert into the Angola Basin and the strong, easterly Berg winds, although only occurring $10 \%$ of the time in South West Africa, account for large volumes of sediment being blown offshore. Illite and montmorillonite also are brought to the study area by the Orange and Kunene Rivers; suspended terrigenous material from both eolian and fluvial sources becomes entrained in the Benguela Current and is carried northward into the Angola Basin area. 


\section{LATE QUATERNARY SEDTMENTS}

Piston cores from the Angola Basin were routinely sampled by the writer at $20 \mathrm{~cm}$ intervals and analyzed for percent sand, percent calcium carbonate within the silt and clay fraction, abundance of the planktonic foraminifera species, the abundance of fecal pellets, and the ratio of planktonic foraminifera to radiolaria. The results of the routine analyses are included in Appendix II and the methods used for the textural and carbonate analyses are presented in Appendix III. The sand fractions of the samples were studied under the binocular microscope and the abundances of the major components were noted.

In addition, clay mineral and organic carbon analyses were conducted on samples selected from the major stratigraphic units (defined on the basis of micropaleontology) within several of the cores. These data are also presented in Appendix II.

\section{Stratigraphy of Deep-Sea Cores}

Several criteria were used in an effort to establish the absolute and relative stratigraphy of the piston cores in the Angola Basin. These included the carbonate content of the 1 ess-than- $62 \mu$ fraction, the abundance of certain species of planktonic foraminifera (Globorotalia menardii, G. menardii var. flexuosa, G. tumida); the ratio of foraminifera to radiolaria, and color differences between major units.

A11 of the cores used in this study were late Pleistocene in age except two (CH99-42 and KW 18), both of which were from the Angola diapir field region and were Pliocene in age. The late Pleistocene cores were in general 
younger than $200-300 \times 10^{3}$ years B.P., and several did not penetrate through the Riss/Wtrm (125,000 yr B.P.) interglacial.

The ideal pelagic section for the late Quaternary in the Angola Basin consists of the following units:

(1) a light-colored, 30-60 cm upper unit, highly calcareous, weakly siliceous, with a typical tropica1-transitional foraminiferal fauna;

(2) a very dark green-gray, 1-2 meter unit, low in carbonate, more highly siliceous (particularly radiolaria), with abundant organic mater, pyritized burrows and fecal pellets; foraminifera are rare;

(3) a unit of alternating light and dark layers similar to units (1) and (2); the overall carbonate content is higher than (2) with warmwater foraminifera occurring in the 1ight-colored, calcareous zones;

(4) a dark green-gray, low carbonate, highly siliceous unit with few foraminifera similar to unit (2).

Despite local variations, this general pattern appears to hold throughout the study area.

A very similar sequence of lithologies was described for cores from the Guinea Basin (Lavrov and Savel'yeva, 1971). Diatoms, however, were found to be a more important constituent of their cores and radiolaria were apparently of very minor importance.

Abundance of the Globorotalia menardii Complex

Ericson and Wollin (1956) proposed that the abundance of the Globorotalia menardii complex was a reliable index of climatic oscillations in the tropical and sub-tropical Atlantic. Since then many other "warm" and "cold" sensitive species have been used to establish climatic curves (e.g., Ruddiman, 1971; Lidz, 1966; Imbrie and Kipp, 1971). As Kennett and Huddlestun (1972) 
point out, however, there is never complete agreement among workers as to which species are "cool" and which are "warm"; they conclude, as did Ericson and Wollin (1956), that the G. menardii complex is one of the most sensitive warm-water indicators. The last appearance of the form $\underline{G}$. menardii var. flexuosa is taken to mark the upper part of the $\mathrm{X}$-zone or the Riss/Wthm interglacial, and provides a key datum in those cores containing G. menardii. Although several cores from the Angola Basin did not contain representatives of the $G$. menardii complex, many other cores could be confidently correlated on this basis (Figure 27). The upper $50-100 \mathrm{~cm}$ in most of these cores is characterized by a warm-water foraminffera fauna, including abundant G. menardii. This zone, the $\mathrm{Z}$, is taken to be the Holocene, the lower boundary of which is marked by a severe reduction with depth in the importance of G. menardii. The underlying unit is characterized by a general absence of G. menardii except for a brief recurrence in the middle of the $\mathrm{Y}$ zone; this brief recurrence is thought to mark the WUrm I/WUrm II interstadial, the peak of which occurred at about $60 \times 10^{3} \mathrm{yr}$ B.P. A major reappearance of abundant G. menardii, G. tumida, and G. menardii var. flexuosa occurs at between 2 and 3 meters in most cores and marks the top of the $\mathrm{X}$ zone. This zone is marked by several peaks of $G$. menardii abundance and extends approximately 2 meters in most cores. A severe reduction again occurs at the $\mathrm{W} / \mathrm{X}$ boundary. The $\mathrm{W}$ zone is characterized by a general absence of $\mathrm{G}$. menardii in its upper part with a gradual increase in its lower sections; correlations become more difficult within the $W$ and earlier zones.

Core V19-280 possesses two peaks of G. menardii abundance within the upper 2 meters, underlain by a long ( 2 meters) section in which this faunal complex is absent. G. menardii var. flexuosa exists in abundance near the 


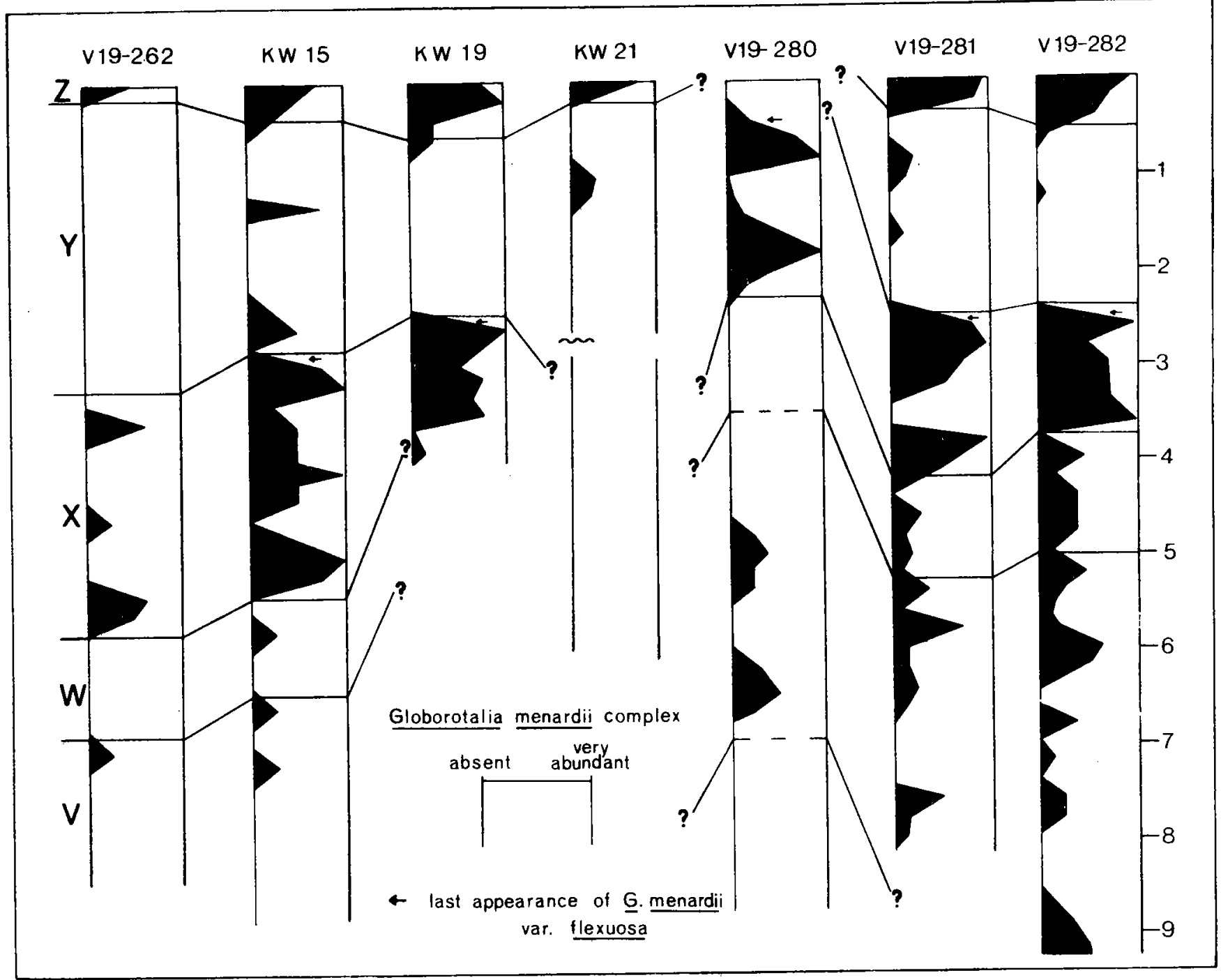

Figure 27. Abundance of individuals of the Globorotalia menardii complex in cores from the eastern Angola Basin. The $\mathrm{X}-\mathrm{Y}-\mathrm{Z}$ zones are based on the relative abundance of this group of foraminifera (Ericson and Wollin, 1956). 
top of the core. On the basis of the above evidence, it was concluded that the upper part of this core lies at about the top of the $\mathrm{X}$ zone $(75,000$ years B.P.).

\section{Paleoclimatic Curves and Stratigraphic Zonation}

The late Quaternary paleoclimatic curve of Emiliani (1971) was used for comparison, but was placed within the Broecker and van Donk (1970) time scale. This time scale was adopted for the present study as it appears to be most compatible with results of other rinds of Quaternary stratigraphic investigations (e.g., Mesole11a et al., 1969) and has been widely used elsewhere in the Atlantic.

This climatic curve was subdivided into the $\mathrm{X}-\mathrm{Y}-\mathrm{Z}$ units and subunits of Ericson and Wollin (1956) and modified from the recent detailed work of Kennett and Huddlestun (1972) in the western Gulf of Mexico. The X-zone represents the interglacial or generally warm interval extending from $75 \mathrm{x}$ $10^{3}$ yr B.P. to $127 \times 10^{3}$ B.P. (Broecker, 1971; McIntyre and Ruddiman, 1972). Kennett and Huddlestun (1972) indicate that the X-zone in the Gulf of Mexico extends from about $95 \times 10^{3}$ B.P. to $127 \times 10^{3}$ yr B.P. (Figure 28). Their work has been modified in the present study (Figure 28) to make the X-zone better correspond with other work in the Atlantic, thus eliminating the subdivisions $\mathrm{Y}_{7}$ and $\mathrm{Y}_{8}$ and adding $\mathrm{X}_{6}$ and $\mathrm{X}_{7}$. As they point out, the western Gulf of Mexico is unique in that Globorotalia menardii disappeared approximately 20,000 years earlier than in the Caribbean or the rest of the tropical At 1 ant ic. 


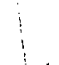


Figure 28. Paleoclimatic curves from Kennett and Huddlestun.'s (1972) work in the western Gulf of Mexico and Emiliani's (1971) work in the Caribbean and Atlantic. The zonation on the right of the figure was adapted from that of Kennett and Huddlestun (1972) for use in the Angola Basin. 



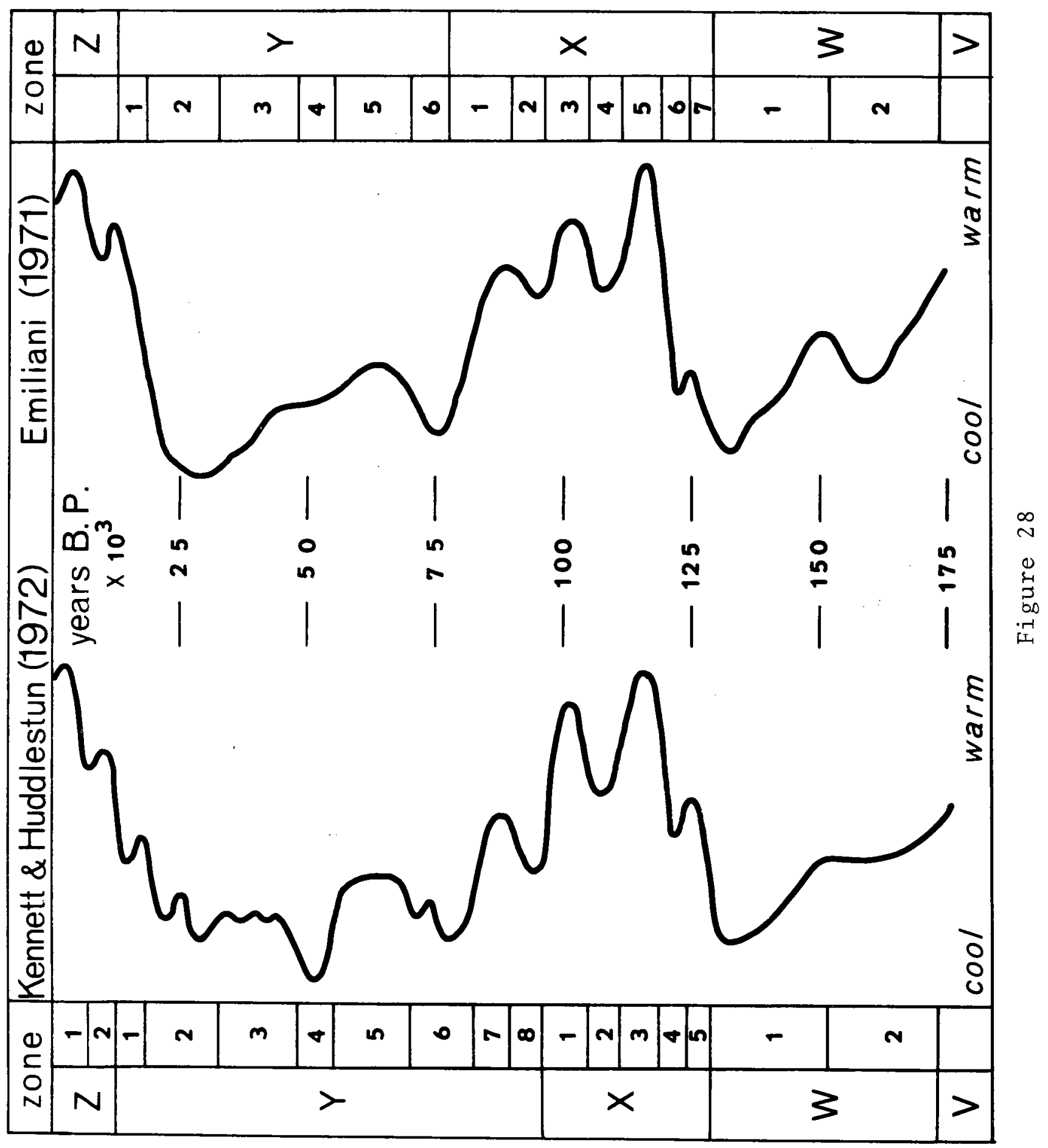


Planktonic Foraminifera/Radiolaria

The relative abundance of planktonic foraminifera has been used by many investigators as a method of subdividing the Quaternary. Emiliani (1955, 1964) used percent sand (as an indication of foram abundance) to demonstrate climatic variations within cores from the Caribbean and found a good agreement with oxygen isotope data obtained on the same samples. Payne and Conolly (1972) found a good direct correlation between foraminifera abundance and inferred Quaternary paleotemperatures in cores taken between Australia and Antarctica. Duncan et al. (1970) used the ratio of planktonic foraminifera to radiolaria in piston cores off Oregon to demonstrate late Quaternary climatic changes. They found that the Holocene was characterized by a relatively high abundance of radiolaria, whereas the glacial intervals exhibited higher concentrations of planktonic foraminifera.

Foraminifera/radiolaria curves in many Angola Basin cores also show good correlations with inferred climatic curves based on other criteria (Figure 29). As with carbonate curves, however, the correlation is the inverse of that found in northeast Paciflc cores: interglacials are characterized by higher planktonic foraminifera abundances than glacials.

\section{Variations in Calcium Carbonate Abundance}

Variations in calcium carbonate content have been shown to be correlated with climatic change (e.g., Schott, 1935; Arrhenius, 1952; Ruddiman, 1971; Hays and Perruzza, 1972). In general, glacial periods have been characterized in Atlantic deep-sea sediments by low carbonate values and interglacials by high values. This pattern contrasts with the Pacific Ocean, where precisely the opposite correlation exists. The factors controlling these climatically 
Figure 29. Vertical changes in the foraminifera/radiolaria ratio in cores from the eastern Angola Basin. 



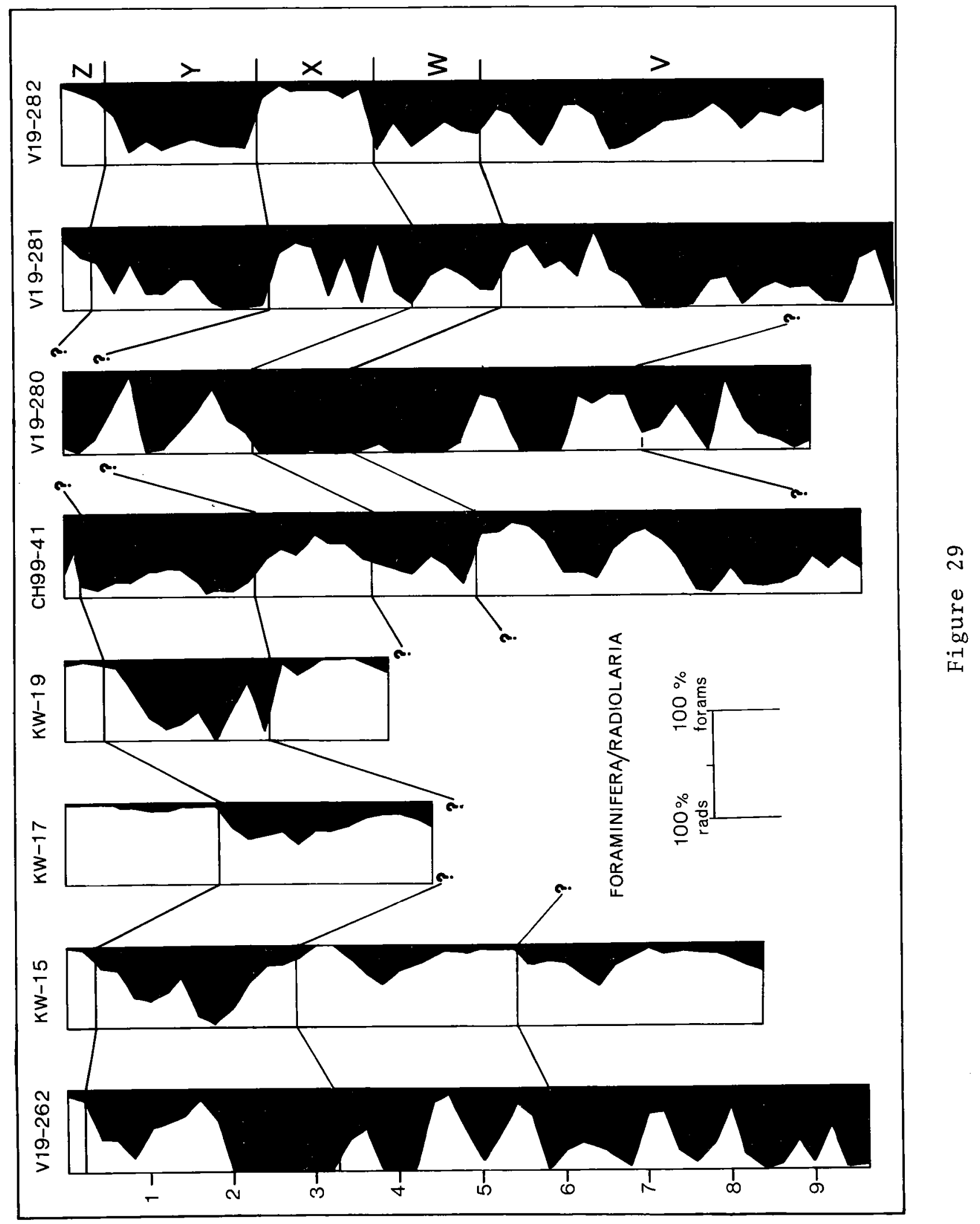


related variations include:

(1) changes in carbonate productivity in surface waters;

(2) varying rates of terrigenous dilution; and

(3) changes in the rate of carbonate dissolution.

Figure 30 shows profiles of carbonate abundance in several of the Angola Basin cores in which pelagic sedimentation was dominant. The time scale was based on: (1) the projection of deduced sedimentation rates; (2) comparison with other Atlantic cores; and (3) Globorotalia menardii abundance. Core V19262 provides an ideal example of the variations in calcium carbonate seen in cores from the eastern Angola Basin. The major units, defined on the basis of carbonate content can be correlated with the X-Y-Z zones based on foraminifera; for this reason, these units will be given $X-Y-Z$ designations even though $G$. menardil may not exist within the core.

Most cores are characterized by a rapid decrease in carbonate content with depth in the upper $50-60 \mathrm{~cm}$. This zone corresponds to the Holocene, the $\mathrm{Z}$ zone of Ericson and Wollin (1956), and begins approximately 12,000 years B.P. Cores from regions of presently higis carbonate productivity (Walvis Ridge and the Guinea Rise) show variations in carbonate content from as high as $85 \%$ at the surface to less than $10 \%$ at the base of the Holocene. In some cores (e.g., V19-261, KW15, KW19) maximum carbonate values are not at the surface but are $20-40 \mathrm{~cm}$ down in the cores: this may represent a slight climatic deterioration since the climate optimum; in other cores this section may have been removed during the coring operation.

Below this surface unit is a one to two-meter unit of low carbonate content, broken only by a sma11 subunit of slightly higher carbonate $\left(Y_{3}\right)$. This unit is taken to be correlative with the $Y$ zone of Ericson and Wollin (1956) and comprises the WHrm I and II glacial intervals and the intervening inter- 
Figure 30. Vertical changes in the calcium carbonate content of the less-than-62 $\mu$ fraction in cores from the Angola Basin. 


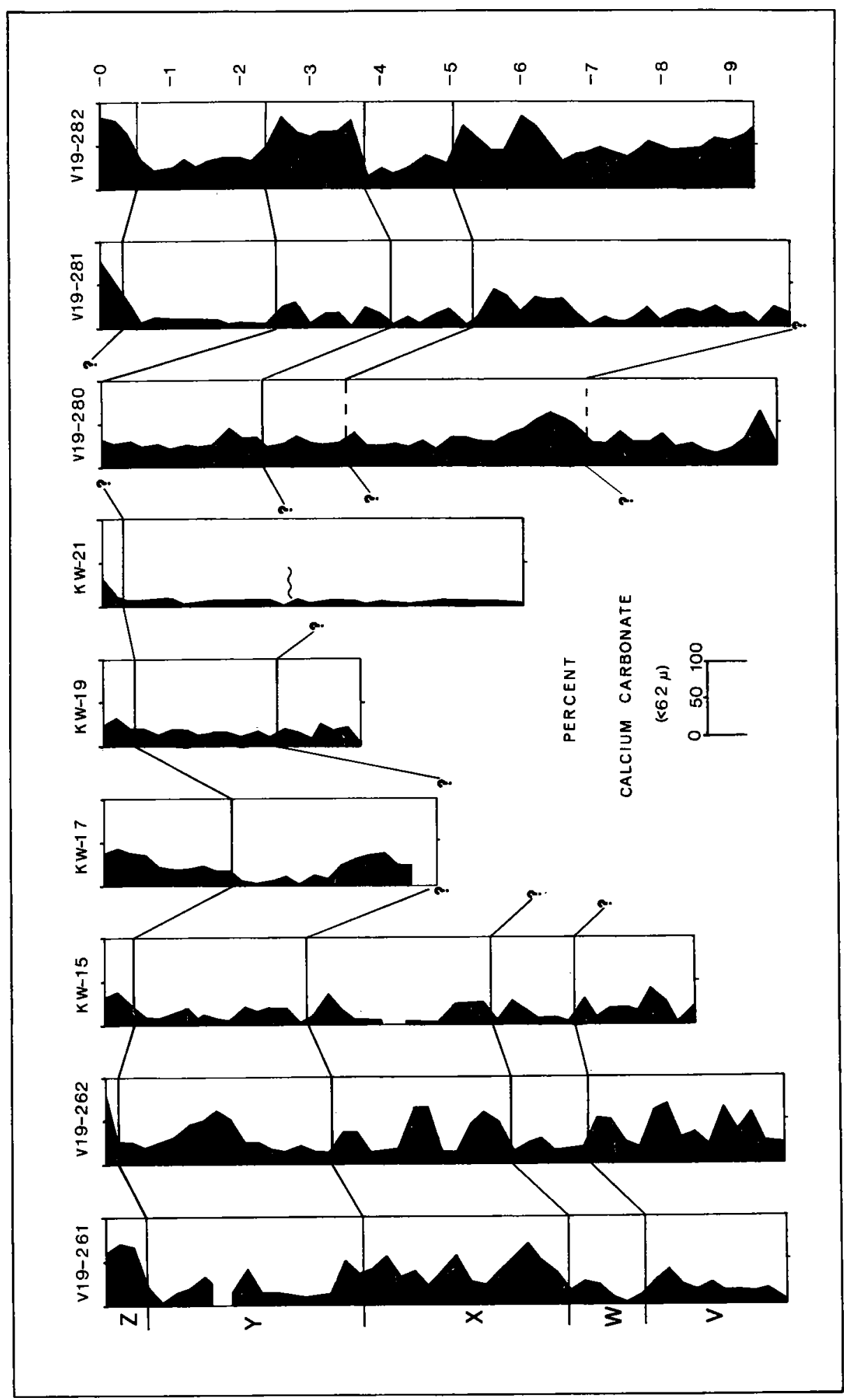

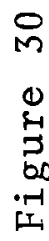


stadial (WUrm I/WUrm II), as evidenced by the s1ight ly higher carbonate values. Often the lowest carbonate values encountered in these cores are from this unit.

Below this zone is a generally more calcareous unit containing three major carbonate maxima and exhibiting a wide range of carbonate values. Differences between maxima and minima within this unit can be as great as $50 \%$ as in core V19-262, but are usually in the order of 20 to $30 \%$. This unit is correlative with the X zone of Ericson and Wollin (1956), the Riss/WUrm interglacial.

Correlations become more difficult in units underlying the X-zone. There appear, however, to be two minima in carbonate separated by a slight maximum. This unit is thought to correspond to the W zone of Ericson and Wollin (1956).

This basic scheme is only evident in areas dominated by pelagic sedimentation and is totally non-existent in cores from the Congo Cone. Elsewhere slumping and turbidity current erosion and deposition obscure the genera1 pattern described here.

Core CH99-38, though of exclusively pelagic character, contains virtual1y no carbonate along. Its entire lengtn. Taken at $5371 \mathrm{~m}$ the sediments at this location probably have always been below the carbonate compensation depth. Other cores (e.g., V19-281, V19-261, V19-262) contain pelagic sections in which no carbonate is present; in other cores carbonate components show evidence of dissolution in certain sections. These units can be as much as one to two meters in length and correspond to increases in pellets, siliceous components, organic content, and pyritized burrows. Although one might expect a general reduction in total $\mathrm{CaCO}_{3}$ with climatic deterioration, carbonate productivity in the surface water should not cease entirely. For this reason these non-calcareous units may reflect changes in the position of the car- 
bonate compensation depth; the mechanism by which this might have been achieved will be discussed in a later section.

As mentioned previously, carbonate content can be affected in three ways: (1) by changes in carbonate productivity; (2) by terrigenous dilution; and (3) by carbonate dissolution. Ruddiman (1971), Broecker (1971), and Hays and Perruzza (1972) concluded that the lower carbonate values during glacial intervals reflect the increased deposition of terrigenous sediment in the ocean, not a decrease in carbonate productivity. Several problems are associated with this interpretation. If carbonate productivity is assumed to remain constant, as stated by Hays and Perruzza (1972), then a threefold change in percent carbonate (e.g., from $30 \%$ to $10 \%$ ) between interglacials and glacials must be accompanied by higher terrigenous inputs and consequently higher sedimentation rates. In core V22-196, Hays and Perruzza (1972; p. 358) show that average interglacial carbonate values are approximately $30 \%$ and glacial values $10 \%$. However, interglacial sedimentation rates are $5.4 \mathrm{~cm} / 10^{3}$ years and glacial sedimentation rates are $5.0 \mathrm{~cm} / 10^{3}$ years. Clearly a sedimentation rate which remains relatively constant from interglacial to glacial intervals cannot account for a threefold decrease in the observed carbonate content if carbonate production is held constant. Other mechanisms, presumably changes in carbonate productivity or dissolution, must be important factors in reducing carbonate content.

This conclusion is further substantiated by results from the Angola Basin: although carbonate values during glacials can be as much as four to five times lower than during interglacials, glacial sedimentation rates are comparable to interglacial rates. Increased terrigenous dilution during glacials is not consistent with work carried out on land in areas adjacent 
to the Angola Basin. As mentioned previously, the region of the Congo as far inland as Kinshasa was a desert or semi-desert during glacial intervals. Recent work by Degens and others (personal communication, 1973) on equatorial lakes and by van Zinderen Bakker and Coetzee (1972) supports the view that cooler periods in higher latitudes were equivalent to drier periods in equatorial Africa.

\section{Sedimentation Rates}

On the basis of the above criteria, sedimentation rates for glacial and interglacial intervals were determined for the best controlled cores in the study area (Table 1). An average glacial sedimentation rate was determined for the entire $\mathrm{Y}$ zone, although it was realized that this comprises the WUrm I and WUrm II glacial maxima separated by an interstadial (WUrm I/ WUrm II). An average interglacial sedimentation rate was calculated for the Riss/ Wtrm interglacial $\left(127-75 \times 10^{3}\right.$ years B.P.).

Pelagic sedimentation rates for both glacial and interglacial intervals average approximately $3-5 \mathrm{~cm} / 10^{3}$ years, with very little difference, in general, between warm and cool periods. This is in marked contrast to the Guiana Basin off the Amazon River, described by Damuth and Fairbridge (1970), where they inferred greatly increased sedimentation rates during cool intervals. The land areas adjacent to both the Guiana and Angola Basins experienced arid to semi-arid conditions during glacial periods. Damuth and Fairbridge (1970) believed that an increase in sedimentation rates during glacials occurred in response to a deforestation of areas which are presently tropical rain-forest, and to the growth of mountain glaciers in the Andes, the source of the Amazon. Two important features, however, distinguish the 
TABLE 1.

SEDIMENTATION RATES IN THE EASTERN ANGOLA BASIN

$\begin{array}{lcc}\text { Core } & \text { Glacial }\left(\mathrm{cm} / 10^{3} \mathrm{yr}\right) & \text { Interglacia1 }\left(\mathrm{cm} / 10^{3} \mathrm{yr}\right) \\ \text { V19-261 } & 6.0 & 5.7 \\ \text { V19-262 } & 4.4 & 5.0 \\ \text { KW-15 } & 4.0 & 4.4 \\ \text { KW-19 } & 3.3 & 3.1 \\ \text { CH99-41 } & 3.2 & 2.9 \\ \text { V19-280 } & - & 4.1 \\ \text { V19-281 } & 3.2 & 3.3 \\ \text { V19-282 } & 3.0 & 2.7\end{array}$


Congo River system from that of the Amazon: (1) the sources of Congo River water are not in areas which were extensively glaciated during glacial maxima; and, (2) most of the sediment carried by the Congo into the Atlantic Ocean is derived from the area within $400 \mathrm{~km}$ of the coast. Thus, although during cool periods of physical weathering in the deforested areas near the coast may have been intensified, the discharge of the Congo and its lower tributaries undoubtedly decreased significantly (dePloey, 1965; Fairbridge, 1964) resulting in relatively constant sedimentation rates throughout the 1 ate Quaternary in the eastern Angola Basin.

Sand and Silt

Emiliani (1955, 1964), Ericson and Wollin (1956), Ewing et al. (1958), and Ericson et al. (1961) showed that the weight percentage of sediment larger than $62 \mu$ (or $74 \mu$ ) often displayed a high correlation with inferred paleotemperatures in Globigerina-ooze cores from the Atlantic Ocean. Severa1 cores from the eastern Angola Basin exhibit agreement between the percentage sand and carbonate values for the less-than- $62 \mu$ fraction, the abundance of the Globorotalia menardi1 complex, and the foraminifera/radiolarian ratio. The best correlations are apparent in cores from the Walvis Ridge and fram the Guinea Rise, where normal pelagic sedimentation is less influenced by coarse terrigenous sediment input than the Angola continental rise and abyssal plain (Figure 31). Correlations between carbonate and percent sand are not as great as those found elsewhere in the Atlantic principally because of the relatively large input of siliceous components.

In addition to planktonic foraminifera, radiolaria, and diatoms, the sand fraction disseminated throughout the hemipelagic sections of the Angola Basin cores commonly consists of fine quartz, feldspar, mica, glauconite, 
Figure 31. Relationship between percent sand $(>62 \mu)$, calcium carbonate content of the silt and clay, and the foraminifera/radiolaria ratio in core V19-281 from the southern flank of the Guinea Rise. 



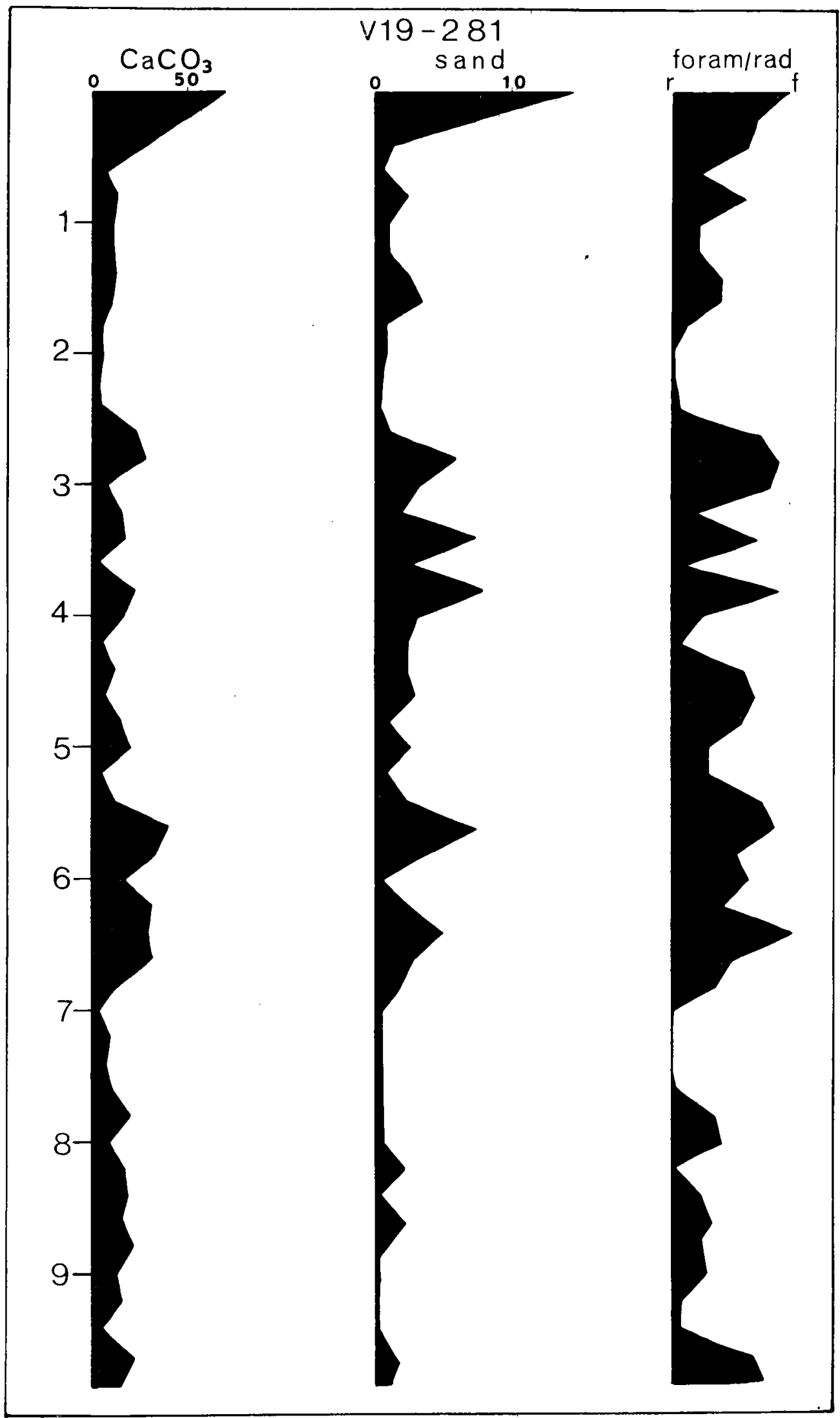

Figure 31 
manganese micronodules, fecal pellets, pyritized foraminifera and diatoms, pyritized burrows, echinoid spines, benthonic foraminifera, ostracods, and bryozoa. Fish teeth and black, perfectly spherical, shiny, non-magnetic particles are occasionally found (Figure 32).

Mica, glauconite, and manganese show definite latitudinal differences in their contribution to the sand fraction. Manganese micronodules are more common in the northern part of the basin than in the southern. Mica is particularly abundant in cores from the Angola continental rise and is absent from the pelagic sections of cores V19-280, 281, and 282 from the southern flank of the Guinea Rise. Not unexpectedly, continental shelf sediments from off South West Africa and Angola contain appreciably more mica than sediments from the shelf off Congo and Gabon. I11ite (mica) in the clay fraction also is considerably more abundant in the southern part of the study area (see previous section).

Glauconite is also noticeably more prevalent along the Angola, Congo, and Gabon continental margins than on the north flank of the Walvis Ridge or on the Guinea Rise. The source and mode of origin of this glauconite is discussed below. No vertical variations in glauconite abundance were apparent in cores from this area.

Pyrite is a very abundant component of Angola Basin cores and displays vertical variations in importance within cores. It occurs in two general forms: (1) as replacements or fillings of planktonic foraminifera and diatom frustules; and (2) as replacements of burrows of benthic organisms. The latter are long, narrow "rods" exhibiting a fine, botrycidal surface texture (Figure 33). Both modes of occurrence can range from well-developed pyrite with a high metallic luster to a poorly developed black iron sulfide precursor 
Figure 32. Photomicrograph of a smooth, spherica1, non-magnetic particle found in Angola Basin core KW19. Scale bar represents $0.5 \mathrm{~mm}$. 



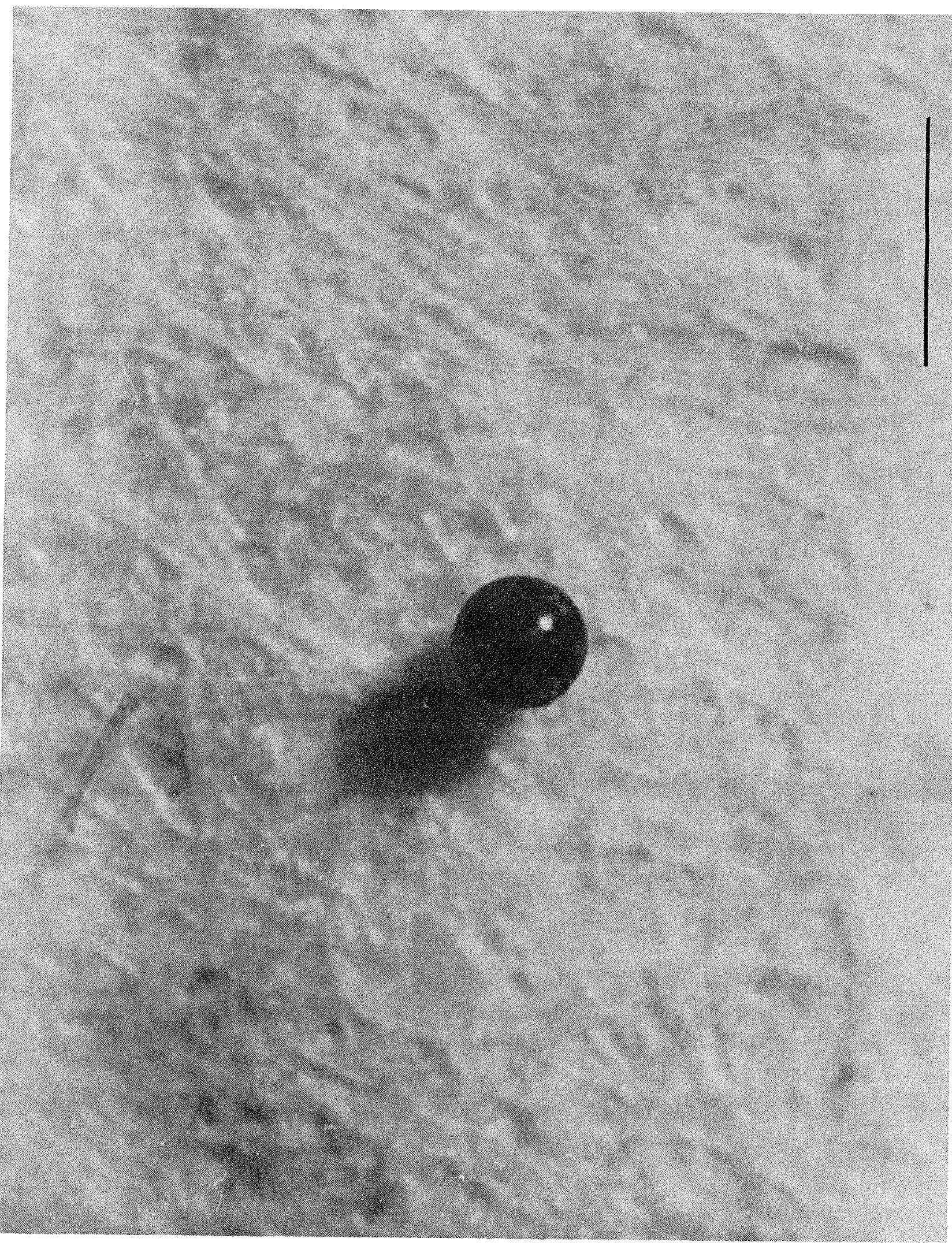

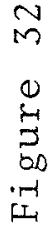


Figure 33. Photomicrograph of pyritized burrows from Angola Basin core V19-278. Scale bar represents $0.5 \mathrm{~mm}$. 
• 


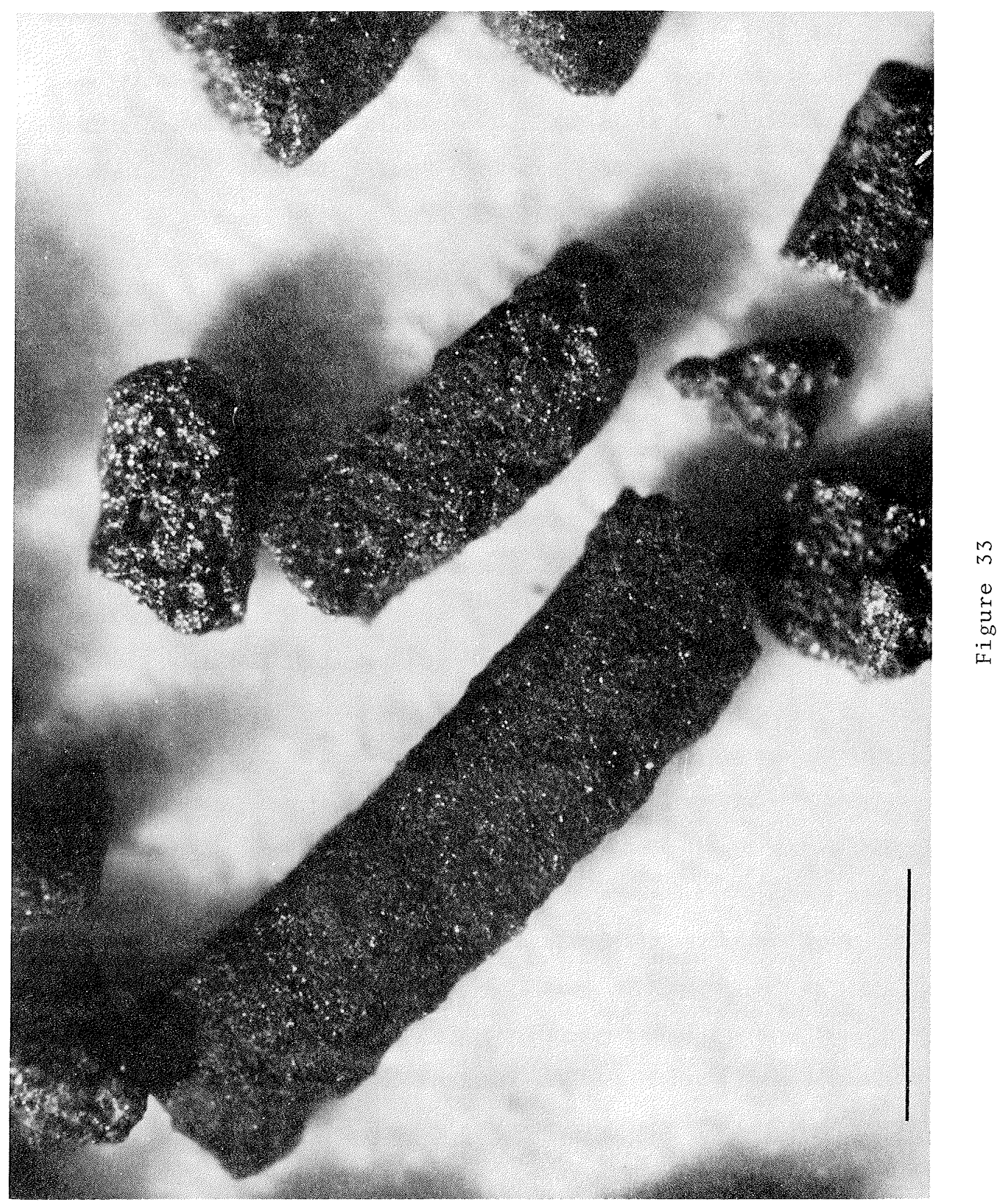


of pyrite (hydrotroilite ?) with a du11 nonmetallic luster; burrows are more commonly of the latter type. In general, pyrite is most abundant in lowcarbonate sections of the cores from this region and often can constitute the entire sand fraction (e.g., CH99-40; V19-278, $120 \mathrm{~cm}$ ). A similar relationship between pyrite and dark gray-black sediment sections in the Guinea Basin was noted by Lavrov and Save1'yeva (1972).

\section{Turbidites}

The contribution to the Angola Basin sediments of silt and sand derived from turbidity currents varies from negligible on the northern flank of the Walvis Ridge and the southern flank of the Guinea Rise (except near volcanic islands and major seamounts) to extremely important on the Angola abyssal plain and the Congo Cone (Figure 34). Cores V19-263, 264, and 265 from the southern abyssal plain are dominated by sub-angular to sub-rounded, fine to medium quartz sands with appreciable mica, benthonic foraminifera, radiolaria, and fecal pellets. Minor constituents include glauconite, pyritized burrows, planktonic foraminifera, byrozoa, ostracods, sponge spicules, and sma11, polished dark grains (phosphorite ?). Very large, frosted and very well rounded, quartz grains were found in core V19-264. The great abundance of quartz and mica and the almost complete absence of mafic minerals indicates that these turbidites originated on the Angola continental shelf and slope and not on the nearby Walvis Ridge.

Sand layers in cores from the Angola rise and from the sediment ponds within the Angola diapir field consist of essentially the same components as the sand disseminated throughout the pelagic sections.

Heezen et al. (1964) discussed in detail the composition, texture, and distribution of silt and sand on the Congo Cone. Two heavy mineral suites 
Figure 34. Average centimeters of sand and silt layers per meter of core in the eastern Angola Basin. 


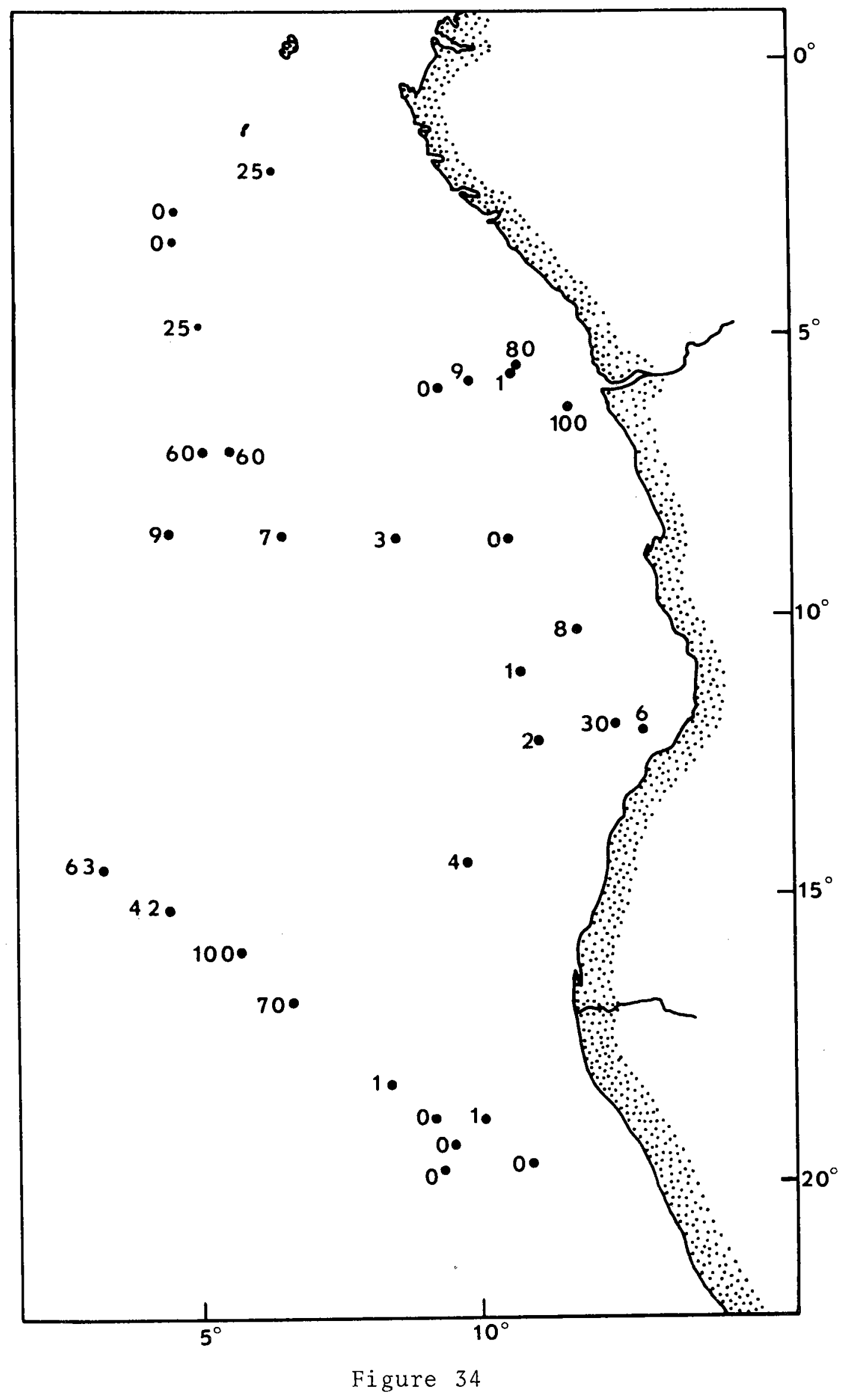


were identified, one containing abundant black opaque minerals, the other containing hematite. The former is thought to have been derived from sediment transported by longshore drift into the canyon head. The latter was found comonly in association with terrestrial plant material and is believed to have come directly from the Congo River. Based on the frequency of submarine cable breaks, Heezen et al. (1964) estimated that the Congo Canyon is presently experiencing approximately fifty major turbidity currents per century.

\section{Fecal Pellets and Authigenic Silicates}

Three types of pellets were found within the study area: (1) a grey, du11, "speckled" ellipsoidal type of dominantly smectite composition; (2) a shiny, brown-grey, ellipsoidal variety of chamosite composition (Emel'ianov and Senin, 1969); and (3) a shiny dark-green-black ellipsoidal to irregular variety of glauconite composition (Giresse, 1965; 1969).

According to Emel'ianov and Senin (1969) chamositic pellets develop within estuaries, such as the Ogooue or Congo, at depths of less than 70 meters and locally can constitute more than $40 \%$ of the sediment. Goethite is an important constituent of these pellets particularly at depths shallower than $40 \mathrm{~m}$. These pellets are very abundant in samples from the Congo and Gabon continental shelf (Figure 35) and are commonily found in areas from the Congo Cone and continental rise, and are abundant within turbidite unites in these areas.

Grey pellets (Figure 36) are ubiquitous components of both pelagic ard turbidite units of Angola Basin cores, particularly from the southern part of the study area. Since they are not restricted to turbidite units, and since they are not found in adjacent continental shelf sediments, these pellets are believed to have been produced in situ in the deep sea. The abundance of 
Figure 35. Photomicrograph of chamosite pellets from the continental shelf off the Congo Republic. Scale bar represents $0.5 \mathrm{~mm}$.

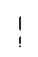





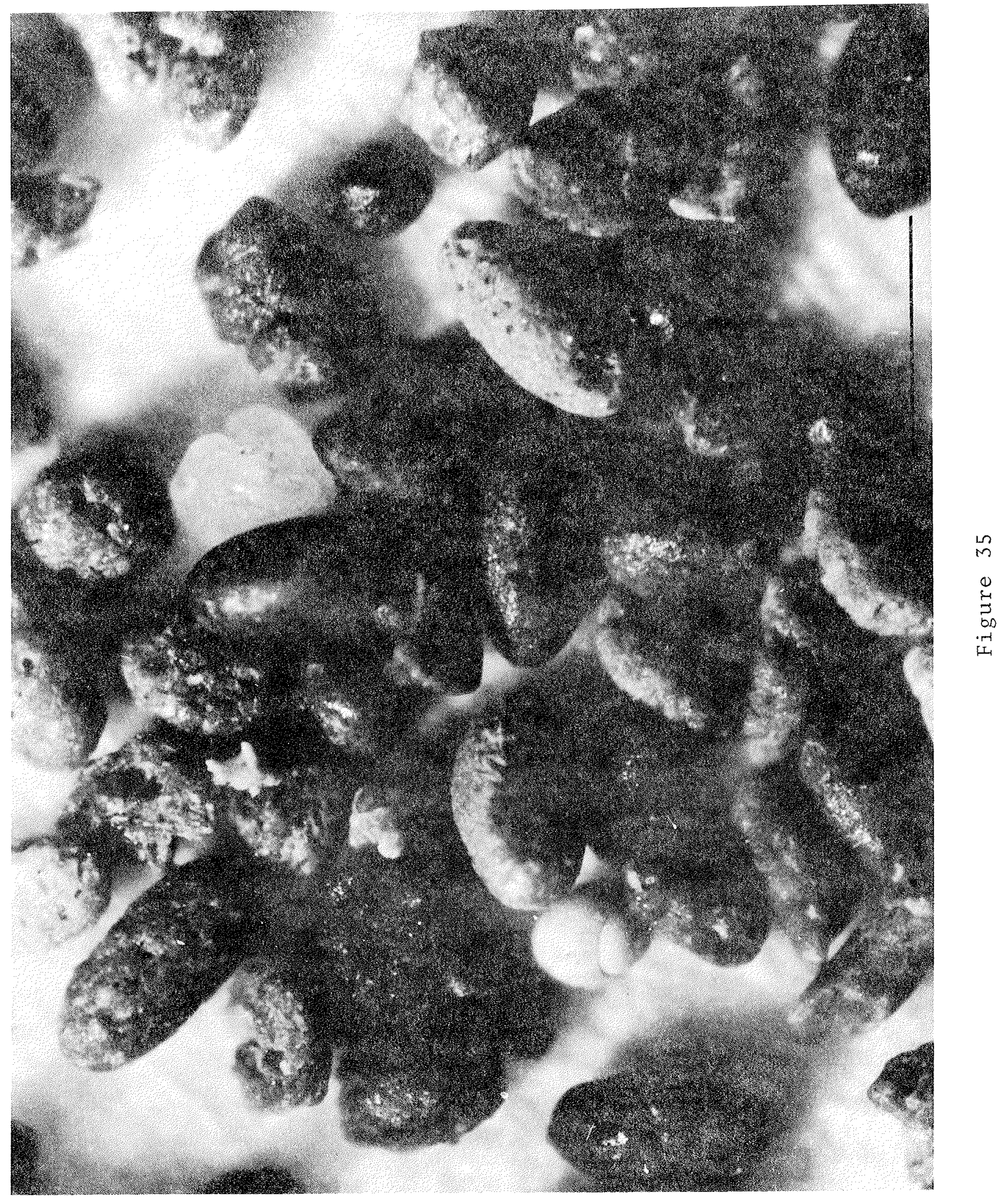


Figure 36. . Photomicrograph of grey pellets from core KW15 on the continental rise off southern Angola. Scale bar represents $0.5 \mathrm{~mm}$. 



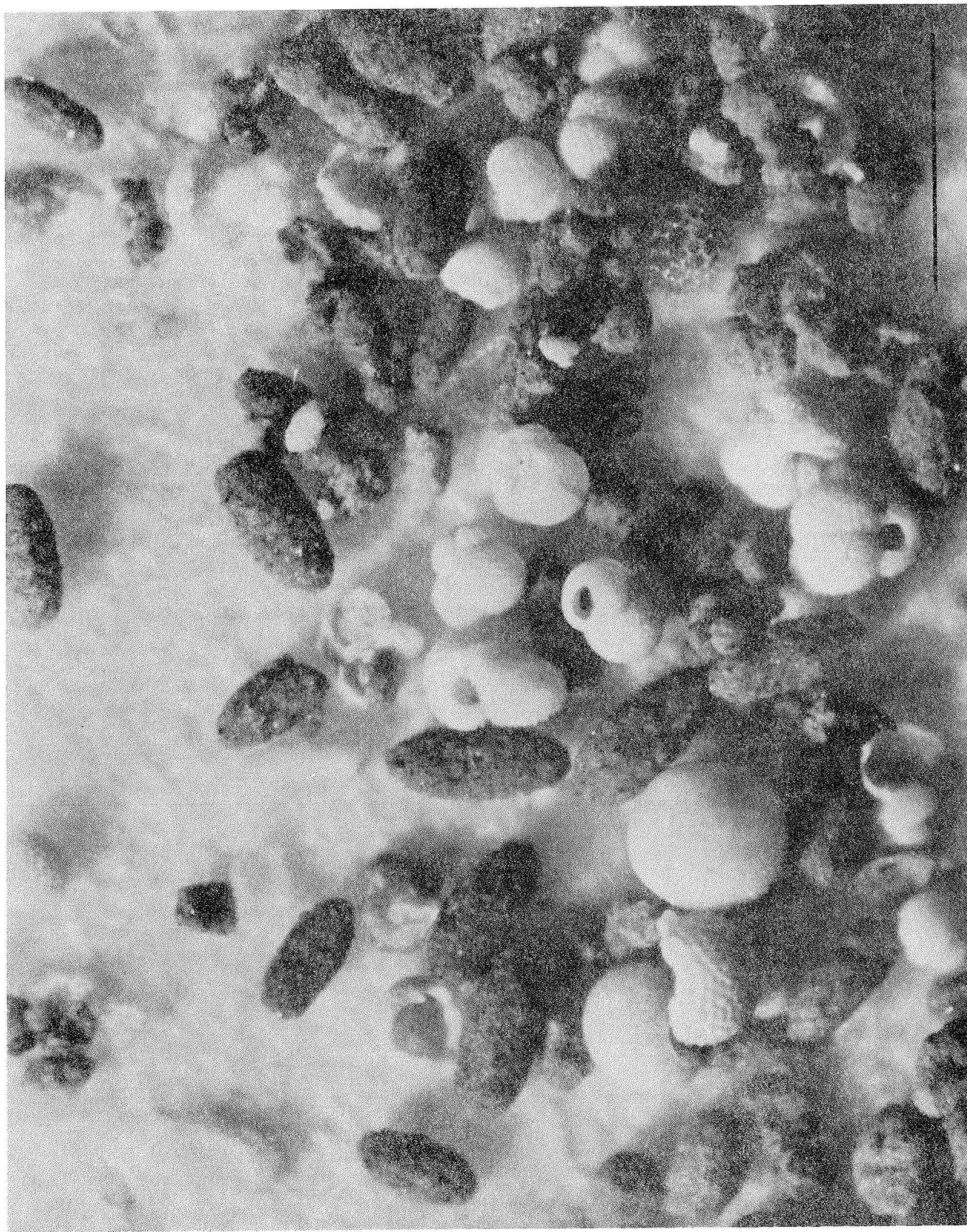

0
$m$
0
5
5
0
01
15 
this variety of pellet shows significant variation with depth in cores and displays a good correlation with the abundance of other components, as exemplified by core KW15 (Figure 37). Pellets, in general, are significantly more common in zones of low carbonate. This is particularly apparent for the suite of cores from the southern part of the study area; cores V19-280, V19281, V19-282 from the Guinea Rise do not contain appreciable amounts of pellets and do not exhibit any clear variations with depth.

Glauconite is a very abundant constituent of both continental shelf and offshore sediments in this area. It generally occurs as either shiny, dark green-black to light green pellets or as replacements of foraminifera tests. The dark green-black variety is particularly abundant on the shelf off Congo and Gabon (Giresse, 1965; Giresse, 1969; Giresse and Kouyoumontzakis, 1971) (Figure 38). Light green glauconite, usually in the form of replaced foraminifera tests, is much more common in cores from the Angola Basin (Figure 39). The abundance of the latter type in the pre-Quaternary core KW-18 suggests that much of the glauconite within the Quaternary cores may have been reworked from older sediments exposed during slumping and sliding associated with the diapiric tectonism of the Angola diapir field. Glauconite is generally absent in cores from the Walvis Ridge and the Guinea Rise.

According to Emel'ianov and Senin (1969) glauconite is presently forming in the estuaries of the Ogooue and Congo Rivers at depths below $50 \mathrm{~m}$ and on the Congo, Gabon and Angola continental shelves. The richest shelf concentrations of glauconite (10-90\% of the total sediment) occur off the Kunene River along the outer shelf. 
Figure 37. Relationship between pellet abundance and the abundance of G. menardii, calcium carbonate in the silt and clay fraction, percent sand, and the foraminifera/radiolaria ratio. 



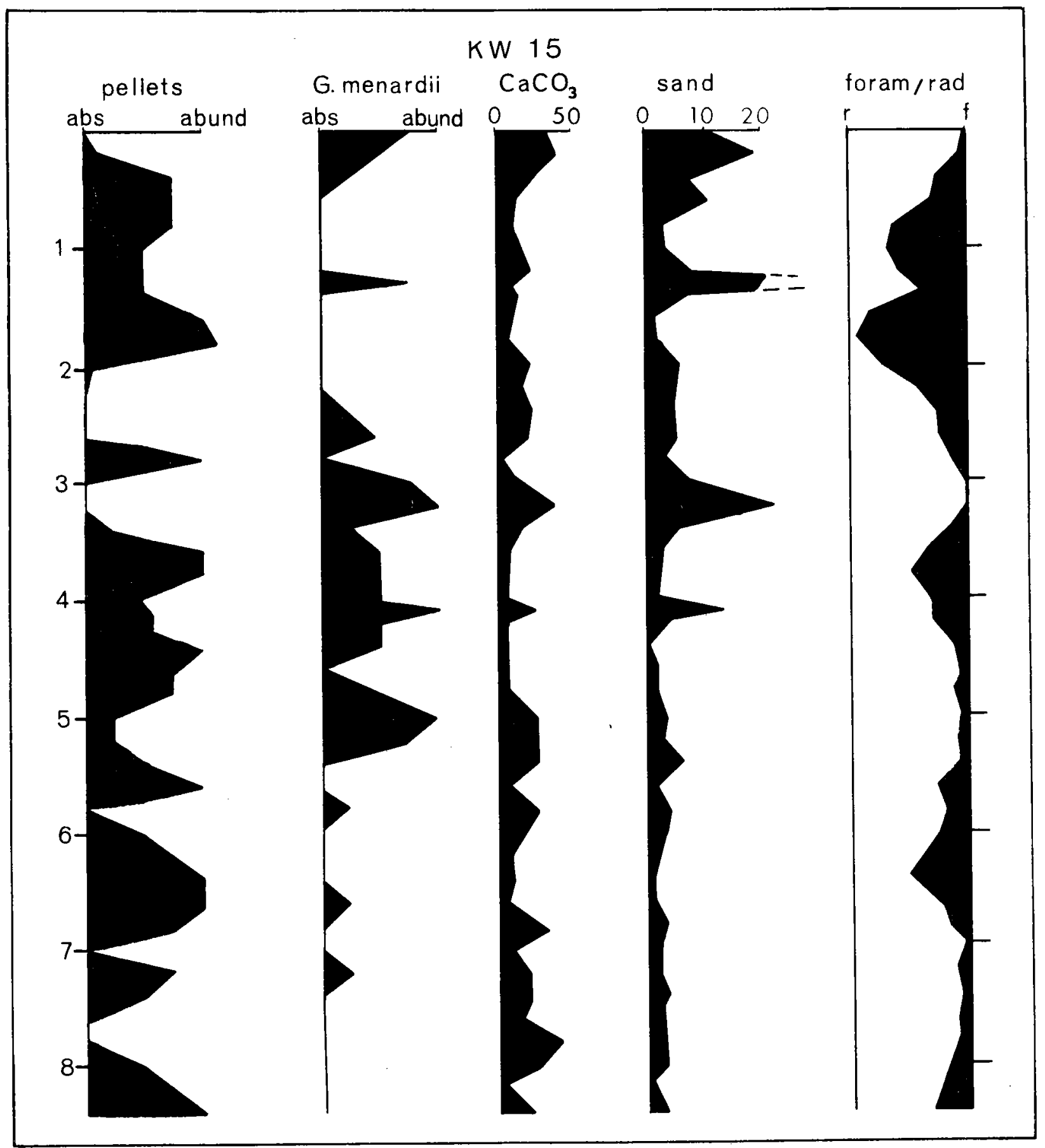

Figure 37 

Figure 38. Photomicrograph of glauconite and chamosite pellets from the continental shelf off Gabon. Scale bar represents $0.5 \mathrm{~mm}$. 



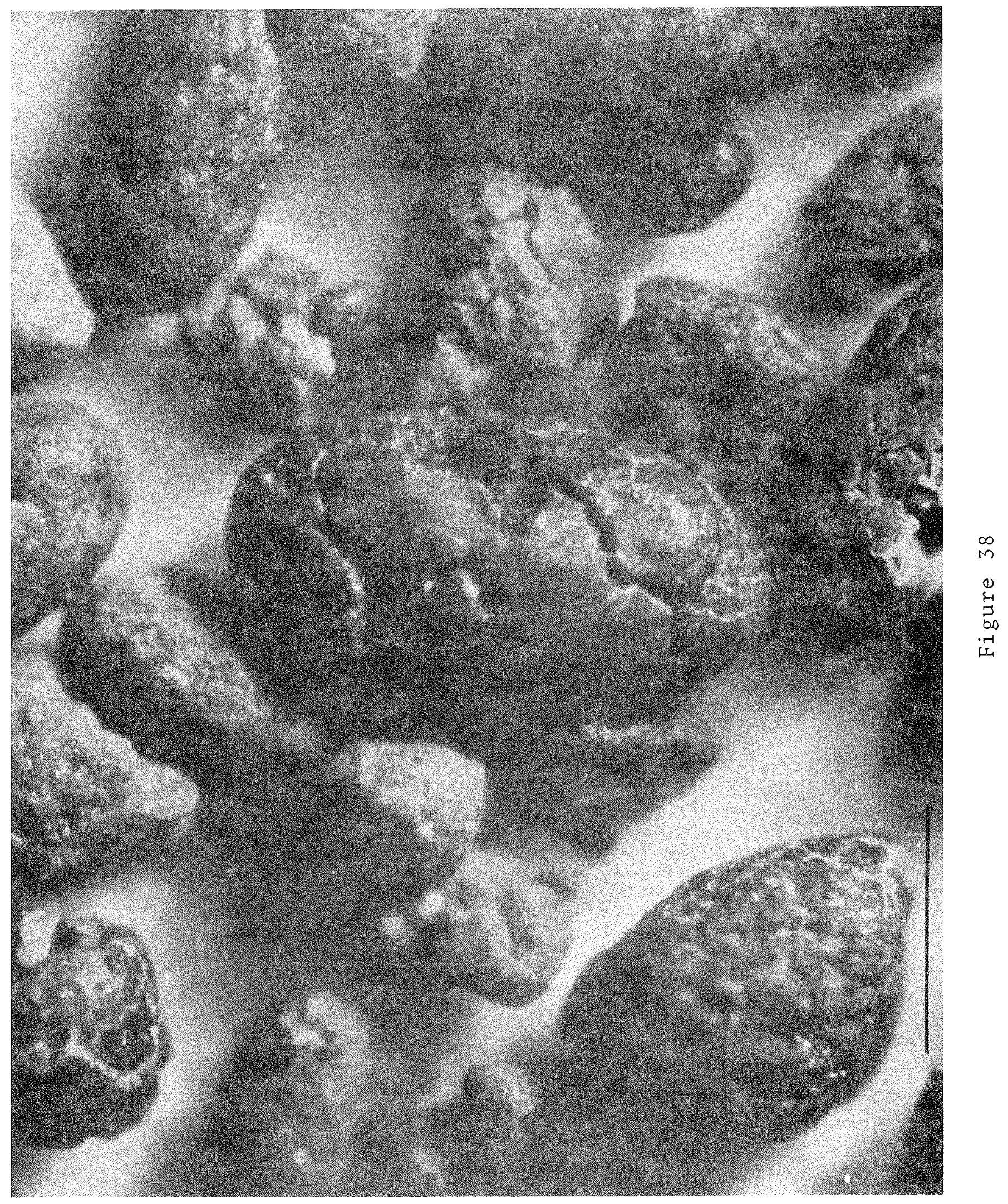



Figure 39. Photomicrograph of glauconite from core KW18 off central Angola. Scale bar represents $0.5 \mathrm{~mm}$. 



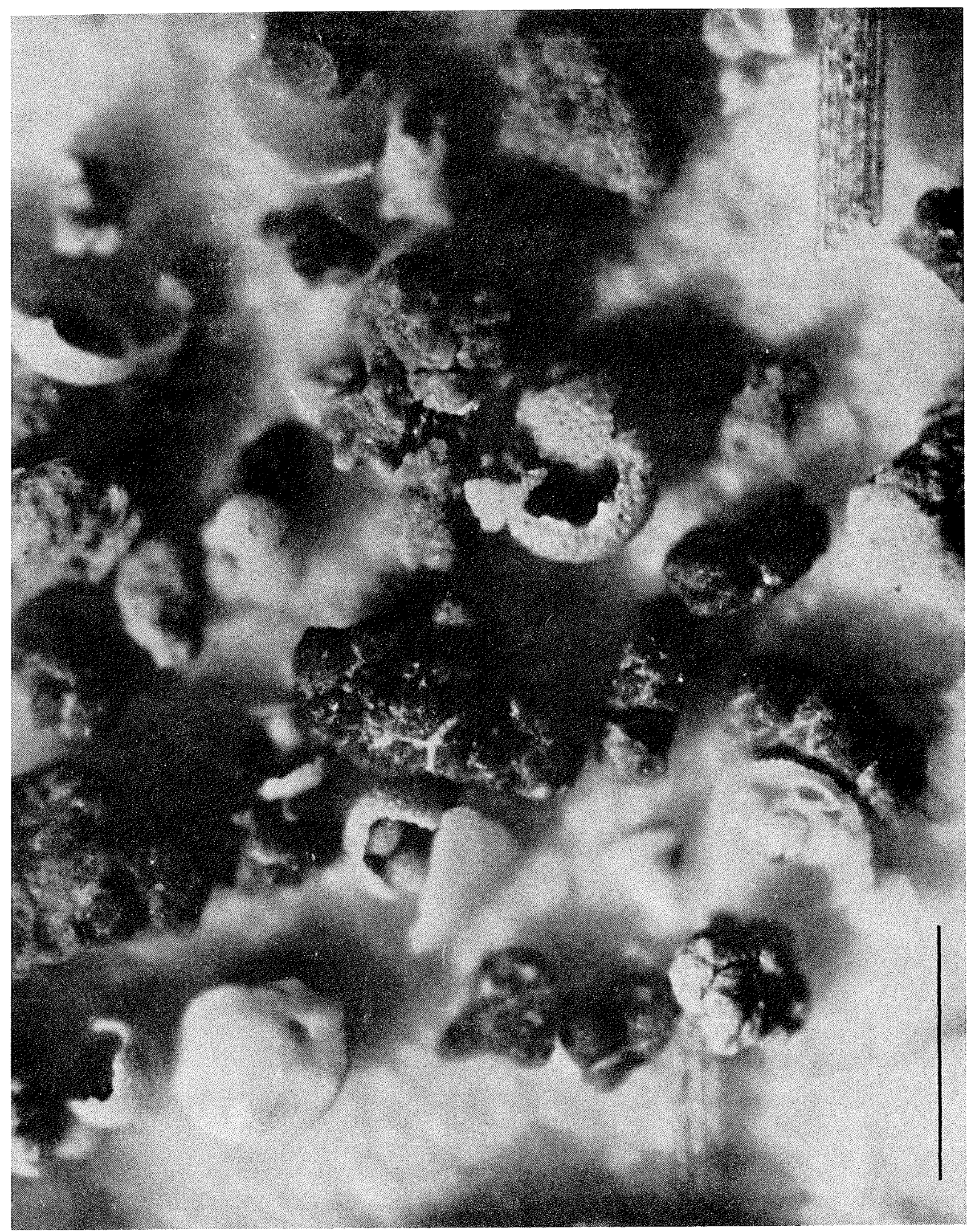

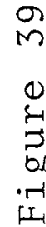




\section{Vertica1 Changes in Clay Mineral Abundance}

In an effort to assess lateral vartations in the clay mineral assemblage through the late Pleistocene and Holocene, samples were analyzed from the major stratigraphic units of five cores from the Walvis Ridge to the Guinea Rise. Ten to fifteen samples in each core were analyzed and the results summarized in Figure 40 for montmorillonite, illite, and kaolinite.

As can be seen, several apparently significant trends exist within individual cores, although no clear relationship to climatic change for the basin as a whole is evident. The same overall trends observed in the surface sediments are apparent in these cores: illite decreases and kaolinite and montmorillonite increase from south to north. The reason for the lack of any clear vertical changes in clay mineral assemblage within the entire basin is not obvious in the light of the available data. However, the more intense circulation of bottom water in the Angola Basin during glacials, inferred from other evidence, may have redistributed clay minerals throughout the basin, thus obscuring vertical variations.

\section{Organic Carbon}

Organic carbon content, determined on selected samples from the major stratigraphic units of several cores in the Angola Basin, changes markedly between cool and warm periods, as shown by the inverse correlation between organic carbon and the carbonate content and the abundance of the $\underline{G}$. menaidii complex (Figure 41 and 42). Averages for organic carbon were computed for the Holocene and the $\mathrm{x}_{1}, \mathrm{x}_{3} ; \mathrm{x}_{5}$, and $\mathrm{x}_{7}$ zones - warm intervals - and for the Wturm $I$ and II and the $x_{2}, x_{4}$, and $x_{6}$ zones - cool intervals (Table 2). Cool periods are generally characterized by considerably higher organic carbon 
Figure 40. Vertical distribution of clay minera1s within five cores from the eastern Angola Basin. 


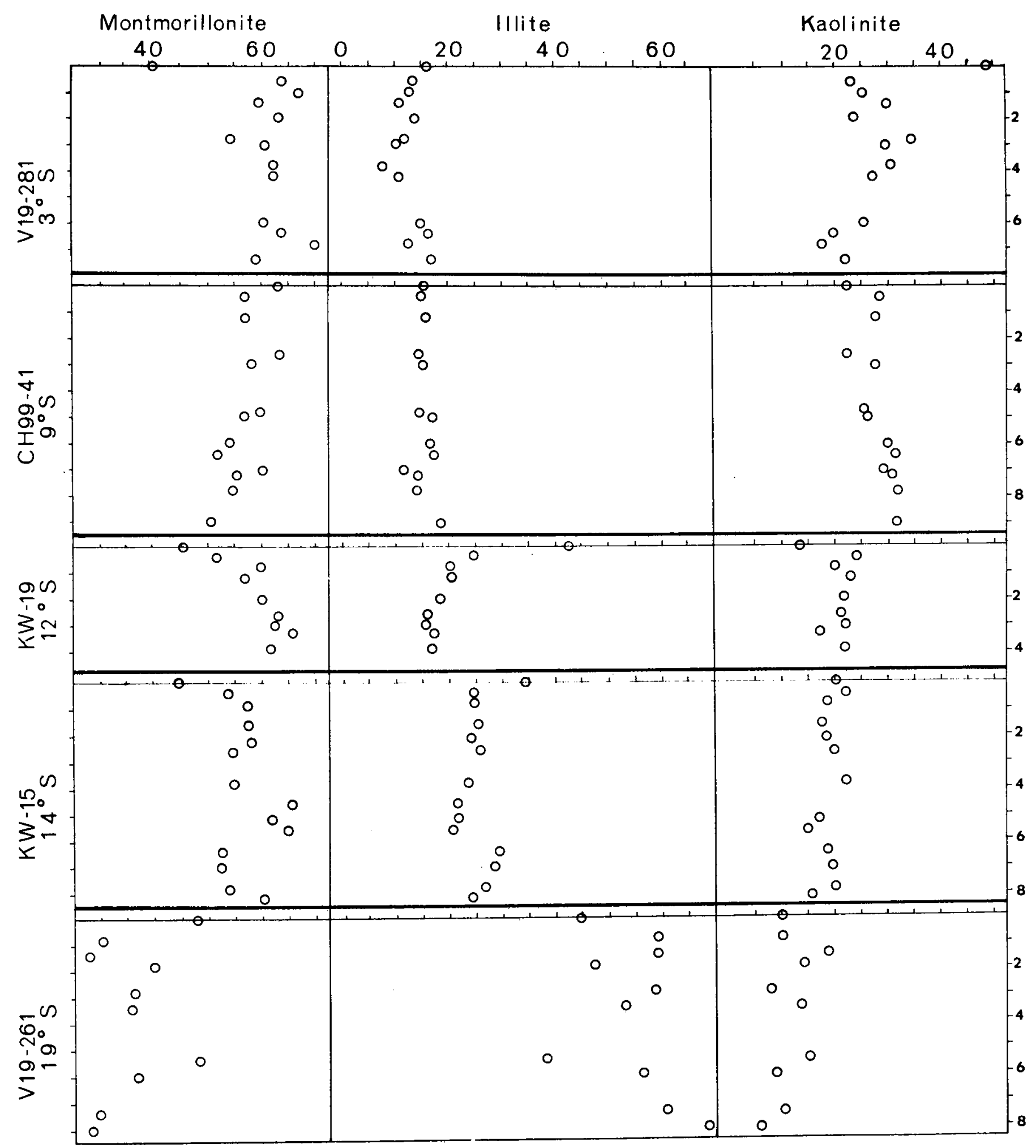

Figure 40 
Figure 41. Relationship between percent organic carbon and the calcium carbonate content of the silt and clay fraction and the abundance of G. menardii for cores V19-262, KW-19, and V19-281. 


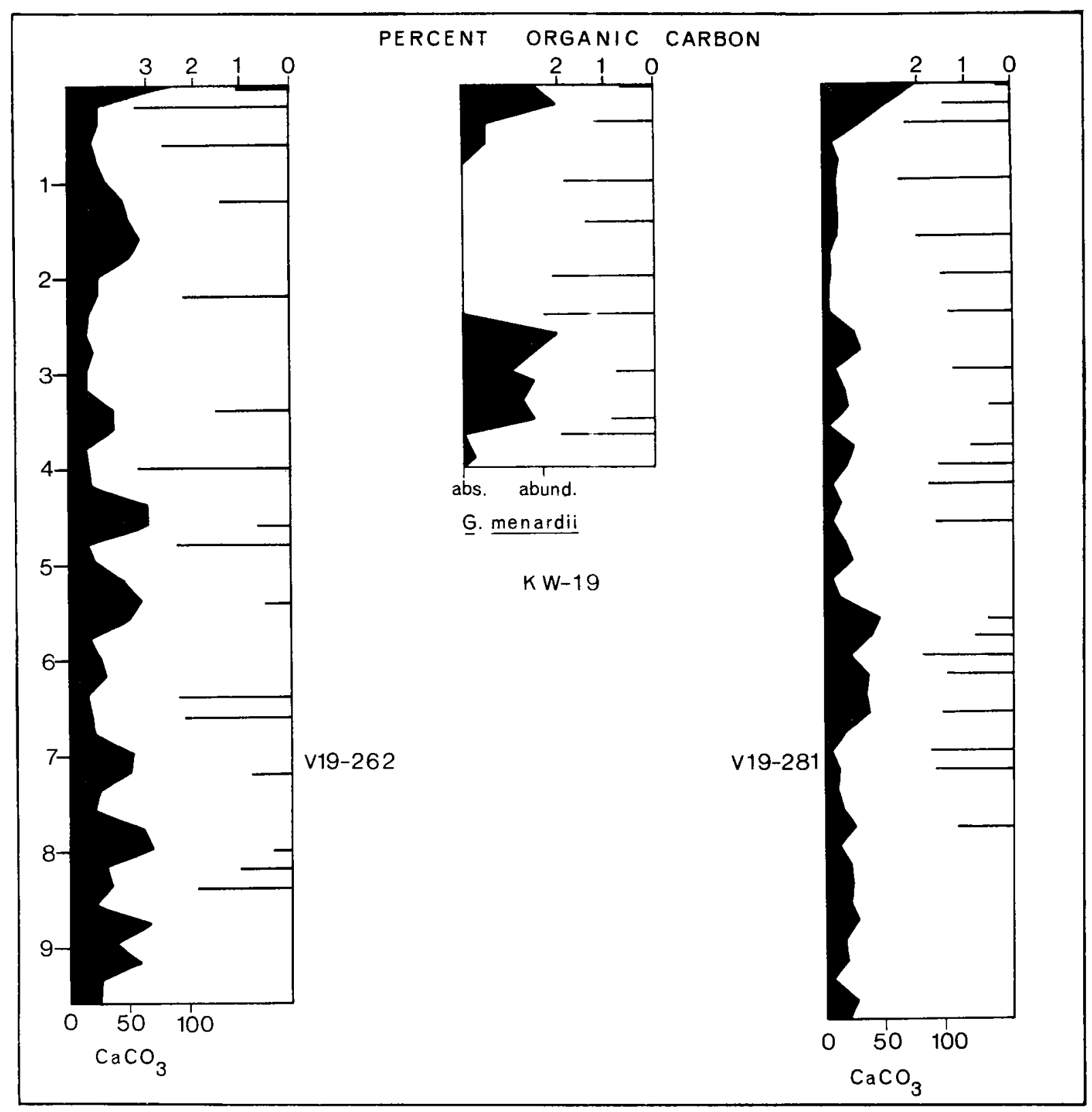

Figure 41 
Figure 42. Graphs of percent organic carbon versus calcium carbonate content of the silt and clay fraction for V19-262 and V19281 from the northern and southern parts of the Basin. 


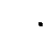

, 


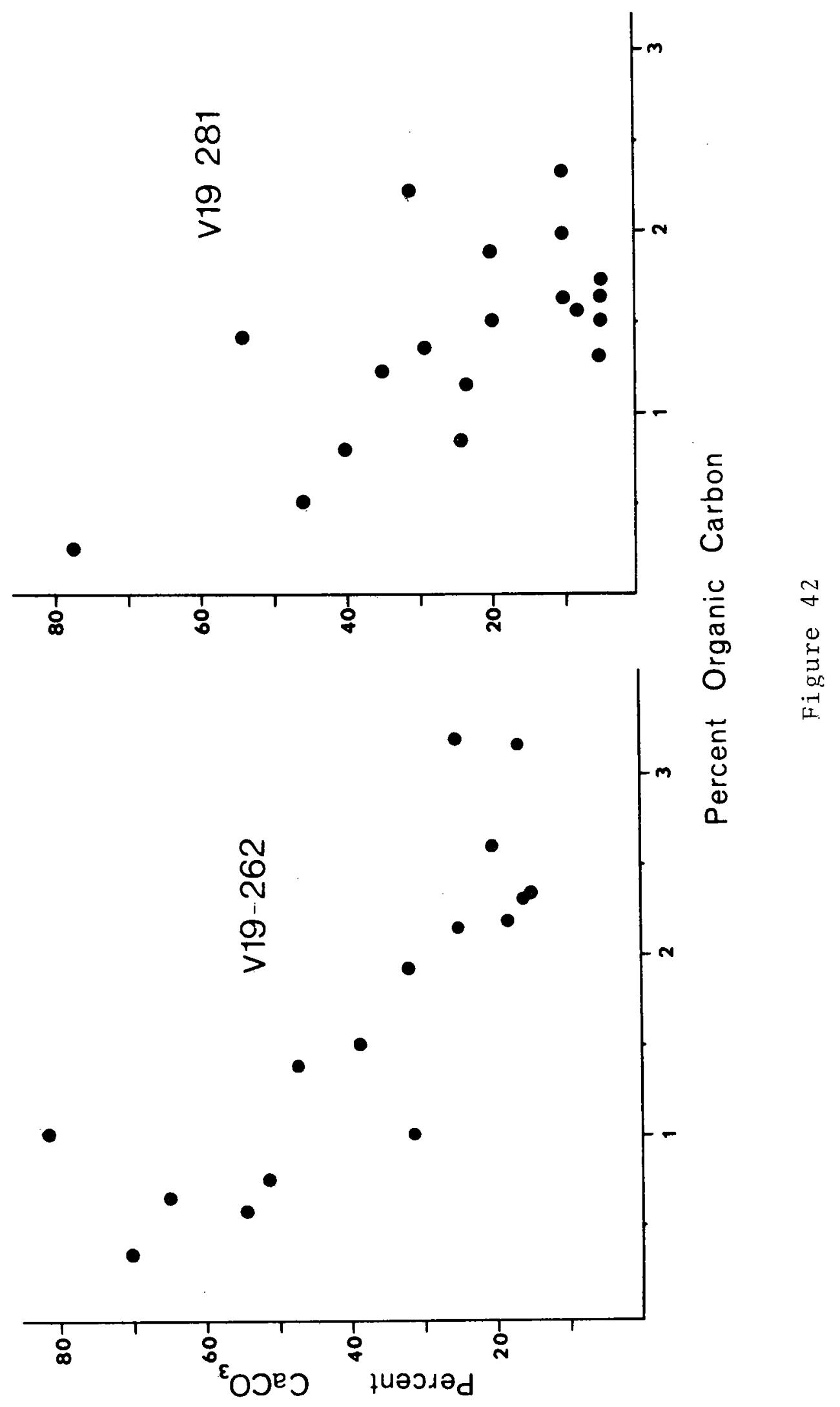


values than warm periods, averaging from 0.8 to $1.4 \%$ higher. This difference between warm and cool intervals was shown by a Student's t-test to be significant at the $95 \%$ confidence leve 1 .

Organic carbon values measured in these Angola Basin cores in general are much higher than thos e reported elsewhere on continental rises, particular1y sediments deposited during glacial and cool periods (Table 2). Stevenson and Cheng (1972) demonstrated differences between warm and cool intervals in the Argentine Basin similar to those described here, but their highest measured values were $1.6-1.7 \%$ as opposed to $3.2 \%$ in the Angola Basin. Froelich et a1. (1971) also showed higher organic carbon values corresponding to low carbonate zones in cores from the continental rise off Cape Hatteras, though their maximum values were only about $1.5 \%$. The higher organic carbon values corresponding to low carbonate values in the Angola Basin can be attributed to the inferred higher surface productivity and estimated bottom conditions conducive to its preservation. The latter will be discussed in more detail in a later section. 
TABLE 2.

AVERAGE PERCENT ORGANIC CARBON IN

GIACTAL AND INTERGLACIAL SECTIONS OF ANGOLA BASIN CORES

$\begin{array}{lcc}\text { Core } & \text { Cool Interva1s }(\%) & \text { Warm Intervals (\%) } \\ \text { V19-262 } & 2.27 & 0.88 \\ \text { V19-280 } & 2.28 & 1.24 \\ \text { V19-281 } & 1.80 & 0.98 \\ \text { KW-19 } & 1.90 & 0.90\end{array}$


The northern and central parts of the Angola Basin derive fine sediment mainly from the Congo River system. As Shepard and Emery (in press) indicate, the Congo River is unique in that its submarine canyon originates over $21 \mathrm{~km}$ inland from the river mouth. Thus, virtually all of the river's bed-1oad is delivered to the deep-sea, in contrast to other large tropical river systems, such as the Amazon, whose sediment is mainly dispersed along the adjacent continental shelf by longshore currents. The large lobe of kaolinitic sediment over the Congo cone and Angola abyssal plain, in the northern and central regions of the Angola Basin, reflects the source of sediment in the Congo Basin and its delivery to the deep sea through the Congo Canyon system. As we11, suspended matter dispersal follows a similar areal pattern: kaolinitic sediment is carried in suspension between 200 and $300 \mathrm{~km}$ from the river mouth where it becomes entrained in a complex surface current system. The Angola Current carries this sediment southwards over the central part of the eastern Angola Basin and 1ongshore currents carry suspended sediment northwards along the coast of Gabon into the southern Gulf of Guinea.

At the present time the contribution of fine sediment to the southern Angola Basin is primarily accomplished by the northward transport in suspension of illitic and montmorillonitic material mainly from South West Africa in the Benguela Current system. Both the Orange and the Kunene Rivers are undoubtedly important contributors of fine sediment to the Benguela Current and ultimately to the Angola Basin; Emel'ianov ard Senin (1969), however, point out that much of the Orange River sediment load is retained on the South West African shelf and is not carried very far northwards. 
Thus, although its suspended load is only one tenth that of the Orange $\left(15 \times 10^{6}\right.$ tons/yr versus $153 \times 10^{6}$ tons/yr), the Kunene River represents a very important source of terrigenous sediment in the southern Angola Basin. In addition, eolian transport of sediment is important in the delivery of fine sediment both directly to the Angola Basin and to the Bengue la Current which then carries it northward into the basin (Emel'ianov and Senin, 1969).

During interglacials, high organic productivity was restricted to the continental margin along South West Africa and did not extend very far into the Angola Basin. The highest concentrations and diversities of diatoms, seen in suspended matter samples, were found south of Lat. $15^{\circ} \mathrm{S}$ where the Benguela Current begins to leave the coast. Farther north, the eastward incursion of the South Equatorial Countercurrent brings unproductive water over much of the Angola Basin as shown by the impoverished diatom floras observed in suspended matter samples between latitudes $8^{\circ}$ and $15^{\circ} \mathrm{S}$; this water is distributed both southward by the Angola Current and northward by longshore currents along the coast of Gabon into the southern Gulf of Guinea. The general sterility of water masses over most of the Angola Basin is interrupted only where major rivers, such as the Congo, deliver sufficient nutrients to support small localized areas of higher primary productivity. The relatively low organic carbon values in surface sediments and in sediments from interglacial intervals (average 1.0\%) throughout the basir reflects this distribution of primary productivity.

At the present time there appears to be very little lateral transport of fine sediment within the deep basin. Suspended matter concentrations from deep stations taken during the WALDA expedition display a linear 
decrease with depth and do not suggest the presence of any nepheloid layers ahove $4500 \mathrm{~m}$. Nephelometer studles (Connary nnd Ewing, 1972), bottom photographs (Heezen et al., 1964), and geostrophic current calculations (WUst, 1957) also support the view that very little lateral sediment dispersal is presently occurring in the deep Angola Basin. On the other hand, the presence of continental rise swe11s off southern Angola and the lack of any decipherable trends within the clay-mineral distribution pattern within the late Quaternary suggests that bottom circulation must have been intensified previously, probably during glacial periods.

Climatic deterioration during the late Cenozoic apparently had a significant effect on oceanographic conditions, both surface and deep, and thereby on the nature of marine sedimentation throughout the world ocean. Watkins and Kennett $(1971,1972)$, Kennett and Brunner (1973), and Hayes et al. (1973) have shown that the growth of Antarctic continental glaciation, beginning in the Miocene, led to marked1y increased rates of bottom water production and to erosion and non-deposition in parts of the Southern Ocean. Farther to the north, Johnson (1972) showed that erosion in the equatorial Pacific by northward-flowing bottom water began during the late Cenozoic. Emery and others (in prep.) account for the presence of continental rise swe11s along the southern flank of the Walvis Ridge and the South West African continental rise and for the dissection of the western Cape abyssal plain by the flow of Antarctic Bottom Water, possibly commencing in the late Cenozoic. Fluctuations in the rate of production and the effects of this bottom water would be expected to have occurred during the Quaternary in response to the advance and retreat of continental ice sheets (Gordon, 1971). The observed topographic features on the continental rise in the southern 
Angola Basin can be accounted for by the influx of bottom water during. glacial intervals, periods of greater bottom water production. This proposed change in deep circulation is consistent with the model discussed below (and schematically shown in Figure 43), based on geochemical and compositional changes within cores, which attempts to account for the variations in volume and nature of bottom water during the late Quaternary in the Angola Basin.

At present time virtually no bottom water enters the Angola or Guinea Basins. The sill depth (3750 m) (Metcalf et al., 1964) of the equatorial At lantic region is slightly above the upper level of bottom water in the western South Atlantic (Figure 11) and only a very small volume of water passes into the Guinea Basin where it is quickly mixed and loses its identity (Metcalf et al., 1964). During glacial intervals, however, the greater production of bottom water would have raised the level above sill depth, permitting the continuous flow of bottom water into the eastern basins; this influx would have continued until the level again fell below sill depth (during interglacials) (Figure 43). A rise in the level of bottom water in the western equatorial Atlantic of only one to two hundred meters could conceivably have led to the emplacement of a layer of bottom water up to several hundred meters thick in the Angola and Guinea Basins. The intensity of deep circulation would have diminished following a glacial maximum, as less bottom water of progressively lower density would enter the Angola Basin.

In addition to creating a more intense circulation scheme, greater production of bottom water during glacial intervals also probably had an important effect both on the leve1 of the lysocline in the Angola Basin and on 

Figure 43. Schematic interpretation of bottom conditions in the Angola Basin during (a) glacial maxima; (b) an intermediate stage of warmer climate; and (c) interglacial maximum. (See text for further explanation of the model). 

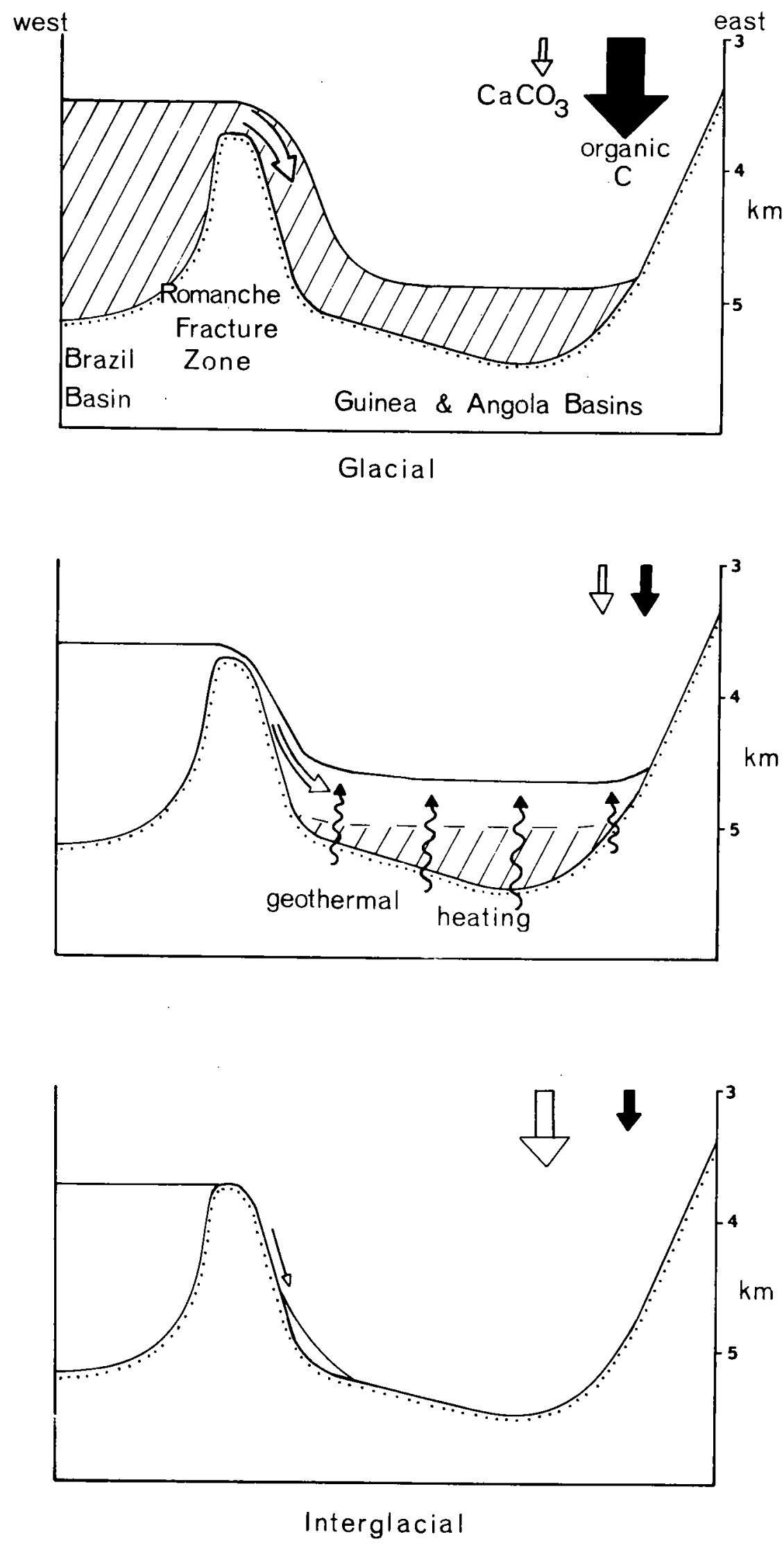

Figure 43 
the extent of reducing conditions on the sea floor. As Worthington (1968) suggested, bottom water derived during the coldest periods would be of hig her salinity and slightly lower temperature than that forming today. This dense water $(1.0286-1.0287)$ would fill the deeper parts of the sea floor and, subsequent to a glacial maximum, become nearly stagnant since its upward displacement could only be effected through geothermal heating. This vertical mixing could take several thousand years, during which time oxygen leve1s would be depleted and carbon dioxide levels would be increased leading to greater rates of solution of carbonate on the sea floor. The increased rate of production of bottom water during glacials would result in a much greater influx of corrosive water through the Romanche Fracture Zone into the Guinea and Angola Basins. This dense water, which was probably initia1ly more undersaturated with respect to calcite than present bottom water (Berger, 1968) remained in the deepest parts of these eastern basins unti1 mixed with the overlying water.

Berger deduced that the lysocline presently 1 ies at approximately 4700 meters depth in the northern Angola Basin and at 5200 meters in the south. This latter figure is about $800 \mathrm{~m}$ deeper than the leve1 in the Brazil Basin (Figure 44). The severe reduction in carbonate observed in the deep-sea cores from the Angola Basin suggests that the lysocline was at least 500 to 600 meters shallower during glacials than interglacials. Based on Worthington's (1968) estimate of the geothermal mixing rate of "climax bottom water" (15, 000 years for a layer $1000 \mathrm{~m}$ thick), it would require approximately 7,500 to 9,000 years to completely mix a layer of this water 500 to 600 meters thick in the Angola Basin. Since only a part of the bottom water entering the basin during glacials would be of this type, however, this 
Figure 44. Depth of the lysocline (m) in the equatoria1 South Atlantic (after Berger, 1968). 



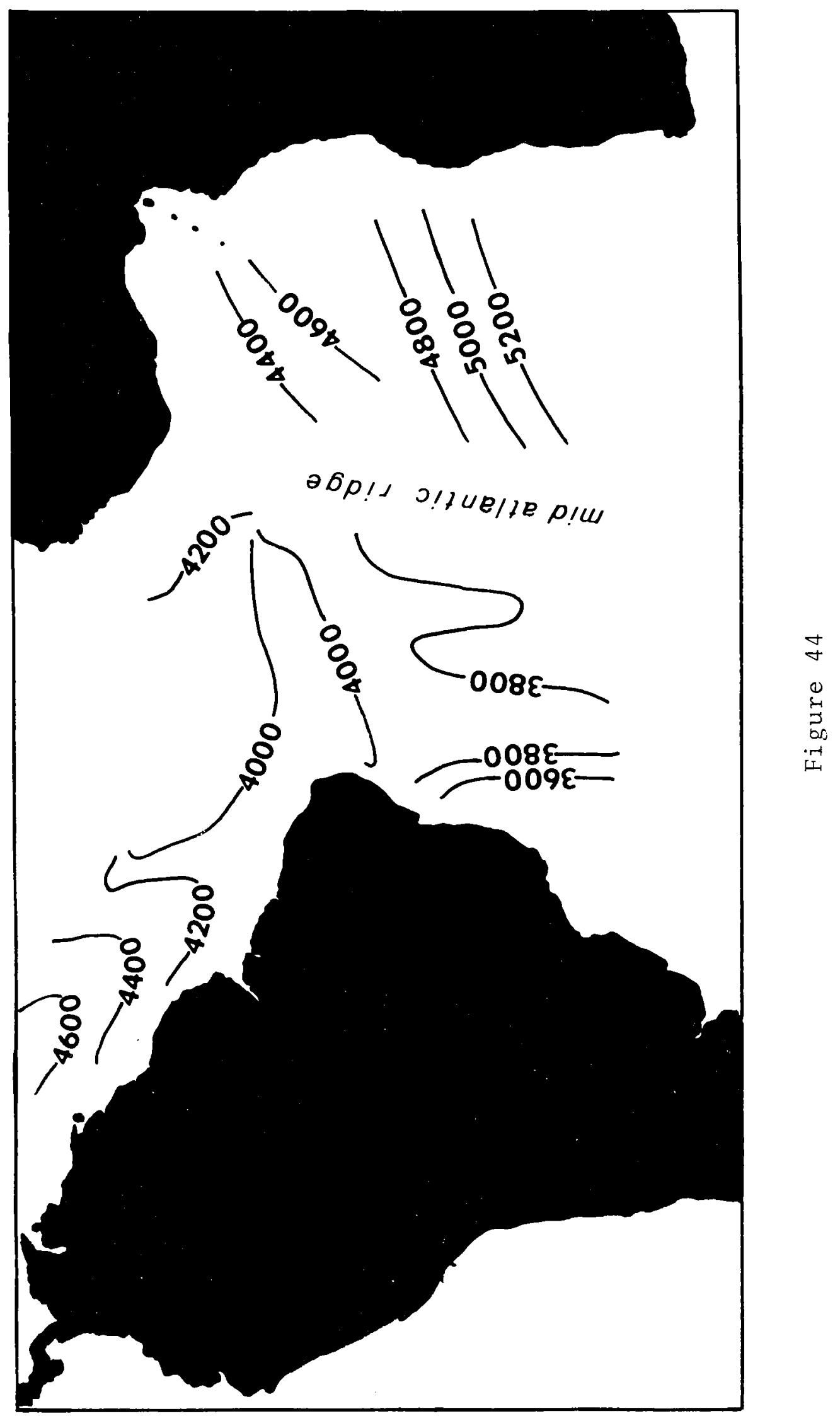


estimate is probably too high. Based on sedimentation rates inferred for Angola Basin cores and changes in carbonate content, a period of between 4,000 and 6,000 years would be sufficient to destroy the layer of bottom water derived during glacials.

More reducing conditions in the Angola Basin would have developed in response to changes in both bottom circulation and surface oceanographic conditions. van Zinderen Bakker (1967) deduced that the Benguela Current, and its associated upwelling, extended northward into the Angola Basin during glacials as a consequence of the northward displacement of the South Atlantic Anticyclone. As we11, upwelling was initiated along the suitably aligned section of the coast between Luanda, Angola, and Gape Lopez. Both of these changes in surface oceanographic conditions led to greater surface productivity and to the delivery of great amounts of organic matter to the sea floor in the eastern Angola Basin. As a result, organic carbon levels from glacial sections of Angola Basin cores are approximately twice those from interglacial sections. van Andel and Calvert (1971) suggested that the Benguela Current was intensified during glacials in order to account for the erosion they observed on the South West African shelf; this would have led to greater upwelling and higher influx of organic matter into the Angola and Cape Basins.

The increased delivery of organic matter resulted in higher benthic productivity as shown by the greater abundance of fecal pellets and burrows during glacials. Higher benthic productivity, in turn, would have reduced oxygen levels and increased carbon dioxide levels, thereby lowering $\mathrm{pH}$ and facilitating the production of pyrite which is commonly found in these sections of the cores. The rate at which reducing conditions developed pro- 
bably increased markedly following the height of glaciation as bottom water became isolated in the deeper parts of the basin.

With regard to the Peru Current, Berger (1970) concluded that greater than average solution of calcium carbonate would be expected in response to the rapid delivery of organic matter to the sea floor. The observed drastic reduction in carbonate during glacials in the deep Angola Basin is in agreement with Berger's findings. The undersaturation of bottom water with respect to calcite during glacials would be maintained not only by the increased influx of organic matter, however, but also through the decreased rate of carbonate input. This is shown by the very marked shift from a dominantly foraminiferal plankton assemblage in interglacials to a more radiolartan assemblage during glacials in cores from we11 above the lysoc1ine. This change is undoubtedly a result of colder water being brought to the surface during glacials by the upwelling in the Benguela Current and along northern Angola, Congo, and Gabon. Thus, the greater solution of carbonate during glacial intervals was not only effected through the influx of cold, corrosive bottom water, but also through the increased rate of supply of organic matter and the decreased rate of carbonate input (Figure 43).

Previous investigators have emphasized the importance of terrigenous dilution in the reduction of carbonate contents of glacial sections of cores from the equatorial Atlantic. The relatively uniform pelagic sedimentation rates inferred for the Angola Basin throughout the late Quaternary do not support the concept that terrigenous dilution is the dominant controlling fact or in this area. Based on work on land by dePloey (1963, 1964, 1965) and Fairbridge (1964) there is considerable evidence that, in fact, the Congo discharge was probably less during glacials than at present and that its sediment load was at most the same. Although glacial aridity in the lower 
Congo Basin led to higher rates of physical weathering, the more readily available sediment was apparently not removed to the deep sea in appreciably greater quantities than at present. This is in marked contrast to the model which Damuth and Fairbridge (1970) proposed for the Amazon-Guiana Basin system. Glacial aridity in northeastern South America resulted in deforestation and hence in greater physical weathering and erosion and a much higher transport of sediment to the deep sea. The Amazon, fed by Andean glaciers, had a much higher discharge during glacials than interglacials. Changes in carbonate content in cores from the Angola Basin can be accounted for by variations in surface carbonate productivity and by changes in sea-floor solution of carbonate tests resulting from fluctuations in bottom water conditions. 
CONCLUSIONS

Sedimentation in the eastern Angola Basin throughout the late Quaternary has been strongly influenced by the prevailing climatic and the oceanographic regimes, both surface and abyssal. High rainfall in modern equatorial west Africa leads to large fluvial sediment input from the Congo and other tropical rivers and results in high sedimentation rates over much of the continenta1 margin. During glacia1 interva1s the onset of arid and semi-arid conditions on the adjacent land areas led to higher rates of physical weathering. The overall lower river discharge during these periods, however, prevented appreciably greater volumes of sediment from being transported to the Angola Basin, as evidenced by the relatively uniform sedimentation rates throughout the Quaternary.

At the present time high surface productivity is restricted to the waters south of the Angola Basin and is associated with the northward flowing cold Benguela Current. During cooler periods of the Quaternary, however, the northward extension of the Benguela Currant along the coast of Angola and the onset of upwelling off Congo and Gabon resulted in much greater surface productivity and led to organic-rich sediments on the underlying continental margin and to higher benthic productivity. A shift from calcareous to more siliceous biogenic components also occurred in response to this change in surface oceanography.

At present very little bottom water enters the eastern basins of the South Atlantic resulting in a deep lysocline, the widespread accumulation of calcareous sediments over much of the area, and very sluggish deep circulation. During glacial maxima, however, much more bottom water flowed into and filled the deeper parts of the Guinea and Angola Basins. This corrosive 
water significantly raised the lysocline, leading to the dissolution of carbonate at depths which are presently dominated by calcareous sediments. The more vigorous deep circulation during glacials also created continental rise hills along southern Angola and the Walvis Ridge. The isolation of this "climax bottom water" in the Angola and Guinea Basins during warmer periods resulted in the gradual onset of reducing conditions, the preservation of organic-rich sediments, and the development of authigenic sulfide minerals. This condition persisted until the "old" bottom water could be mixed, primarily by geothermal heating, with the overlying water mass.

The model proposed to explain the changes in sedimentation during the late Quaternary in the Angola Bas in may find profitable application in other restricted basins in the world ocean. 
REFERENCES

Arrhenius, G., 1952, Sediment cores from the East Pacific: Swedish Deep-sea Expedition. (1947-48) Repts., v. 5, 89 p.

Baumgartner, T.R. and van Ande1, Tj.H., 1971, Diapirs of the continental margin of Angola, Africa: Geo1. Soc. Amer. Bul1., v. 82, p. 793-802.

Berger, W.H., 1968, Planktonic foraminifera: selective solution and paleoclimatic interpretation: Deep-Sea Res., v. 15, p. 31-43. , 1970, Planktonic foraminifera: selective solution and the lysocline: Marine Geology, v. 8, p. 111-138.

Berthois, L., Crosnier, A. and le Calvez, Y., 1968, Contribution a l'étude sédimentologique du plateau continental dans la baie de Biafra: Cah. O.R.S.T.O.M., sér. océanogr., IV, p. 55-66.

Biscaye, P.E., 1964, Distinction between kaolinite and chlorite in Recent sediment by X-ray diffraction: Am. Mineralogist, v. 49, p. 1281-1289. , 1965, Mineralogy and sedimentation of Recent deep-sea clay in the Atlantic Ocean and adjacent seas and oceans: Geol. Soc. Amer. Bu11., v. 76, p. 803-832.

Bornhold, B.D., Mascle, J.R. and Harada, K., 1973, Suspended matter in surface waters of the eastern Gulf of Guinea: Marine Geology, in press. Broecker, W.S., 1971, Calcite accumulation rates and glacial to interglacial changes in oceanic mixing: in Turekian, K. (ed.), Late Cenozoic Glacial Ages, Yale Univ. Press, New Haven, p. 239-265. and van Donk, J., 1970, Insolation changes, ice volumes, and the $0^{18}$ record in deep-sea cores: Reviews of Geophysics and Space Physics, v. 8, p. 169-197. Capart, A., 1951, Liste des Stations. Expédition Océanographique Belge dans 
les Eaux Côtières Africaines de 1'Atlantique Sud (1948-1949): Institut Royal des Sciences Naturelles, de Belgique.

Chester, R., Elderfield, H., Griffin, J.J., Johnson, L.R. and Padgham, R.C., 1972, Eolian dust along the eastern margins of the Atlantic Ocean: Marine Geology, v. 13, p. 91-105.

Connary, S.D. and Ewing, M., 1972, The nepheloid layer and bottom circulation in the Guinea and Angola Basins: in A.L. Gordon (ed.), Studies in Physical Oceanography, Gordon and Breach, London.

Cooke, H.B.S., 1947, The development of the Vaal River and its deposits: South African Geo1. Soc., Trans., v. 49, p. 243-259.

Damuth, J.E. and Fairbridge, R.W., 1970, Equatorial At lant ic deep-sea arkosic sands and ice-age aridity in tropical South America: Geol. Soc. Amer. Bu11., v. 81, p. 189-206.

DeDecker, A.H.B., 1970, An oxygen-depleted sub-surface current off the west coast of South Africa: Invest1. Rept. Div. Sea Fisheries, South Africa, No. 84,24 p.

de P1oey, J., 1963, Quelques indices sur 1'evolution morphologique et paléoclimatique des environs du Stanley-Pool (Congo): "Lovanium," Fac. Sc., v. $17,16 \mathrm{p}$. , 1964, Cartographie géomorphologique et morphogenèse aux environs du Stan1ey-Poo1 (Congo): Acta Congr. Lovanienșa, v. 3, p. 431-441. , 1965, Positions géomorphologique, genèse et chronologie de certains depots superficiels au Congo occidental: Quaternaria, VII, p. 131-154.

Donguy, J.-R., Hardiville, J. and LeGuen, J.C., 1965, Le parcours maritime des eaux du Congo: Cahiers Océanographiques, v. 17, p. 85-97. 
Fairbridge, R.W., 1964, African ice-age aridity: in A.E.M. Nairn (ed.), Problems in Paleoclimatology, Interscience, p. 356-374.

F1int, R.F., 1959, Pleistocene c1imates in eastern and southern Africa: Geol. Soc. Amer. Bu11., v. 70, p. 343-374.

Froelich, P., Golden, B., and Pilkey, O.H., 1971, Organic carbon in sediments of the North Carolina continental rise: Southeastern Geol.,v. 13, p. 9197.

Fuglister, F.C., 1961, Atlantic Ocean atlas of temperature and salinity profiles and data from the International Geophysical Year 1957-1958: Atlas Ser., Woods Hole Oceanographic Institution, 1.

Gallardo, Y., Crosnier, A., Gheno, Y., Guillerm, J.M., LeGuen, J.C. and Rebert, J.P., 1969, Resultas hydrologiques des campagnes du Centre O.R.S.T.O.M. de Pointe Noire (Congo-Brazza) devant I'Angola, de 1965 a 1967: Cah. Oceanographiques, v. 21, P. 584-593 and 387-400. Giresse, P., 1965, 0o1ithes ferrugineuses en voie de formation au large du Cap Lopez (Gabon): C.R. Acad. Sci., v. 260, p. 2550-2552. , 1969, Etude des differents grains ferrugineux authigenes des sediments sous-marins ar large du delta de l'Ogooue (Gabon): Science de la Terre, v. 14, p. 27-62. and Kouyoumontzakis, G., 1971, Rapport de la mission effectuee par la Laboratoire de Geologie du Centre d'Enseignement superieur de Brazzaville a bord du "Nizery" du 2 au 5 juin 1971: O.R.S.T.O.M., Duc. no. 517 SR, Centre: de Pointe Noire, 5 p.

Goldberg, E.D. and Griffin, J.J., 1964, Sedimentation rates and mineralogy in the South Atlantic: Jour. Geophys. Res., v. 69, p. 4293-4309. 
Gordon, A.I., 1971, Oceanography of Antarctic waters: in J.L. Reid (ed.), Antarctic Oceanology I, Antarctic Res. Series, v. 15, p. 169-203.

Hart, T.J. and Currie, R.I., 1960, The Benguela Current: Discovery Reports, v. 31, p. 123-298,

Hayes, D.E. and others, 1973, Leg 28 deep-sea drilling in the southern Ocean: Geotimes, v. 18, p. 19-24.

Hays, J.D. and Perruzza, A., 1972, The significance of calcium carbonate oscillations in eastern equatorial Atlantic deep-sea sediments for the end of the Holocene warm interva1: Quaternary Res., v.2, p. 355-362.

Imbrie, J. and Kipp, N., 1971, A new micropaleontological method for quantitative paleoclimatology: application to a late Pleistocene Caribbean core: in K. Turekian (ed.), Late Cenozoic Glacia1 Ages, Yale Univ. Press, New Haven, Conn.

Johnson, D.A., 1972, Ocean-floor erosion in the equatorial Pacific: Geol. Soc. Amer. Bu11., v. 83, p. 3121-3144.

Jones, N., 1944, The climatic and cultural sequence at Sawmil1s, Southern Rhodesia: Southern Rhodesia Nat1. Museum, Occ. Papers, v. 2, p. 39-46. Kennett, J.P. and Brunner, C.A., 1973, Antarctic late Cenozoic glaciation: Evidence for initiation of ice-rafting and inferred increased bottomwater activity: Geol. Soc. Amer. Bull., v. 84, p. 2043-2052. and Huddlestun, P., 1972, Late Pleistocene paleoclimatology, foraminiferal biostratigraphy, and tephrachronology, western Gulf of Mexico: Quaternary Research, v. 2, p. 38-69.

Landsberg, H.E., Lippman, H., Paffen, Kh., and Tro11, C., 1963, World Maps of Climatology: Springer-Verlag, Gottingen-Heidelberg, 28 pp. Lavrov, V.M. and Save1'yeva, K.P., 1972, Deep-water sediments in the Guinea 
Basin: Oceanology, v. 12, p. 551-562.

Leakey, L.S.B., 1949, Tentative study of the Pleistocene climatic changes and stone-age culture sequence in northeastern Angola: Diamang Publ. Cultur., Mus. Dondo, iv.

LePichon, X. and Hayes, D.E., 1971, Margina1 offsets, fracture zones, and the opening of the South Atlantic: Jour. Geophys. Res., v. 76, p. 6283-6293. Leyden, R., Bryan, G., and Ewing, M., 1972, Geophysica1 reconnaissance on African shelf: 2. Marginal sediments from Gulf of Guinea to Walvis Ridge:

Lidz, L., 1966, Deep-sea Pleistocene biostratigraphy: Science, v. 154, p. 14481452.

Manheim, F.T., Meade, R.H., and Bond, G.C., 1970, Suspended matter in surface waters of the Atlantic continental margin from Cape Cod to the Florida Keys: Science, v. 167, p. 371-376.

Mascle, J.R., Bornhold, B.D., and Renard, V., in press, Diapiric structures off the Niger delta: Bul1. Amer. Assoc. Petrol. Geol.

McIntyre, A. and Ruddiman, W.F., 1972, Northeast Atlantic Post-Eemian paleooceanography, a predictive analog of the future: Quaternary Research, v. 2 , p. 350-354.

Mesole1la, K.J., Matthews, R.K., Broecker, W.S., and Thurber, D.L., 1969, The astronomical theory of climatic change: Barbados data: Jour. Geol., v. 77, p. $250-$

Metcalf, W.G., Heezen, B.C., and Stalcup, M.C., 1964, The sill depth of the Mid-Atlantic Ridge in equatorial regions: Deep-Sea Res., v. 11, p. 1-10. Moreau, R.E., 1933, Pleistocene climatic changes and the distribution of life in East Africa: Jour Ecology, v. 21, p. 415-435. 
Moroshkin, K.V., Bubnov, V.A., and Bulatov, R.P., 1970, Water cfrculation in the eastern South Atlantic Ocean: Oceanology, v. 10, p. 27-37.

Payne, R.R. and Conolly, J.R., 1972, Turbidite sedimentation off the Antarctic continent: in D.E. Hayes (ed.), Antarctic Oceanology II, The AustralianNew Zealand Sector, Antarctic Res. Series, v. 19, American Geophys. Union. Porrenga, D.H., 1965, Clay minerals in Recent sediment of the Niger delta: Clays and Clay Mine rals, Proc. 14th Clay Conf., p. 221-233.

Pratje, 0., 1935, Die sedimente des Sudatlantischen Ozeans: Wiss. Ergeb. dt. At1. Exped. Meteor 1925-1927, iii, 2, p. 1-171.

Rabinowitz, P.D., 1972, Gravity anomalies on the continental margin of Angola, Africa: Jour. Geophys. Res., v. 77, p. 6327-6347.

Ruddiman, W.F., 1971, Pleistocene sedimentation in the equatorial At lantic: stratigraphy and faunal paleoclimatology: Geol. Soc. Amer. Bull., v. 82, p. 283-302.

Schott, W., 1935, Die Foraminiferan in dem äquatorialen Teil des Atlantischen Ozeans: Wiss. Ergeb. dt. At1. Exped. Meteor 1925-1927, iii, 3, p. 43-134. Sche11, I.I., 1968, On the relation between winds off Southwest Africa and the Benguela Current and Aghulhas Current penetration in the South Atlantic: Deutsche Hydrographische Zeitschrift, v. 21, p. 109-117.

Shepard, F.P. and Emery, K.0., in press, Congo submarine canyon and fan valley: Amer. Assoc. Petrol. Geol.

Shannon, L.V., and van Rijswijck, M., 1969, Physical Oceanography of the Walvis Ridge region: Invest1. Rept. Div. Sea Fisheries South Africa, No. 70 .

Steeman Nielsen, E. and Jensen, A.E., 1957, Primary oceanic production: Galathea Repts., v. 1, p. 47-136. 
Stevenson, F.J. and Cheng, C. - N., 1972, Organic geochemistry of the Argentine Basin sediments: carbon-nitrogen relationships and Quaternary correlations: Geochim. et Cosmochim. Acta, v. 36, p. 653-671.

Uchupi, E., 1972, Bathymetric Atlas of the Atlantic, Caribbean and Gulf of Mexico: Woods Hole Oceanographic Institution, Ref. No. 71-72, 10 p. van Ande1, Tj.H. and Calvert, S.E., 1971, Evolution of sediment wedge, Walvis she1f, Southwest Africa: Jour. Geol., v. 79, p. 585-602.

van der Merwe, C.R., 1966, Soil groups and sub-groups of South Africa: Dept. Agr. Techn. Serv. Science, Publ. 231, 353 p.

van Zinderen Bakker, E.M., 1963, Analysis of pollen samples from northeast Angola: in J.D. Clark (ed.), Prehistoric Cultures of Northeast Angola and Their Siginificance in Tropical Africa: Part I, Museo do Dondo, p. 213-217. 1966, The pluvial theory - an evaluation in the light of new data, especially for Africa: the Paleobotanist, v. 15, p. $128-134$. , 1967, Upper Pleistocene and Holocene stratigraphy and ecology on the basis of vegetation changes in sub-Saharan Africa: in W.W. Bishop, and J.D. Clark (eds.), Background to Evolution in Africa, Univ. Chicago Press, p. 125-147. , 1969, Reconstruction of Quaternary climates: $\underline{\text { in }}$ E.M. van Zinderen Bakker (ed.), Paleoecology of Africa, v. iv, Balkema, Cape Town. and Clark, J.D., 1962, Pleistocene climates and cultures northeastern Angola: Nature, v. 196, p. 639-642. and Coetzee, J.A., 1972, Reappraisal of late 
Quaternary climatic evidence from tropical Africa: in E.M. van Zinderen Bakker (ed.), Paleoecology of Africa, the Surrounding Islands and Antarctica, vii, Balkema, Cape Town.

von Herzen, R.P., Hoskins, H., and van Ande1, Tj.H., 1972, Geophysica1 studies on the Angola diapir field: Geol. Soc. Amer. Bul1., v. 83, p. 1901-1910. Voss, F., 1970, Kaltzeitliche Ablagerungen im Hochland von Angola: Eiszeitalter u. Gegenwart, v. 21, p. 145-160.

Watkins, N.D. and Kennett, J.P., 1971, Antarctic bottom water: a major change in velocity during the late Cenozoic between Australia and Antarctica: Science, v. 173, p. 813-818. and , 1972, Regional sedimentary disconformities and upper Cenozoic changes in bottom water velocities between Australia and Antarctica: Amer. Geophys. Union, Antarctica Res. Series, v. 19, p. 273-293.

Worthington, L.V., 1968, Genesis and evolution of water masses: Meteorological Monogr., v. 8, p. 63-67. and Wright, R., 1970, Nuith Atlantic Ocean Atlas of Potential Temperature and Salinity in the Deep Water: Woods Hole Oceanogra hic Institution, Atlas Series, 2. WUst, G., 1933, Das Bodenwasser und die Gliederung der Atlantischen Tiefsee: Wiss. Ergeb. dt. At 1. Exped. Meteor 1925-1927, vi, p. 1-107. , 1957, Stromgeschwindigkeiten und Strommengen in der Tiefen des Atlantishen Ozeans: "Meteor"-Werk, 6 (2), p. 261-420. Yeroshev-shak, V.A., 1961, Kaolinite in the sediments of the Atlantic Ocean: Dokl. Akad. Nauk SSSR, v. 137, p. 695-697. 
Duncan, J.R., Fowler, G.A., and Kulm, L.D., 1970, Planktonic foraminiferanradiolarian ratios and Holocene - late Pleistocene deep-sea stratigraphy off Oregon: Geo1. Soc. Amer. Bu11., v. 81, p. 561-566.

Emel'ianov, E.M. and Senin, Iu.M., 1969, Composition of the sediments of the South-west Africa she1f: Litologiia i poleznye iskopaemye, v. 2, p. 10-25. Emery, K.o., 1973, Eastern Atlantic continental margin: some results of the 1972 cruise of the R.V. "At lantis II": Science, v. 178, p. 298-301. , Hayashi, Y., Hilde, T.W.C., Kobayashi, K., Koo, J.H., Meng, C.Y., Niino, H., Osterbagen, J.H., Reyno1ds, L.M., Wageman, J.M., Wang, C.S., and Yang, S.J., 1969, Geologic structure and some water characteristics of the East China Sea and the Yellow Sea: Tech. Bull. Econ. Comm. Asia Far East, v. 2, p. 3-43. , Milliman, J.D. and Uchupi, E., 1973, Physial properties and suspended matter of surface waters in the southeastern Atlantic Ocean: Jour. Sed. Petrol, in press.

Emiliani, C., 1955, Pleistocene temperatures: Jour. Geo1., v. 63, p. 538-578. , 1964, Paleotemperature analysis of Caribbean cores A254-BR-C and CP.28: Geol. Soc. Amer. Bu11., v. 75, p. 129-144. , 1971, The last interglacial. Paleotemperatures and chronology: Science, v. 171, p. 571-573.

Ericson, D.B. and Wollin, G., 1956, Micropaleontological and isotopic determinations of Pleistocene climates: Micropaleontology, v. 2, p. 257-270. , Ewing, M., Wo11in, G., and Heezen, B.C., 1961, At lantic deepsea sediment cores: Geo1. Soc. Amer. Bul1., v. 72, p. 193-286.

Ewing, M., Ericson, D.B. and Heezen, B.C., 1958, Sediments and topography of the Gulf of Mexico: in L. Weeks (ed.), Habitat of Oil, Am. Assoc. Petrol. Geo1., p. 995-1053. 
APPENDIX I

Sample Locations 
SURFACE SAMPLES

Bureau of Commercial Fisheries

\begin{tabular}{|c|c|c|c|}
\hline Samp le Number & Latitude ${ }^{\circ} \mathrm{S}$ & Longitude ${ }^{\circ} \mathrm{E}$ & Depth (m) \\
\hline 94 & $16^{\circ} 27^{\prime}$ & $11^{\circ} 35^{\prime}$ & -- \\
\hline 96 & $16^{\circ} 41^{\prime}$ & $11^{\circ} 21^{\prime}$ & 162 \\
\hline 99 & $15^{\circ} 17^{\prime}$ & $11^{\circ} 57^{\prime}$ & 90 \\
\hline 101 & $17^{\circ} 01^{\prime}$ & $11^{\circ} 31^{\prime}$ & 18 \\
\hline 102 & $17^{\circ} 02^{\prime}$ & $11^{\circ} 40^{\prime}$ & 54 \\
\hline 103 & $17^{\circ} 06^{\prime}$ & $11^{\circ} 35^{\prime}$ & 90 \\
\hline 105 & $17^{\circ} 13^{\prime}$ & $11^{\circ} 27^{\prime}$ & 155 \\
\hline \multicolumn{4}{|c|}{ Congo Republic } \\
\hline 506 & $4^{\circ} 52^{\prime}$ & $11^{\circ} 46^{\prime}$ & 54 \\
\hline 513 & $4^{\circ} 57^{\prime}$ & $11^{\circ} 39^{\prime}$ & 94 \\
\hline 576 & $4^{\circ} 23^{\prime}$ & $11^{\circ} 08^{\prime}$ & 91 \\
\hline 585 & $4^{\circ} 12^{\prime}$ & $11^{\circ} 18^{\prime}$ & 16 \\
\hline 605 & $4^{\circ} 32^{\prime}$ & $10^{\circ} 56^{\prime}$ & 125 \\
\hline 615 & $5^{\circ} 01^{\prime}$ & $11^{\circ} 28^{\prime}$ & 118 \\
\hline 783 & $3^{\circ} 44^{\prime}$ & $10^{\circ} 04^{\prime}$ & 250 \\
\hline 791 & $3^{\circ} 37^{\prime}$ & $10^{\circ} 17^{\prime}$ & 80 \\
\hline 800 & $3^{\circ} 27^{\prime}$ & $10^{\circ} 33^{\prime}$ & 14 \\
\hline
\end{tabular}

Woods Hole Oceanographic Institution

(Sanders) (AII-42)

\begin{tabular}{|c|c|c|c|}
\hline 198 & $\begin{array}{r}10^{\circ} 24^{\prime} \\
9^{\circ} 47^{\prime}\end{array}$ & $\begin{array}{r}9^{\circ} 09^{\prime} \\
10^{\circ} 29^{\prime}\end{array}$ & $\begin{array}{l}4559 \\
4566\end{array}$ \\
\hline 200 & $\begin{array}{l}9^{\circ} 43.5^{\prime} \\
9^{\circ} 29^{\prime}\end{array}$ & $\begin{array}{l}10^{\circ} 57^{\prime} \\
11^{\circ} 34^{\prime}\end{array}$ & $\begin{array}{l}2644 \\
2754\end{array}$ \\
\hline
\end{tabular}


SURFACE SAMPLES

Woods Hole Oceanographic Institution

(Sanders) (AII-42)

\begin{tabular}{cccc} 
Sample Number & Latitude ${ }^{\circ} \mathrm{S}$ & Longitude ${ }^{\circ} \mathrm{E}$ & Depth (m) \\
\cline { 2 - 3 } 201 & $9^{\circ} 25^{\prime}$ & $11^{\circ} 35^{\prime}$ & 1964 \\
$9^{\circ} 05^{\prime}$ & $12^{\circ} 17^{\prime}$ & 2031 \\
202 & $8^{\circ} 56^{\prime}$ & $12^{\circ} 15^{\prime}$ & 1427 \\
& $8^{\circ} 46^{\prime}$ & $12^{\circ} 47^{\prime}$ & 1643 \\
203 & $8^{\circ} 48^{\prime}$ & $12^{\circ} 52^{\prime}$ & 527 \\
& & & 542
\end{tabular}

Woods Hole Oceanographic Institution

(AII-67)

$\begin{array}{lllr}5019 & 17^{\circ} 40^{\prime} & 11^{\circ} 38.5^{\prime} & 110 \\ 5022 & 17^{\circ} 15^{\prime} 3^{\prime} & 11^{\circ} 37.8^{\prime} & 88 \\ 5025 & 16^{\circ} 48^{\prime} & 11^{\circ} 37^{\prime} & 77 \\ 5030 & 16^{\circ} 15.7^{\prime} & 11^{\circ} 41^{\prime} & 49 \\ 5031 & 11^{\circ} 21.0^{\prime} & 13^{\circ} 38^{\prime} & 29 \\ 5034 & 11^{\circ} 04^{\prime} 5^{\prime} & 13^{\circ} 35.8^{\prime} & 132 \\ 5037 & 10^{\circ} 43.8^{\prime} & 13^{\circ} 31.2^{\prime} & 110 \\ 5039 & 10^{\circ} 35^{\prime} & 13^{\circ} 23.3^{\prime} & 88 \\ 5040 & 6^{\circ} 58^{\prime} & 12^{\circ} 37^{\prime} .1^{\prime} & 17 \\ 5043 & 7^{\circ} 20.8^{\prime} & 12^{\circ} 36.6^{\prime} & 26 \\ 5045 & 7^{\circ} 36^{\prime} & 12^{\circ} 33.7^{\prime} & 168 \\ 5046 & 7^{\circ} 46.6^{\prime} & 12^{\circ} 46.2^{\prime} & 99 \\ 5047 & 7^{\circ} 50^{\prime} & 13^{\circ} 00^{\prime} & 44 \\ 5049 & 8^{\circ} 37^{\prime} & 13^{\circ} 15^{\prime} & 40 \\ 5050 & 8^{\circ} 26^{\prime} & 13^{\circ} 13^{\prime} & 13^{\circ} 12^{\prime} \\ 5051 & 8^{\circ} 20^{\prime} & 46\end{array}$


SURFACE SAMPLES

Centre Océanologique de Bretagne

$\begin{array}{cccc}\text { Sample Number } & \text { Latitude }{ }^{\circ} \mathrm{S} & \text { Longitude }{ }^{\circ} \mathrm{E} & \text { Depth (m) } \\ \text { KW13 } & 18^{\circ} 25.5^{\prime} & 10^{\circ} 29^{\prime} & 3628 \\ \text { KW15 } & 14^{\circ} 21.8^{\prime} & 9^{\circ} 45.4^{\prime} & 3960 \\ \text { KR15 } & 12^{\circ} 12^{\prime} & 12^{\circ} 53^{\prime} & 1453 \\ \text { KW17 } & 12^{\circ} 02.8^{\prime} & 12^{\circ} 20.3^{\prime} & 2081 \\ \text { KR19 } & 12^{\circ} 19.7^{\prime} & 11^{\circ} 01.4^{\prime} & 3435 \\ \text { KW20 } & 10^{\circ} 37.5^{\prime} & 13^{\circ} 26.2^{\prime} & 92 \\ \text { KR20 } & 10^{\circ} 18.7^{\prime} & 11^{\circ} 44.7^{\prime} & 1866 \\ \text { KR21 } & 6^{\circ} 38.4^{\prime} & 8^{\circ} 10.1^{\prime} & 3961 \\ \text { KR22 } & 3^{\circ} 47^{\prime} & 9^{\circ} 17.5^{\prime} & 2299 \\ \text { KR23 } & 2^{\circ} 36.9^{\prime} & 8^{\circ} 20.9^{\prime} & 2494\end{array}$


Woods Hole Oceanographic Institution

\begin{tabular}{|c|c|c|c|c|}
\hline ore Number & Latitude ${ }^{\circ} \mathrm{S}$ & Longitude ${ }^{\circ} \mathrm{E}$ & Depth (m) & Core Length $(\mathrm{cm})$ \\
\hline CH99-38 & $8^{\circ} 35.9^{\prime}$ & $4^{\circ} 24.9^{\prime}$ & 5373 & 1187 \\
\hline Сн99-39 & $8^{\circ} 42.7^{\prime}$ & $6^{\circ} 30^{\prime}$ & 4938 & 1124 \\
\hline CH99-40 & $8^{\circ} 41^{\prime}$ & $8^{\circ} 31^{\prime}$ & 4515 & 1160 \\
\hline \multirow[t]{2}{*}{ CH99-41 } & $8^{\circ} 40.4^{\prime}$ & $10^{\circ} 26.7^{\prime}$ & 3855 & 1142 \\
\hline & \multicolumn{3}{|c|}{ Lamont-Doherty Geologica1 Observatory } & \\
\hline $\mathrm{V} 12-70$ & $6^{\circ} 28.6^{\prime}$ & $11^{\circ} 26.5^{\prime}$ & 450 & 610 \\
\hline $\mathrm{V} 12-71$ & $5^{\circ} 38^{\prime}$ & $10^{\circ} 41.1^{\prime}$ & 2255 & 1072 \\
\hline $\mathrm{V} 12-72$ & $5^{\circ} 37.6^{\prime}$ & $10^{\circ} 39.6^{\prime}$ & 2107 & 490 \\
\hline V12-73 & $5^{\circ} 54^{\prime}$ & $9^{\circ} 53.1^{\prime}$ & 3054 & 929 \\
\hline V12-74 & $6^{\circ} 00^{\prime}$ & $9^{\circ} 19.9^{\prime}$ & 3451 & 910 \\
\hline V12-75 & $6^{\circ} 18.7^{\prime}$ & $8^{\circ} 19.2^{\prime}$ & 4021 & 683 \\
\hline V12-76 & $5^{\circ} 42.9^{\prime}$ & $8^{\circ} 29.8^{\prime}$ & 4006 & 330 \\
\hline$V 19-260$ & $19^{\circ} 20^{\prime}$ & $9^{\circ} 37^{\prime}$ & 3585 & 1064 \\
\hline V19-261 & $18^{\circ} 59^{\prime}$ & $9^{\circ} 12^{\prime}$ & 4662 & 996 \\
\hline$V 19-262$ & $18^{\circ} 20^{\prime}$ & $8^{\circ} 23^{\prime}$ & 4918 & 1116 \\
\hline$V 19-263$ & $16^{\circ} 55^{\prime}$ & $6^{\circ} 36^{\prime}$ & 5278 & 31 \\
\hline$V 19-264$ & $16^{\circ} 10^{\prime}$ & $5^{\circ} 38^{\prime}$ & 5407 & 98 \\
\hline$V 19-265$ & $15^{\circ} 14^{\prime}$ & $4^{\circ} 30^{\prime}$ & 5512 & 260 \\
\hline V19-278 & $7^{\circ} 04^{\prime}$ & $5^{\circ} 34^{\prime}$ & 4967 & 996 \\
\hline$V 19-280$ & $4^{\circ} 56^{\prime}$ & $5^{\circ} 00^{\prime}$ & 4914 & 1594 \\
\hline $\mathrm{V} 19-281$ & $3^{\circ} 19^{\prime}$ & $4^{\circ} 39^{\prime}$ & 4566 & 1787 \\
\hline$V 19-282$ & $2^{\circ} 45^{\prime}$ & $4^{\circ} 35^{\prime}$ & 4356 & 2140 \\
\hline
\end{tabular}


CORES

Centre Océanologique de Bretagne

\begin{tabular}{|c|c|c|c|c|}
\hline Core Number & Latitude ${ }^{\circ} \mathbf{S}$ & Longitude ${ }^{\circ} \mathrm{E}$ & Depth (m) & Core Length $(\mathrm{cm})$ \\
\hline KW15 & $14^{\circ} 21.8^{\prime}$ & $9^{\circ} 45.5^{\prime}$ & 3960 & 859 \\
\hline KWI6 & $12^{\circ} 11.5^{\prime}$ & $12^{\circ} 51.0^{\prime}$ & 1453 & 825 \\
\hline KW17 & $12^{\circ} 02.8^{\prime}$ & $12^{\circ} 20.3^{\prime}$ & 2081 & 853 \\
\hline $\mathrm{KW} 18$ & $12^{\circ} 12.1^{\prime}$ & $11^{\circ} 50^{\prime}$ & 2606 & 585 \\
\hline KW19 & $12^{\circ} 19.1^{\prime}$ & $11^{\circ} 02.6^{\prime}$ & 3418 & 1698 \\
\hline KW20 & $10^{\circ} 37.5^{\prime}$ & $13^{\circ} 26.2^{\prime}$ & 92 & 840 \\
\hline $\mathrm{KW} 21$ & $10^{\circ} 18.7^{\prime}$ & $11^{\circ} 44.7^{\prime}$ & 1875 & 715 \\
\hline
\end{tabular}


ADDITIONAL CORE AND SAMPIE DESCRIPTIONS USED

Lamont-Doherty Geological Observatory

\begin{tabular}{|c|c|c|c|c|}
\hline Core Number & Latitude ${ }^{\circ} \mathrm{S}$ & Longitude ${ }^{\circ} \mathrm{E}$ & Depth (m) & Core Length $(\mathrm{cm})$ \\
\hline V19-259 & $19^{\circ} 52^{\prime}$ & $11^{\circ} 02^{\prime}$ & 1170 & 970 \\
\hline V19-277 & $7^{\circ} 10^{\prime}$ & $5^{\circ} 08^{\prime}$ & 5092 & 1344 \\
\hline V19-137 & $6^{\circ} 31^{\prime}$ & $10^{\circ} 04^{\prime}$ & 3486 & 1015 \\
\hline$. V 19-139$ & $4^{\circ} 34^{\prime}$ & $8^{\circ} 95^{\prime}$ & 3590 & 1610 \\
\hline$V 19-141$ & $2^{\circ} 38^{\prime}$ & $6^{\circ} 29^{\prime}$ & 3993 & 1520 \\
\hline V19-142 & $2^{\circ} 05^{\prime}$ & $6^{\circ} 23^{\prime}$ & 1017 & 1040 \\
\hline V19-266 & $14^{\circ} 36^{\prime}$ & $3^{\circ} 40^{\prime}$ & 5543 & 480 \\
\hline$V 19-267$ & $13^{\circ} 23^{\prime}$ & $2^{\circ} 13^{\prime}$ & 5585 & 545 \\
\hline$V 19-276$ & $8^{\circ} 58^{\prime}$ & $2^{\circ} 52^{\prime}$ & & \\
\hline СН99-42 & $8^{\circ} 40.5^{\prime}$ & $11^{\circ} 49.5^{\prime}$ & 1945 & 606 \\
\hline CH99-46 & $8^{\circ} 50.5^{\prime}$ & $11^{\circ} 49.2^{\prime}$ & 2195 & 855 \\
\hline CH99-48 & $11^{\circ} 05^{\prime}$ & $10^{\circ} 44^{\prime}$ & 3961 & 1160 \\
\hline CH99-5I & $19^{\circ} 57^{\prime}$ & $9^{\circ} 21.2^{\prime}$ & 2324 & 948 \\
\hline CH99-49 & $19^{\circ} 00^{\prime}$ & $10^{\circ} 04^{\prime}$ & 4146 & 1009 \\
\hline \multicolumn{5}{|c|}{ "Meteor" Expedition } \\
\hline 180 & $21^{\circ} 45^{\prime}$ & $4^{\circ} 30^{\prime}$ & 4730 & -- \\
\hline 183 & $21^{\circ} 53^{\prime}$ & $12^{\circ} 27^{\prime}$ & 989 & - \\
\hline 184 & $22^{\circ} 00^{\prime}$ & $11^{\circ} 07.2^{\prime}$ & 3055 & 29 \\
\hline $184 a$ & $17^{\circ} 56.2^{\prime}$ & $11^{\circ} 21.9^{\prime}$ & 408 & -- \\
\hline $184 b$ & $17^{\circ} 13.1^{\prime}$ & $11^{\circ} 43.4^{\prime}$ & 42 & - \\
\hline $184 \mathrm{c}$ & $17^{\circ} 11^{\prime}$ & $11^{\circ} 39.6^{\prime}$ & 77 & -- \\
\hline
\end{tabular}


ADDITIONAL CORE AND SAMPLE DESCRIPTION USED

"Meteor" Expedition

\begin{tabular}{|c|c|c|c|c|}
\hline Core Number & Latitude ${ }^{\circ} \mathrm{S}$ & Longitude ${ }^{\circ} \mathrm{E}$ & Depth (m) & Core Length $(\mathrm{cm})$ \\
\hline $184 d$ & \multicolumn{2}{|c|}{ LUANDA HARBOR } & 21 & \\
\hline $184 \mathrm{e}$ & $8^{\circ} 49.3^{\prime}$ & $12^{\circ} 56.9^{\prime}$ & 217 & -- \\
\hline 185 & $8^{\circ} 52.2^{\prime}$ & $12^{\circ} 38.3^{\prime}$ & 993 & 35 \\
\hline 186 & $8^{\circ} 58.8^{\prime}$ & $10^{\circ} 53.4^{\prime}$ & 3186 & 43 \\
\hline 187 & $8^{\circ} 45.4^{\prime}$ & $13^{\circ} 00.5^{\prime}$ & 192 & -- \\
\hline 188 & $8^{\circ} 58^{\prime}$ & $8^{\circ} 57.7^{\prime}$ & 4482 & 43 \\
\hline 189 & $9^{\circ} 00^{\prime}$ & $6^{\circ} 00^{\prime}$ & 5066 & 86 \\
\hline 140 & $18^{\circ} 44.9^{\prime}$ & $10^{\circ} 36.5^{\prime}$ & 2961 & 30 \\
\hline 141 & $16^{\circ} 35.1^{\prime}$ & $11^{\circ} 44.5^{\prime}$ & 28 & -- \\
\hline 142 & $16^{\circ} 22.5^{\prime}$ & $11^{\circ} 23.2^{\prime}$ & 979 & 31 \\
\hline 143 & $16^{\circ} 20^{\prime} .2^{\prime}$ & $10^{\circ} 54.9^{\prime}$ & 2925 & 50 \\
\hline 144 & $16^{\circ} 03.5^{\prime}$ & $9^{\circ} 28.9^{\prime}$ & 4414 & 36.5 \\
\hline 145 & $15^{\circ} 16.5^{\prime}$ & $6^{\circ} 32.6^{\prime}$ & 5238 & 43 \\
\hline 146 & $15^{\circ} 08^{\prime}$ & $2^{\circ} 59^{\prime}$ & 5618 & 66 \\
\hline
\end{tabular}


APPENDIX II

Analytica1 Results 


\section{SURFACE SAMPLES}

\section{Organic Carbon (\%)}

$\begin{array}{lccc}\text { Samp1e } & \text { \% Organic Carbon } & \text { Sample } & \text { \% Organic Carbon } \\ \text { KW13 } & 1.37 & \text { V12-71 } & 2.57 \\ \text { KW15 } & 1.28 & \text { V12-72 } & 1.73 \\ \text { KW16 } & 1.25 & \text { V12-75 } & 1.16 \\ \text { KW17 } & 1.00 & & 1.15 \\ \text { KW19 } & 0.92 & \text { V19-260 } & 0.83 \\ \text { KW20 } & 1.03 & \text { V19-261 } & 2.28 \\ \text { KW21 } & 1.56 & \text { V19-262 } & 0.34 \\ \text { KW22 } & 2.74 & \text { V19-263 } & 0.25 \\ \text { KW23 } & 1.52 & \text { V19-264 } & 2.15 \\ \text { KW24 } & 1.99 & \text { V19-265 } & 1.01 \\ \text { CH99-39 } & 1.89 & \text { V19-278 } & 1.26 \\ \text { CH99-40 } & 1.22 & \text { V19-280 } & 0.26 \\ \text { CH99-41 } & 1.26 & \text { V19-281 } & 0.47\end{array}$




\section{CORES}

Organic Carbon (\%)

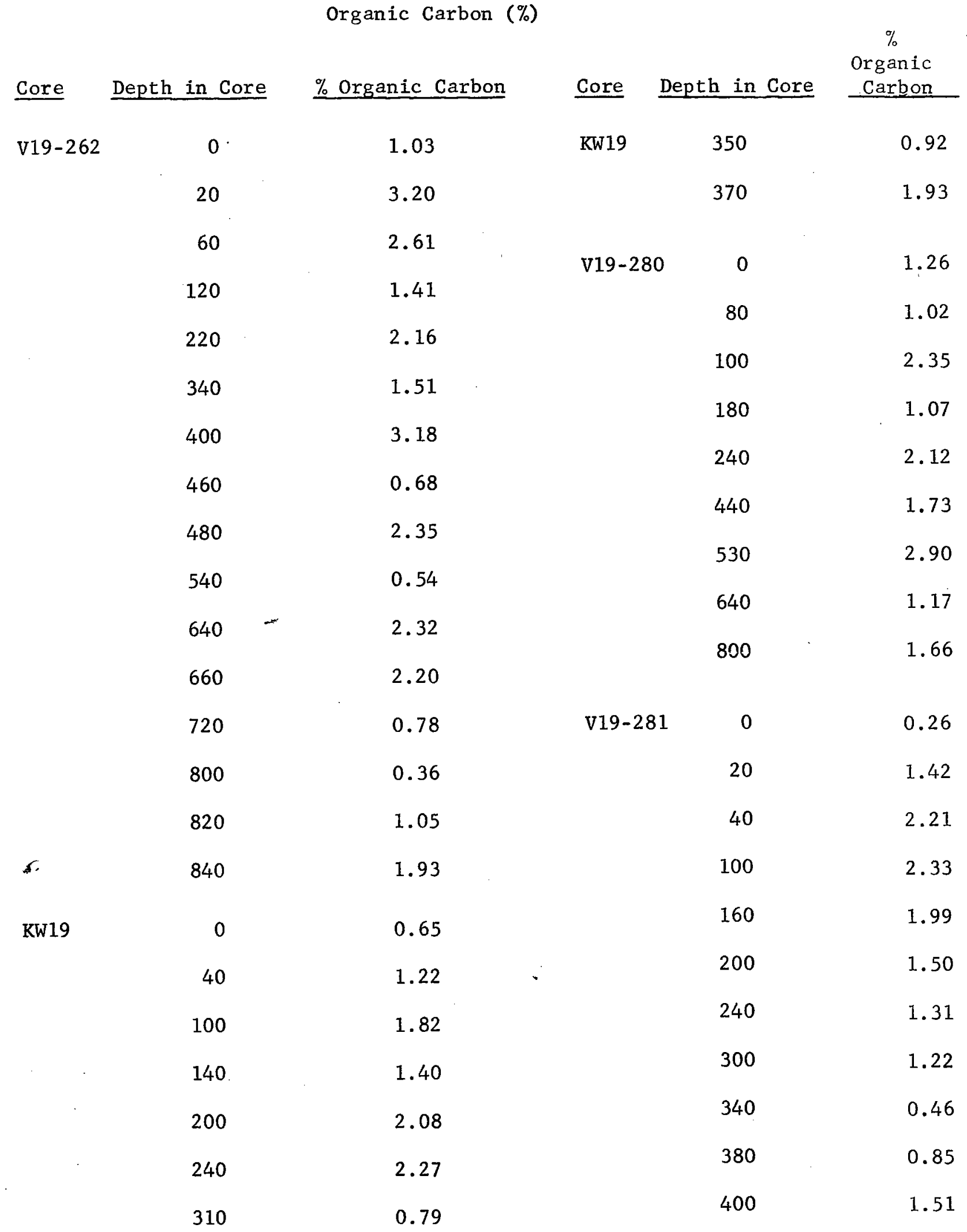




\section{CORES}

Organic Carbon (\%)

$\begin{array}{cc}\text { Core } & \text { Depth in Core } \\ \text { V19-281 } & \text { Organic Carbon } \\ 420 & 1.72 \\ 460 & 1.56 \\ 580 & 0.51 \\ 600 & 0.80 \\ 620 & 1.89 \\ 660 & 1.36 \\ 700 & 1.23 \\ 720 & 1.72 \\ 780 & 1.63\end{array}$


SURFACE SAMPLES

C1ay Minera1s (\%)

Crysta11inity

$(\mathrm{v} / \mathrm{p})$

Sample Montmorillonite I1lite Kaolinite Chlorite Montmorillonite

V19-260

37.5

48.4

7.1

7.0

0.37

V19-261

42.2

44.6

10.0

32.7

8.2

58.7

6.0

42.2

8.0

24.3

27.7

17.1

34.2

0.0

34.5

15.7

48.9

20.2

42.8

22.3

13.5

35.4

15.6

55.6

25.0

57.1

62.8

26.4

44.6

43.4

47.0

50.3
$19.5 \quad 24.0$

15.0

15.6

15.3

56.7

34.2

30.2

29.8

23.7

60.0

27.3

21.9

15.0

20.0

26.4

23.2

26.0
57.7

5.0

0.32

5.0

0.11

2.0

0.18

5.0

0.22

5.0

$-0.22$

0.0

0.32

0.0

0.00

0.0

0.08

0.0

0.00

0.0

0.14

0.0

0.19

0.0

0.00

49.0

5.0

0.43

0.0

0.16

0.0

0.50

0.0

0.74

5.0

0.29

5.0

0.59

KW16

0.0

0.55

KW17

0.0

0.64

KW18

0.0

0.74 
SURFACE SAMPLES

Clay Minerals

Crystallinity

$(\mathrm{v} / \mathrm{p})$

Sample Montmorillonite Illite Kaolinite Chlorite Montmorillonite

KW19

42.5

42.5

13.0

5.0

0.45

KW20

36.2

KW21

KW22

KW2 3

KW24

BCF94

BCF96

BCF99

BCF103

BCF 105

C506

C605

C783

C800

C585

C615

5019

5022

5025

5030

5034

5037
46.6

31.2

51.0

45.0

12.3

18.6

34.4

14.3

31.4

6.0

4.7

19.0

7.6

2.6

6.8

32.2

33.6

$38: 8$

42.6

35.5

43.6
40.6

26.6

25.5

9.4

15.1

58.9

61.6

43.0

63.4

42.8

24.9

24.4

22.0

33.7

28.2

25.8

46.8

48.9

43.4

35.0

27.4

30.6
23.2

26.8

43.3

39.6

39.9

20.8

19.8

21.0

20.0

14.0

69.1

70.9

59.0

58.7

69.2

67.4

21.0

17.5

17.8

22.4

37.1

26.8
0.0

0.44

0.0

0.44

0.0

0.22

0.0

0.67

0.0

0.51

8.0

0.26

0.0

0.00

5.0

0.36

5.0

0.34

5.0

0.27

0.0

$-0.09$

0.0

0.00

0.0

0.29

0.0

0.15

0.0

$-0.20$

0.0

0.00

0.0

0.42

0.0

0.42

0.0

0.44

0.0

0.45

0.0

0.62

0.0

0.54 


\section{SURFACE SAMPLES}

\section{C1ay Minera1s}

Crysta1linity $(\mathrm{v} / \mathrm{p})$

\begin{tabular}{|c|c|c|c|c|c|}
\hline Samp le & Montmorillonite & Illite & Kaolinite & Chlorite & Montmorillonite \\
\hline 5039 & 39.6 & 28.2 & 32.2 & 0.0 & 0.73 \\
\hline 5040 & 11.6 & 33.1 & 55.3 & 0.0 & 0.14 \\
\hline 5043 & 13.0 & 24.2 & 62.8 & 0.0 & 0.29 \\
\hline 5045 & 18.6 & 28.9 & 52.5 & 0.0 & 0.26 \\
\hline 5046 & 13.0 & 31.1 & 55.9 & 0.0 & 0.33 \\
\hline 5047 & 7.3 & 41.4 & 51.3 & 0.0 & 0.28 \\
\hline 5049 & 10.2 & 45.2 & 44.6 & 0.0 & 0.45 \\
\hline 5050 & 13.8 & 36.5 & 49.7 & 0.0 & 0.50 \\
\hline 5051 & 7.7 & 42.1 & 50.2 & 0.0 & 0.65 \\
\hline
\end{tabular}




\section{PISTON CORES}

Clay Minerals

180

Core V19-261

Sample Depth Montmorillonite Illite Kaolinite Chlorite (v/p)

$\begin{array}{rrrrrr}80 & 25.1 & 59.1 & 10.0 & 5.8 & 0.60 \\ 140 & 22.6 & 59.0 & 18.4 & 0.0 & 0.49 \\ 180 & 34.7 & 46.7 & 14.0 & 4.6 & 0.28 \\ 280 & 31.0 & 58.6 & 8.0 & 2.4 & 0.22 \\ 340 & 30.5 & 52.8 & 12.7 & 5.0 & 0.22 \\ 540 & 42.9 & 38.1 & 15.0 & 4.0 & 0.49 \\ 600 & 31.6 & 56.8 & 8.6 & 5.0 & 0.27 \\ 740 & 24.5 & 60.4 & 10.1 & 5.0 & 0.25 \\ 800 & 23.2 & 68.1 & 5.7 & 3.0 & 0.39\end{array}$

Core V19-262

$\begin{array}{llllll}360 & 31.8 & 57.9 & 6.7 & 3.6 & 0.44 \\ 540 & 40.5 & 45.9 & 8.7 & 4.9 & 0.50 \\ 580 & 17.6 & 74.0 & 5.4 & 3.0 & 0.46 \\ 700 & 19.7 & 69.7 & 8.4 & 3.2 & 0.29 \\ 800 & 33.6 & 41.7 & 16.0 & 8.7 & 0.46\end{array}$

Core KW15

40

80

160

220
53.6

57.1

57.6

57.8
24.4

24.5

25.2

24.0
22.0

18.4

17.3

18.2
0.0

0.0

0.0

0.0
0.69

0.59

0.54

0.42 


\section{PISTON CORES}

C1ay Minera1s

Core KW15

Sample Depth Montmorillonite Illite Kaolinite Chlorite (v/p)

$\begin{array}{llllll}260 & 54.6 & 25.6 & 19.8 & 0.0 & 0.44 \\ 380 & 54.6 & 23.4 & 22.0 & 0.0 & 0.55 \\ 460 & 65.4 & 21.3 & 13.3 & 0.0 & 0.44 \\ 520 & 21.4 & 16.9 & 0.0 & 0.50 \\ 560 & 61.7 & 20.5 & 14.8 & 0.0 & 0.55 \\ 640 & 64.6 & 29.2 & 18.4 & 0.0 & 0.44 \\ 700 & 52.3 & 28.2 & 19.4 & 0.0 & 0.45 \\ 780 & 52.4 & 26.8 & 20.0 & 0.0 & 0.44 \\ 816 & 53.2 & 24.6 & 15.2 & 0.0 & 0.51\end{array}$

\section{Core KW19}

$\begin{array}{rlllll}40 & 51.5 & 24.5 & 24.0 & 0.0 & 0.62 \\ 80 & 60.0 & 20.2 & 19.8 & 0.0 & 0.58 \\ 120 & 56.9 & 20.4 & 22.8 & 0.0 & 0.62 \\ 200 & 60.0 & 18.5 & 21.5 & 0.0 & 0.62 \\ 260 & 63.2 & 16.0 & 20.8 & 0.0 & 0.51 \\ 300 & 62.6 & 15.6 & 21.8 & 0.0 & 0.56 \\ 330 & 65.9 & 17.1 & 17.0 & 0.0 & 0.43 \\ 390 & 61.6 & 16.6 & 21.8 & 0.0 & 0.57\end{array}$

\section{Core CH99-41}

$\begin{array}{rrrrrr}40 & 57.0 & 15.0 & 28.0 & 0.0 & 0.72 \\ 120 & 57.1 & 15.6 & 27.3 & 0.0 & 0.64 \\ 260 & 63.6 & 14.6 & 21.8 & 0.0 & 0.64\end{array}$




\section{PISTON CORES}

Clay Minerals

Core CH99-41

Sample Depth

300

480

500

600

640

700

720

780

900

Core V19-281

60

100

140

200

280

300

380

420

600

640

680

740

\section{Montmorillonite Illite}

58.2

60.0

56.9

54.1

51.9

60.2

55.5

54.6

50.4

15.2

14.6

17.3

16.4

17.2

11.4

14.2

14.1

18.5

31.1

26.8

25.4

25.8

29.5

30.9

28.4

30.3

31.3

0.0

0.0

0.0

0.75 
SURFACE SEDIMENTS

Calcium Carbonate and Texture

Congo Repub1ic

\begin{tabular}{crrrr} 
Samp le Number & \% $\mathrm{CaCO}_{3}$ & \% Sand & \% Silt & \% Clay \\
\hline 506 & 8.02 & 1.0 & 59.0 & 40.0 \\
513 & 6.00 & 6.0 & 50.0 & 44.0 \\
576 & 10.00 & 37.0 & 46.0 & 16.0 \\
585 & 6.15 & 32.0 & 52.0 & 16.0 \\
605 & 12.04 & 90.0 & 5.0 & 5.0 \\
615 & 17.18 & 72.0 & 17.0 & 11.0 \\
783 & 16.93 & 70.0 & 22.0 & 7.0 \\
791 & 11.00 & 39.0 & 52.0 & 9.0 \\
800 & 6.58 & 47.0 & 43.0 & 9.0
\end{tabular}

Bureau of Commercial Fisheries

$\begin{array}{rrrrr}92 & 0.00 & 97.8 & 00.8 & 1.4 \\ 93 & 61.00 & 96.1 & 2.4 & 1.5 \\ 94 & 4.00 & 97.7 & 6.5 & 1.8 \\ 96 & 10.3 & 95.6 & 2.7 & 1.7 \\ 97 & 1.0 & 98.9 & 0.1 & 1.0 \\ 99 & 21.4 & 84.1 & 13.2 & 2.7 \\ 101 & 0.0 & 98.4 & 0.2 & 1.4 \\ 102 & 5.3 & 87.4 & 10.5 & 2.1 \\ 103 & 3.7 & 56.4 & 37.5 & 6.1 \\ 104 & 39.9 & 90.8 & 8.5 & 0.7\end{array}$


SURFACE SEDTMENTS

Calcium Carbonate and Texture

184

Bureau of Commercial Fisheries

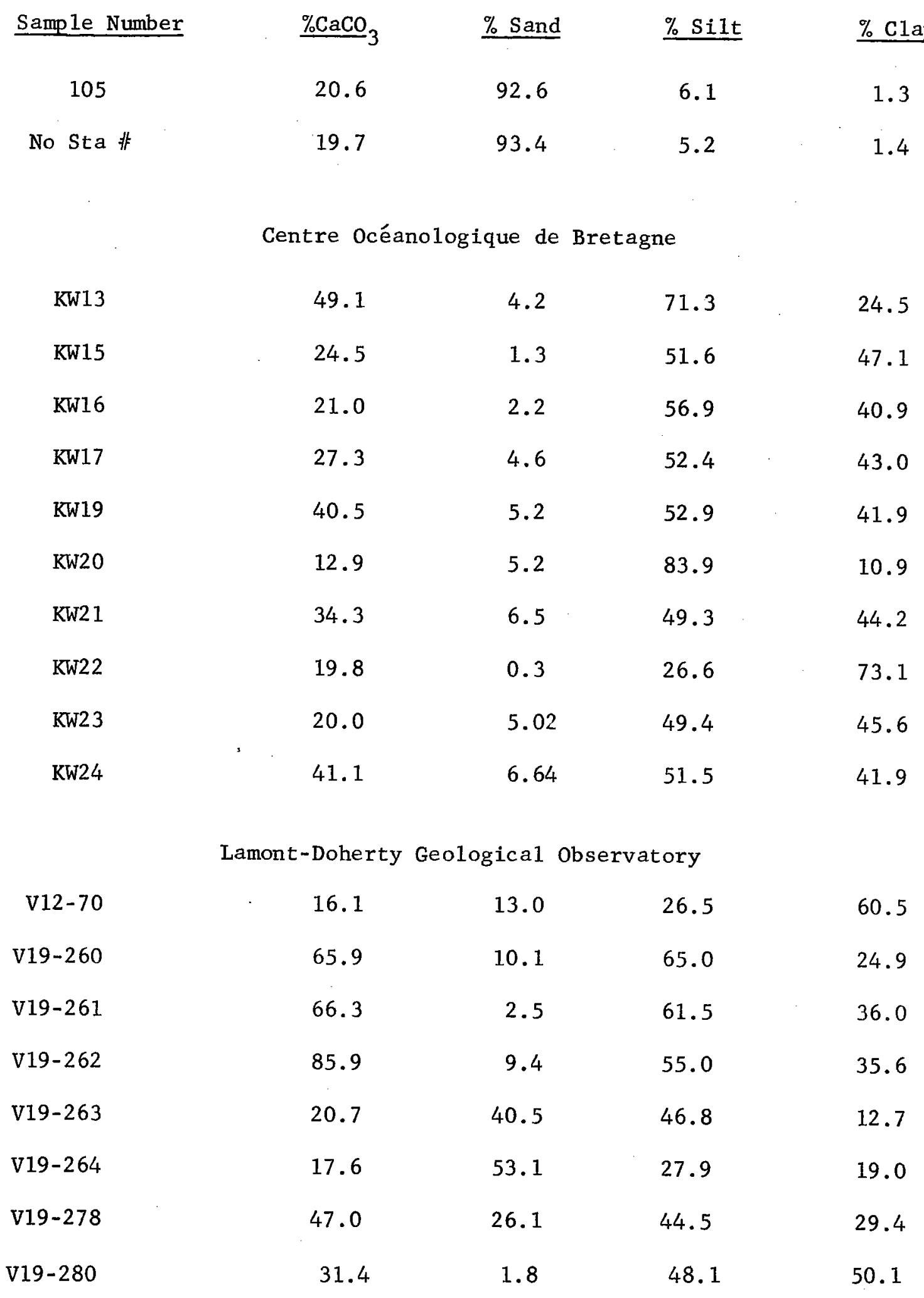




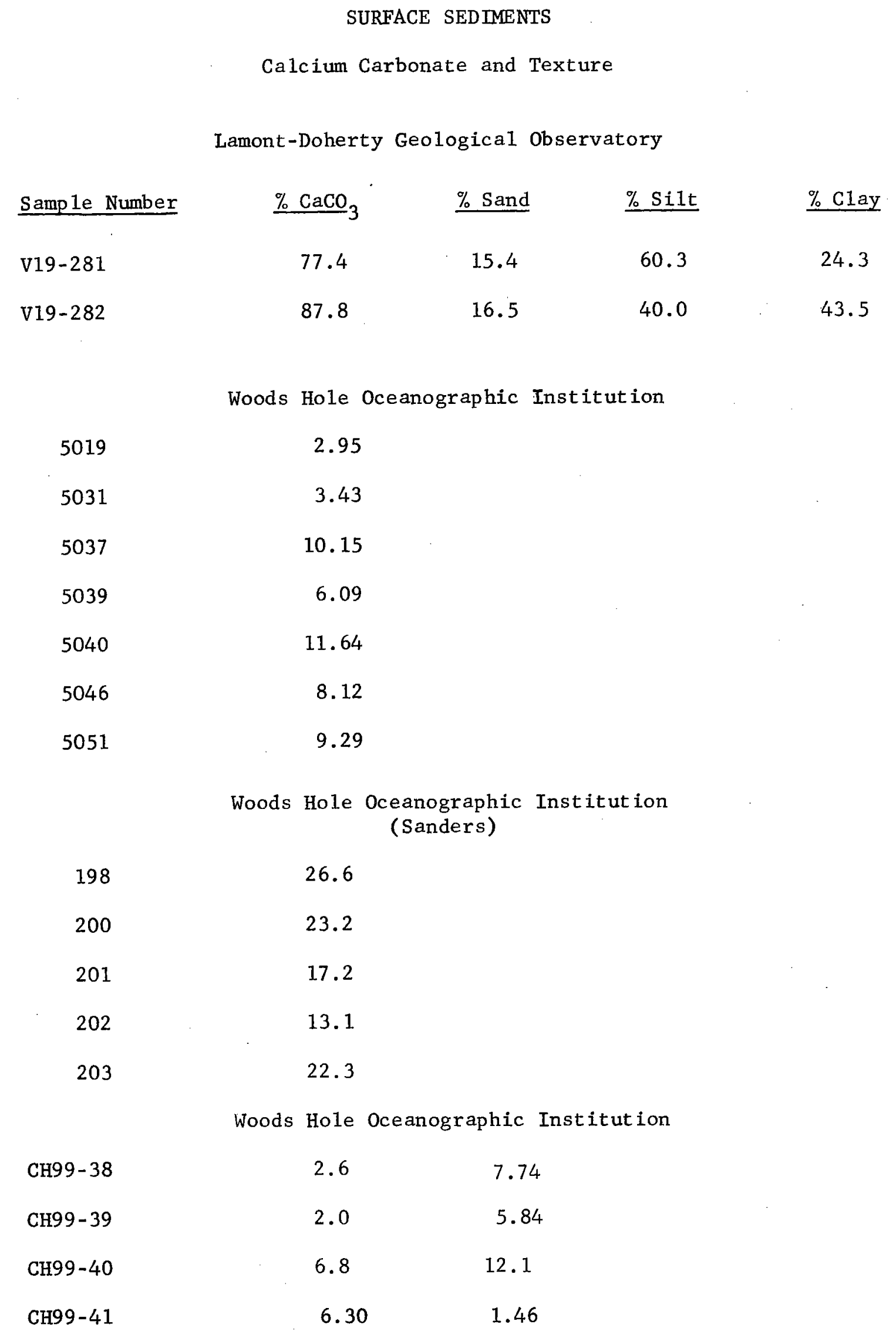


CORE KW 15

\begin{tabular}{|c|c|c|c|c|c|}
\hline Samp le & $\underline{\mathrm{CaCO}}_{3}$ & Sand & Samp 1e & $\mathrm{CaCO}_{3}$ & Sand \\
\hline 0 & 32.94 & 12.13 & 440 & 4.89 & 0.69 \\
\hline 18 & 38.50 & 19.33 & 460 & 6.17 & 1.76 \\
\hline 40 & 22.04 & 7.16 & 480 & 5.44 & 2.12 \\
\hline 58 & 10.10 & 10.63 & 500 & 25.56 & 3.33 \\
\hline 78 & 9.16 & 2.57 & 518 & 27.55 & 2.90 \\
\hline 100 & 16.21 & 3.42 & 540 & 26.24 & 5.79 \\
\hline 120 & 20.20 & 8.08 & 560 & 6.60 & 1.50 \\
\hline 133.5 & 9.59 & 52.49 & 580 & 27.21 & 3.30 \\
\hline 140 & 11.90 & 7.19 & 600 & 18.28 & 3.25 \\
\hline 160 & 8.96 & 1.54 & 620 & 8.84 & 2.21 \\
\hline 180 & 7.04 & 2.12 & 640 & 8.65 & 1.31 \\
\hline 205 & 21.29 & 5.81 & 660 & 5.28 & 1.51 \\
\hline 220 & 17.08 & 5.39 & 685 & 30.42 & 2.93 \\
\hline 240 & 20.48 & 4.91 & 700 & 9.20 & 2.16 \\
\hline 260 & 20.06 & 5.03 & 720 & 19.51 & 2.33 \\
\hline 280 & 3.49 & 3.42 & 740 & 20.24 & 2.13 \\
\hline 300 & 13.37 & 7.88 & 760 & 17.83 & 2.47 \\
\hline 320 & 38.35 & 22.61 & 780 & 41.19 & 3.09 \\
\hline 340 & 15.57 & 4.88 & 803 & 27.02 & 2.92 \\
\hline 360 & 6.19 & 2.84 & 816 & 3.51 & 0.74 \\
\hline 380 & 6.47 & 2.74 & 840 & 20.46 & 3.07 \\
\hline 398 & 5.38 & 2.14 & & & \\
\hline 410 & 25.64 & 12.75 & & & \\
\hline 420 & 4.39 & 3.70 & & & \\
\hline
\end{tabular}




\begin{tabular}{|c|c|c|}
\hline Samp 1e & $\underline{\mathrm{CaCO}}_{3}$ & Sand \\
\hline 0 & 23.31 & 19.84 \\
\hline 20 & 30.62 & 7.07 \\
\hline 40 & 19.77 & 4.68 \\
\hline 60 & 19.06 & 5.37 \\
\hline 80 & 14.23 & 0.77 \\
\hline 100 & 18.50 & 0.67 \\
\hline 120 & 18.16 & 0.94 \\
\hline 140 & 12.11 & 5.07 \\
\hline 160 & 15.63 & 2.57 \\
\hline 180 & 14.13 & 2.26 \\
\hline 200 & 10.78 & 5.95 \\
\hline 220 & 15.46 & 1.55 \\
\hline 240 & 10.53 & 0.88 \\
\hline 260 & 18.53 & 4.41 \\
\hline 280 & 15.78 & 5.11 \\
\hline 300 & 8.75 & 13.00 \\
\hline 310 & 24.79 & 11.25 \\
\hline 330 & 18.66 & 4.45 \\
\hline 350 & 20.45 & 3.98 \\
\hline 370 & 4.96 & 0.29 \\
\hline 390 & -- & 0.82 \\
\hline Bottom & 12.09 & 79.12 \\
\hline
\end{tabular}


CORE KW21

\begin{tabular}{|c|c|c|c|c|c|}
\hline Sample & $\underline{\mathrm{CaCO}}_{3}$ & Sand & Samp 1e & $\underline{\mathrm{CaCO}}_{3}$ & Sand \\
\hline 0 & 33.80 & 16.59 & 440 & 2.20 & 1.51 \\
\hline 10 & 23.05 & 13.19 & 460 & 6.12 & 1.13 \\
\hline 25 & 10.02 & 7.59 & 480 & 6.71 & 0.07 \\
\hline 40 & 7.95 & 3.49 & 498 & 6.50 & 2.10 \\
\hline 60 & 8.77 & 3.82 & 520 & 6.07 & 2.33 \\
\hline 80 & 10.96 & 3.86 & 540 & 5.76 & 1.15 \\
\hline 100 & 10.00 & 5.09 & 560 & 4.77 & 0.84 \\
\hline 120 & 5.34 & 5.53 & 580 & 4.46 & 0.95 \\
\hline 140 & 7.31 & 3.58 & 605 & 4.53 & 0.50 \\
\hline 160 & 9.29 & 1.94 & & & \\
\hline 180 & 8.46 & 2.39 & & & \\
\hline 200 & 8.54. & 2.15 & & & \\
\hline 220 & 8.84 & 1.31 & & & \\
\hline 240 & 9.00 & 1.18 & & & \\
\hline 260 & 3.47 & 1.45 & & & \\
\hline 280 & 8.96 & 1.83 & & & \\
\hline 300 & 5.66 & 0.64 & & & \\
\hline 320 & 6.75 & 0.47 & & & \\
\hline 340 & 7.31 & 1.03 & & & \\
\hline 360 & 7.03 & 1.08 & & & \\
\hline 380 & 4.50 & 3.22 & & & \\
\hline 400 & 6.83 & 0.62 & & & \\
\hline 410 & 5.18 & 2.72 & & & \\
\hline 420 & 6.90 & 1.01 & & & \\
\hline
\end{tabular}




\begin{tabular}{|c|c|c|c|c|c|}
\hline Sample & $\underline{\mathrm{CaCO}}_{3}$ & Sand & Samp 1e & $\underline{\mathrm{CaCQ}}_{3}$ & Sand \\
\hline 20 & 20.1 & 2.52 & 500 & 19.3 & 1.14 \\
\hline 60 & 26.3 & 3.16 & 520 & 24.7 & 1.78 \\
\hline 80 & 22.5 & 0.56 & 540 & 19.8 & 0.82 \\
\hline 100 & 22.7 & 0.73 & 560 & 20.0 & 0.03 \\
\hline 120 & 13.6 & 0.28 & 580 & 17.7 & 0.62 \\
\hline 140 & 20.6 & 0.78 & 600 & 21.9 & 1.01 \\
\hline 160 & 24.7 & 1.36 & & & \\
\hline 180 & 20.0 & 0.52 & & & \\
\hline 200 & 20.1 & 0.63 & & & \\
\hline 220 & 22.2 & 0.96 & & & \\
\hline 240 & 22.0 & 1.38 & & & \\
\hline 260 & 24.1 & 1.62 & & & \\
\hline 280 & 18.7 & 0.36 & & & \\
\hline 300 & 26.2 & 1.42 & & & \\
\hline 320 & 25.0 & 1.23 & & & \\
\hline 340 & 23.5 & 1.07 & & & \\
\hline 360 & 22.0 & 0.40 & & & \\
\hline 380 & 19.7 & 0.52 & & & \\
\hline 400 & 18.5 & 0.78 & & & \\
\hline 420 & 21.3 & 0.87 & & & \\
\hline 440 & 20.3 & 1.21 & & & \\
\hline 460 & 17.4 & 0.09 & & & \\
\hline 480 & 17.9 & 1.11 & & & \\
\hline
\end{tabular}


CORE V12-72

\begin{tabular}{|c|c|c|}
\hline Samp 1a. & $\mathrm{CaCO}_{3}$ & Sand \\
\hline 20 & 8.95 & 1.72 \\
\hline 40 & 6.42 & 0.30 \\
\hline 60 & 5.44 & 2.77 \\
\hline 80 & 8.36 & 0.00 \\
\hline 100 & 8.62 & 0.10 \\
\hline 120 & 8.87 & 0.12 \\
\hline 140 & 6.64 & 0.13 \\
\hline 160 & 7.64 & 0.19 \\
\hline 180 & 10.69 & 0.12 \\
\hline 200 & 11.79 & 0.30 \\
\hline 220 & 13.02 & 0.54 \\
\hline 240 & 6.49 & 1.31 \\
\hline 260 & 9.59 & 0.57 \\
\hline 280 & 13.11 & 0.68 \\
\hline 300 & 11.87 & 0.89 \\
\hline 320 & 6.77 & 0.63 \\
\hline 340 & 10.50 & 0.48 \\
\hline 360 & 7.08 & 0.23 \\
\hline 380 & 4.22 & 0.66 \\
\hline 400 & 4.47 & 1.10 \\
\hline 420 & 9.27 & 0.00 \\
\hline 440 & 1.50 & 0.51 \\
\hline 460 & 1.98 & 0.02 \\
\hline 480 & 2.94 & 0.04 \\
\hline 490 & 6.36 & 0.38 \\
\hline
\end{tabular}


CORE V12-75

\begin{tabular}{|c|c|c|c|c|c|}
\hline Samp le & $\underline{\mathrm{CaCO}}_{3}$ & $\underline{\text { San } \mathrm{d}}$ & Sample & $\underline{\mathrm{CaCO}}_{3}$ & Sand \\
\hline 40 & 10.0 & 0.20 & 500 & 6.3 & - \\
\hline 60 & 8.9 & 0.13 & 520 & -- & 0.11 \\
\hline 80 & 4.7 & 0.17 & 540 & 0.9 & 0.30 \\
\hline 100 & 9.2 & 0.28 & 560 & 7.5 & 0.74 \\
\hline 120 & 6.5 & 0.06 & 580 & 4.5 & 0.17 \\
\hline 140 & 7.5 & 0.05 & 600 & 13.8 & 0.62 \\
\hline 160 & 5.9 & 0.04 & 620 & 1.6 & 0.38 \\
\hline 180 & 5.3 & 0.12 & 640 & -- & 0.04 \\
\hline 200 & 8.0 & 1.01 & 660 & 0.7 & 0.08 \\
\hline 220 & 6.2 & 0.18 & 680 & 5.9 & 0.35 \\
\hline 240 & 6.7 & 0.16 & & & \\
\hline 260 & 4.2 & 0.32 & & & \\
\hline 280 & 5.9 & 0.25 & & & \\
\hline 300 & 9.6 & 1.51 & & & \\
\hline 320 & 6.3 & 0.08 & & & \\
\hline 340 & 4.8 & 0.05 & & & \\
\hline 360 & 1.3 & 0.09 & & & \\
\hline 380 & 7. 1. & 0.04 & & & \\
\hline 400 & 10.1 & 0.27 & & & \\
\hline 420 & 4.9 & 0.10 & & & \\
\hline 440 & 3.9 & 0.39 & & & \\
\hline 460 & 4.9 & 0.08 & & & \\
\hline 480 & 5.8 & 0.05 & & & \\
\hline
\end{tabular}


CORE V19-260

\begin{tabular}{|c|c|c|c|c|c|}
\hline Sample & $\mathrm{CaCO}_{3}$ & Sand & $\underline{\text { Samp 1e }}$ & $\underline{\mathrm{CaCO}}_{3}$ & Sand \\
\hline 20 & 69.6 & 5.63 & 480 & 42.6 & 3.89 \\
\hline 40 & 70.2 & 6.68 & 500 & 52.7 & 3.21 \\
\hline 60 & 67.4 & 4.37 & 520 & 50.0 & 1.86 \\
\hline 80 & 66.6 & 4.01 & 540 & 47.4 & 1.32 \\
\hline 100 & 63.3 & 2.73 & 560 & 57.8 & 2.45 \\
\hline 120 & 69.0 & 2.56 & 580 & 49.2 & 2.52 \\
\hline 140 & 59.1 & 3.01 & 600 & 27.5 & 0.67 \\
\hline 160 & 55.0 & 2.76 & 620 & 43.6 & 0.89 \\
\hline 180 & 51.1 & 3.02 & 640 & 54.9 & 1.74 \\
\hline 200 & 46.9 & 4.21 & 660 & 52.9 & 2.03 \\
\hline 220 & 43.3 & 2.63 & 680 & 53.5 & 1.83 \\
\hline 240 & 45.5 & 2.18 & 700 & 46.2 & 0.97 \\
\hline 260 & 35.4 & 1.76 & 720 & 56.1 & 2.33 \\
\hline 280 & 36.7 & 2.63 & 740 & 49.2 & 1.96 \\
\hline 300 & 38.3 & 2.81 & 760 & 45.7 & 2.02 \\
\hline 320 & 40.3 & 4.21 & 780 & 35.0 & 1.36 \\
\hline 340 & 37.5 & 0.88 & 800 & 51.6 & 3.16 \\
\hline 360 & 46.8 & 1.32 & 820 & 55.9 & 3.42 \\
\hline 380 & 45.8 & 2.01 & 840 & 56.8 & 3.89 \\
\hline 400 & 54.0 & 4.22 & 860 & 52.9 & 3.22 \\
\hline 420 & 39.6 & 3.63 & 880 & 57.0 & 2.87 \\
\hline 440 & 39.3 & 3.43 & 900 & 51.5 & 3.12 \\
\hline \multirow[t]{3}{*}{460} & 45.7 & 2.18 & 920 & 47.5 & 0.86 \\
\hline & & & 940 & 40.1 & 1.03 \\
\hline & & & 960 & 38.4 & 0.92 \\
\hline
\end{tabular}


CORE V19-261

\begin{tabular}{|c|c|c|c|c|c|}
\hline Sample & $\underline{\mathrm{CaCO}}_{3}$ & Sand & Samp le & $\underline{\mathrm{CaCO}}_{3}$ & Sand \\
\hline 20 & 24.8 & 1.04 & 520 & 45.9 & 2.79 \\
\hline 40 & 24.1 & 1.03 & 540 & 60.5 & 16.69 \\
\hline 60 & 19.5 & 2.03 & 560 & 50.2 & 4.20 \\
\hline 80 & 24.8 & 1.91 & 580 & 17.2 & 0.81 \\
\hline 100 & 31.8 & 1.12 & 600 & 25.6 & 3.88 \\
\hline 120 & 46.0 & 1.38 & 620 & 30.2 & 2.17 \\
\hline 140 & 50.2 & 3.74 & 640 & 15.6 & 1.54 \\
\hline 160 & 60.5 & 5.28 & 660 & 18.0 & 1.74 \\
\hline 180 & 51.5 & 2.74 & 680 & 20.3 & 2.02 \\
\hline 200 & 25.7 & 0.22 & 700 & 53.2 & 4.20 \\
\hline 220 & 25.2 & 0.38 & 720 & 50.8 & 2.62 \\
\hline 240 & 17.1 & 0.27 & 740 & 25.5 & 1.40 \\
\hline 260 & 14.7 & 18.69 & 760 & 25.0 & 1.13 \\
\hline 280 & 20.3 & 30.90 & 780 & 61.0 & 0.21 \\
\hline 300 & 15.9 & 0.83 & 800 & 69.6 & 4.74 \\
\hline 320 & 14.2 & 0.52 & 820 & 30.5 & 2.25 \\
\hline 340 & 37.3 & 0.73 & 840 & 35.3 & 0.92 \\
\hline 360 & 37.0 & 1.22 & 860 & 21.9 & 0.50 \\
\hline 380 & 14.0 & 0.62 & 880 & 66.5 & 1.43 \\
\hline 400 & 17.4 & 1.19 & 900 & 37.9 & 1.77 \\
\hline 420 & 18.4 & 0.00 & 920 & 59.6 & 2.56 \\
\hline 440 & 66.5 & 1.06 & 940 & 26.1 & 1.11 \\
\hline 460 & 65.2 & 1.04 & 960 & 24.4 & 0.81 \\
\hline 480 & 15.2 & 0.50 & & & \\
\hline
\end{tabular}




\begin{tabular}{|c|c|c|c|}
\hline Samp le & ${\underline{\text { Total } \mathrm{CaCO}_{3}}}_{3}$ & $<\underline{62 \mu \mathrm{CaCO}}_{3}$ & Sand \\
\hline 20 & 73.1 & 71.57 & 5.75 \\
\hline 40 & 75.7 & 64.79 & 20.23 \\
\hline 60 & 37.8 & 18.57 & 5.50 \\
\hline 80 & 33.2 & 4.55 & 5.52 \\
\hline 100 & 25.0 & 14.91 & 1.54 \\
\hline 120 & 55.1 & 20.28 & 3.75 \\
\hline 140 & 47.1 & 33.28 & 1.94 \\
\hline 160 & 37.1 & 25.50 & 17.10 \\
\hline 180 & 25.4 & 15.85 & 6.43 \\
\hline 200 & 57.0 & 41.70 & 4.62 \\
\hline 220 & 38.2 & 15.70 & 3.69 \\
\hline 240 & 36.3 & 14.40 & 0.16 \\
\hline 260 & 29.8 & 13.40 & 0.65 \\
\hline 280 & 8.5 & 10.10 & 3.10 \\
\hline 300 & 17.2 & 11.60 & 18.61 \\
\hline 320 & 26.7 & 13.40 & 1.17 \\
\hline 340 & 51.0 & 51.00 & 4.57 \\
\hline 360 & 44.7 & 36.10 & 4.36 \\
\hline 380 & 56.4 & 42.00 & 5.61 \\
\hline 400 & 63.2 & 57.90 & 6.83 \\
\hline 420 & 42.0 & 32.80 & 2.58 \\
\hline 440 & 45.5 & 39.40 & 1.62 \\
\hline 460 & 49.9 & 21.80 & 1.54 \\
\hline
\end{tabular}


CORE V19-261

\begin{tabular}{|c|c|c|c|}
\hline ample & ${\underline{\text { Tota } 1 \quad \mathrm{CaCO}_{3}}}_{3}$ & $<\underline{62 \mu \quad \mathrm{CaCO}}_{3}$ & Sand \\
\hline 480 & 45.2 & 41.20 & 2.18 \\
\hline 500 & 62.9 & 58.30 & 6.08 \\
\hline 520 & 58.9 & 26.70 & 2.25 \\
\hline 540 & 32.3 & 23.20 & 1.74 \\
\hline 560 & 50.4 & 39.70 & 4.79 \\
\hline 580 & 58.4 & 56.10 & 6.35 \\
\hline 600 & 68.5 & 71.40 & 6.60 \\
\hline 620 & 68.7 & 51.10 & 5.69 \\
\hline 640 & 45.0 & 39.10 & 6.24 \\
\hline 660 & 28.0 & 16.90 & 1.51 \\
\hline 680 & 37.0 & 26.52 & 5.61 \\
\hline 700 & 34.8 & 23.21 & 2.95 \\
\hline 720 & 20.0 & 7.37 & 1.75 \\
\hline 740 & 19.2 & 3.27 & 0.94 \\
\hline 760 & 23.3 & 14.17 & 1.35 \\
\hline 780 & 34.3 & 27.08 & 3.43 \\
\hline 800 & 49.1 & 40.21 & 2.82 \\
\hline 820 & 34.5 & 23.65 & 2.09 \\
\hline 840 & 30.0 & 17.21 & 5.02 \\
\hline 860 & 37.6 & 24.22 & 7.26 \\
\hline 880 & 28.9 & 16.39 & 3.78 \\
\hline 900 & 33.8 & 16.04 & 0.00 \\
\hline 920 & 23.5 & 14.66 & 6.04 \\
\hline 940 & 37.5 & 16.59 & 2.94 \\
\hline 960 & 48.6 & 4.33 & 0.65 \\
\hline
\end{tabular}


CORE V19-263

CORE V19-278

\begin{tabular}{|c|c|c|c|c|c|}
\hline Samp le & $\% \mathrm{CaCO}_{3}$ & $\%$ Sand & Sample & $\underline{\mathrm{CaCO}}_{3}$ & $\%$ Sand \\
\hline 20 & 9.0 & 39.12 & 20 & 28.2 & 0.23 \\
\hline \multirow[t]{2}{*}{31} & 7.3 & 21.76 & 40 & 22.6 & 0.07 \\
\hline & & & 60 & 22.2 & 0.09 \\
\hline \multicolumn{2}{|l|}{ CORE V19-264 } & & 80 & 10.9 & 0.09 \\
\hline 20 & 19.4 & 57.21 & 100 & 14.6 & 0.13 \\
\hline 40 & 20.5 & 7.21 & 120 & 19.7 & 3.21 \\
\hline 60 & 23.6 & 7.80 & 140 & 25.9 & 0.42 \\
\hline 80 & 19.8 & 0.67 & 160 & 23.6 & 0.06 \\
\hline 98 & 29.3 & 2.26 & 180 & 17.3 & 0.03 \\
\hline \multicolumn{2}{|l|}{ CORE V19-265 } & & 200 & 19.8 & 0.07 \\
\hline 20 & 27.6 & & 220 & 25.0 & 0.02 \\
\hline 40 & 22.3 & & 240 & 17.1 & 0.65 \\
\hline 60 & 18.7 & & 260 & 24.6 & 0.08 \\
\hline 80 & 18.0 & & 280 & 15.2 & 0.58 \\
\hline 100 & 24.8 & & 300 & 19.2 & 0.14 \\
\hline 120 & 20.4 & & 320 & 18.8 & 1.01 \\
\hline 140 & 8.8 & & 340 & 16.8 & 0.32 \\
\hline 160 & 21.1 & & 360 & 18.6 & 0.52 \\
\hline 180 & 5.4 & & 380 & 20.4 & 0.76 \\
\hline 200 & 41.8 & & 400 & 21.0 & 0.14 \\
\hline 220 & 7.1 & & 420 & 15.5 & 0.06 \\
\hline 240 & 6.4 & & 440 & 13.4 & -- \\
\hline \multirow[t]{3}{*}{260} & 4.4 & & 460 & 4.1 & 0.11 \\
\hline & & & 480 & 13.4 & 0.07 \\
\hline & & & 500 & 7.8 & 0.05 \\
\hline
\end{tabular}


CORE V19-278

\begin{tabular}{|c|c|c|}
\hline Samp 1e & $\% \mathrm{CaCO}_{3}$ & $\%$ sand \\
\hline 520 & 18.2 & 0.43 \\
\hline 540 & 14.3 & 0.08 \\
\hline 560 & 16.1 & 0.28 \\
\hline 580 & 16.7 & 0.34 \\
\hline 600 & 17.3 & 0.12 \\
\hline 620 & 18.4 & 0.04 \\
\hline 640 & 18.6 & 0.61 \\
\hline 660 & 15.2 & 0.62 \\
\hline 680 & 18.2 & 0.21 \\
\hline 700 & 10.8 & 0.09 \\
\hline 720 & 12.6 & 0.11 \\
\hline 740 & 13.5 & 0.35 \\
\hline 760 & 5.6 & 0.08 \\
\hline 780 & 14.3 & 0.52 \\
\hline 800 & 15.0 & 0.37 \\
\hline 820 & 11.1 & 0.09 \\
\hline 840 & 14.8 & 0.56 \\
\hline 860 & 13.6 & 0.37 \\
\hline 880 & 17.3 & 0.41 \\
\hline 900 & 8.6 & 0.04 \\
\hline 920 & 9.8 & 0.62 \\
\hline 940 & 3.6 & 0.03 \\
\hline 960 & 12.6 & 0.08 \\
\hline 980 & 10.1 & 0.22 \\
\hline
\end{tabular}


CORE V19-280

\begin{tabular}{|c|c|c|c|c|c|}
\hline Sample & $\underline{\mathrm{CaCO}}_{3}$ & $\%$ Sand & Samp le & $\% \mathrm{CaCO}_{3}$ & $\%$ sand \\
\hline 20 & 28.0 & 1.22 & 500 & 35.9 & 0.97 \\
\hline 40 & 28.2 & 1.41 & 520 & 34.7 & 1.23 \\
\hline 60 & 24.5 & 0.83 & 540 & 31.7 & 1.09 \\
\hline 80 & 27.2 & 0.56 & 560 & 28.7 & 1.01 \\
\hline 100 & 23.3 & 0.76 & 580 & 39.1 & 1.62 \\
\hline 120 & 26.7 & 0.68 & 600 & 44.5 & 2.17 \\
\hline 140 & 24.6 & 0.87 & 620 & 55.8 & 3.02 \\
\hline 160 & 27.7 & 0.97 & 640 & 62.9 & 3.16 \\
\hline 180 & 45.8 & 1.99 & 660 & 56.2 & 3.01 \\
\hline 200 & 35.5 & 1.83 & 680 & 47.2 & 1.98 \\
\hline 220 & 34.2 & 1.17 & 700 & 30.7 & 1.82 \\
\hline 240 & 23.5 & 0.43 & 720 & 29.2 & 1.11 \\
\hline 260 & 28.5 & 0.64 & 740 & 42.3 & 1.62 \\
\hline 280 & 35.4 & 1.09 & 760 & 31.6 & 1.06 \\
\hline 300 & 29.3 & 0.69 & 780 & 31.7 & 1.12 \\
\hline 320 & 27.4 & 0.88 & 800 & 41.4 & 1.67 \\
\hline 340 & 30.6 & 1.02 & 820 & 26.0 & 0.37 \\
\hline 360 & 40.9 & 2.01 & 840 & 30.9 & 0.89 \\
\hline 380 & 26.8 & 1.07 & 860 & 23.4 & 0.26 \\
\hline 400 & 26.1 & 0.73 & 880 & 19.2 & 0.18 \\
\hline 420 & 28.4 & 0.84 & 900 & 25.7 & 0.17 \\
\hline 440 & 26.5 & 0.43 & 920 & 38.1 & 0.53 \\
\hline 460 & 31.4 & 1.13 & 940 & 67.5 & 2.01 \\
\hline 480 & 22.8 & 0.36 & 960 & 28.4 & 1.43 \\
\hline
\end{tabular}


CORE V19-280

$\begin{array}{rll}\text { Sample } & \underline{\text { \% CaCO}}_{3} & \text { \% Sand } \\ 980 & 57.6 & 1.87 \\ 1000 & 58.2 & 1.73 \\ 1020 & 51.3 & 1.41 \\ 1040 & 27.1 & 1.09 \\ 1060 & 25.2 & 0.85 \\ 1080 & 22.3 & 0.63 \\ 1100 & 23.7 & 0.64 \\ 1120 & 21.0 & 0.52 \\ 1140 & 21.4 & 0.46 \\ 1160 & 26.6 & 0.55 \\ 1180 & 25.0 & 0.21 \\ 1200 & 24.0 & 0.32\end{array}$


CORE V19-281

\begin{tabular}{|c|c|c|c|}
\hline Samp le & $\underline{\text { Total }}^{\mathrm{CaCO}_{3}}$ & $<\underline{62 \mu} \mathrm{CaCO}_{3}$ & $\%$ Sand \\
\hline 20 & 53.2 & 54.14 & 7.96 \\
\hline 40 & 31.4 & 33.00 & 1.37 \\
\hline 60 & 36.5 & 7.50 & 0.41 \\
\hline 80 & 36.4 & 13.78 & 4.86 \\
\hline 100 & 31.1 & 10.63 & 0.78 \\
\hline 120 & 37.7 & 10.30 & 0.66 \\
\hline 140 & 34.8 & 12.24 & 2.32 \\
\hline 160 & 30.2 & 10.81 & 3.59 \\
\hline 180 & 26.5 & 5.00 & 0.36 \\
\hline 200 & 23.8 & 5.97 & 0.50 \\
\hline 220 & 27.8 & 4.00 & 0.53 \\
\hline 240 & 36.8 & 5.25 & 0.53 \\
\hline 260 & 43.7 & 34.59 & 1.11 \\
\hline 280 & 48.0 & 30.05 & 6.01 \\
\hline 300 & 51.2 & 8.04 & 3.50 \\
\hline 320 & 42.2 & 16.20 & 1.77 \\
\hline 340 & 63.1 & 19.69 & 7.56 \\
\hline 360 & 40.0 & 3.13 & 2.55 \\
\hline 380 & 48.2 & 24.27 & 8.40 \\
\hline 400 & 57.1 & 18.86 & 3.09 \\
\hline 420 & 37.8 & 6.16 & 2.33 \\
\hline 440 & 43.8 & 13.41 & 2.46 \\
\hline 460 & 44.1 & 6.22 & 2.96 \\
\hline 480 & 40.3 & 16.79 & 0.81 \\
\hline
\end{tabular}




\begin{tabular}{|c|c|c|c|}
\hline Sample & $\underline{T o t a 1}^{\mathrm{CaCO}}{ }_{3}$ & $<\underline{62 \mu \quad \mathrm{CaCO}_{3}} 3$ & $\%$ Sand \\
\hline 500 & 32.1 & 22.24 & 2.45 \\
\hline 520 & 43.4 & 5.57 & 0.88 \\
\hline 540 & 41.4 & 13.56 & 1.90 \\
\hline 560 & -- & 45.73 & 7.01 \\
\hline 580 & 46.5 & 38.16 & 3.61 \\
\hline 600 & 28.3 & 9.41 & 0.42 \\
\hline 620 & 46.8 & 35.66 & 2.54 \\
\hline 640 & 47.2 & 33.60 & 4.15 \\
\hline 660 & 49.8 & 34.82 & 2.65 \\
\hline 680 & 42.7 & 17.01 & 1.66 \\
\hline 700 & 27.8 & 4.08 & 0.20 \\
\hline 720 & 28.0 & 10.13 & -- \\
\hline 740 & 31.4 & 8.79 & 0.67 \\
\hline 760 & 38.4 & 12.69 & 0.85 \\
\hline 780 & 47.6 & 23.23 & 0.85 \\
\hline 800 & 33.9 & 11.29 & 0.59 \\
\hline 820 & 46.3 & 19.20 & 2.42 \\
\hline 840 & 35.4 & 21.60 & 0.61 \\
\hline 860 & 23.6 & 19.90 & 2.20 \\
\hline 880 & 42.7 & 25.43 & 0.39 \\
\hline 900 & 22.3 & 15.24 & 0.44 \\
\hline 920 & 28.2 & 17.37 & 0.07 \\
\hline 940 & 22.9 & 5.08 & -- \\
\hline 960 & 33.8 & 25.05 & 0.96 \\
\hline
\end{tabular}




\begin{tabular}{|c|c|c|c|}
\hline Samp 1e & ${\mathrm{Tota} 1 \mathrm{CaCO}_{3}}_{3}$ & $<\underline{62 \mu \mathrm{CaCO}}_{3}$ & $\%$ Sand \\
\hline 980 & 32.2 & 19.73 & 1.56 \\
\hline 1000 & 33.6 & 3.40 & 0.11 \\
\hline 1020 & 61.8 & -- & - \\
\hline 1040 & 53.6 & -- & -- \\
\hline 1060 & 34.0 & -- & - \\
\hline 1080 & 34.4 & - & $\ldots$ \\
\hline 1100 & 33.7 & - & $\ldots$ \\
\hline 1120 & 40.4 & - & -. \\
\hline 1140 & 36.7 & -- & $\ldots$ \\
\hline 1160 & 46.7 & -- & -. \\
\hline 1180 & 40.6 & -- & -- \\
\hline 1200 & 79.0 & -- & -- \\
\hline 1220 & 64.4 & -- & - \\
\hline 1240 & 68.3 & - & - \\
\hline
\end{tabular}


$\underline{\text { Sample }}$

20

40

60

80

100

120

140

160

180

200

220

240

260

280

300

320

340

360

380

400

420

440

460

480
$\underline{\mathrm{CaCO}}_{3}$

83.9

64.2

35.9

25.6

28.2

37.5

28.3

36.0

40.1

39.9

36.3

54.2

85.1

69.7

64.2

70.0

70.3

82.4

38.0

60.0

50.7

60.1

79.7

64.6
$\%$ Sand

9.16

6.31

3.09

1.02

1.13

1.23

0.97

0.83

1. 32

1.33

1.16

4.85

5.76

4.76

4.83

5.01

4.91

6.32

2.02

3.89

4.06

4.01

6.22

5.85 $\underline{\text { Sample } \quad \underline{\mathrm{CaCO}}_{3} \quad \% \text { Sand }}$

500

51.2

3.67

520

75.4

5.97

540

60.0

3.98

560

48.2

4.02

580

46.1

4.13

600

87.8

7. 11

620

79.2

6.88

640

58.0

4.42

660

36.2

2. 14

680

43.8

2.89

700

47.2

2.56

720

48.8

2.67

740

43.5

2.73

43.7

2.56

58.0

5.02

53.2

4.23

47.8

2.16

840

49.9

2.24

860

51.2

2.03

880

60.3

2.36

900

59.0

1.98

65.1

4.16

920

65.1

4.1 


\section{CORE CH99-38}

204

\begin{tabular}{|c|c|c|c|c|c|}
\hline Samp le & $\stackrel{\mathrm{CaCO}}{3}_{3}$ & $\%$ Sand & Samp 1e & $\% \mathrm{CaCO}_{3}$ & $\%$ Sand \\
\hline 20 & 3.41 & 5.00 & 500 & 2.86 & 1.12 \\
\hline 40 & 2.52 & 3.20 & 520 & 3.41 & 0.72 \\
\hline 60 & 1.83 & 4.00 & 540 & 3.18 & 0.83 \\
\hline 80 & 1.38 & 3.21 & 560 & 2.98 & 6.23 \\
\hline 100 & 3.06 & 0.72 & 580 & 3.35 & 5.25 \\
\hline 120 & 3.71 & 1.03 & 600 & 1.86 & 2.16 \\
\hline 140 & 2.09 & 1.73 & 620 & 3.30 & 2.38 \\
\hline 160 & 1.72 & 0.66 & 640 & 2.53 & 1.73 \\
\hline 180 & 2.23 & 4.12 & 660 & 1.39 & 0.73 \\
\hline 200 & 2.63 & 3.67 & 680 & 2.54 & 2.43 \\
\hline 220 & 3.02 & 4.23 & 700 & 2.63 & 9.26 \\
\hline 240 & 3.19 & 6.12 & 720 & 4.13 & 11.10 \\
\hline 260 & 2.92 & 7.76 & 740 & 3.29 & 6.21 \\
\hline 280 & 2.31 & 7.23 & 760 & 2.86 & 2.22 \\
\hline 300 & 1.92 & 2.19 & 780 & 2.71 & 1.38 \\
\hline 320 & 1.76 & 0.63 & 800 & 3.29 & 2.19 \\
\hline 340 & 1.82 & 1.38 & 820 & 3.92 & 3.38 \\
\hline 360 & 2.51 & 2.22 & 840 & 3.36 & 1.80 \\
\hline 380 & 2.42 & 0.58 & 860 & 2.18 & 1.30 \\
\hline 400 & 2.67 & 12.12 & 880 & 2.21 & 2.50 \\
\hline 420 & 4.04 & 9.03 & 900 & 1.62 & 3.36 \\
\hline 440 & 3.96 & 2.16 & 920 & 3.21 & 7.25 \\
\hline 480 & 3.34 & 2.41 & 940 & 4.02 & 6.14 \\
\hline & & & 960 & 3.96 & 0.68 \\
\hline
\end{tabular}




\begin{tabular}{|c|c|c|}
\hline Sample & $\underline{\mathrm{CaCO}}_{3}$ & $\%$ Sand \\
\hline 980 & 4.11 & 1.77 \\
\hline 1000 & 2.97 & 2.23 \\
\hline 1020 & 2.86 & 2.56 \\
\hline 1040 & 2.32 & 4.25 \\
\hline 1060 & 3.01 & 5.03 \\
\hline 1080 & 3.22 & 3.22 \\
\hline 1100 & 2.87 & 0.78 \\
\hline 1120 & 2.63 & 0.65 \\
\hline 1140 & 2.31 & 1.72 \\
\hline 1160 & 1.72 & 1.93 \\
\hline 1175 & 3.37 & 2.16 \\
\hline
\end{tabular}


CORE CH99-39

\begin{tabular}{|c|c|c|c|c|c|}
\hline Sample & $\underline{\mathrm{CaCO}}_{3}$ & $\%$ Sand & Sample & $\underline{\mathrm{CaCO}}_{3}$ & $\%$ Sand \\
\hline 20 & 2.52 & 37.67 & 440 & 1.62 & 0.75 \\
\hline 40 & 2.51 & 1.00 & 460 & 3.23 & 0.92 \\
\hline 60 & 1.82 & 1.00 & 480 & 3.03 & 5.18 \\
\hline 80 & 3.28 & 11.00 & 500 & 2.42 & 2.17 \\
\hline 100 & 2.93 & 42.10 & $520^{\circ}$ & 1.67 & 3.46 \\
\hline 120 & 2.04 & 9.03 & 540 & 1.72 & 1.37 \\
\hline 140 & 1.37 & 0.31 & 560 & 2.18 & 2.34 \\
\hline 160 & 1.84 & 2.42 & 580 & 2.16 & 2.66 \\
\hline 180 & 3.35 & 0.71 & 600 & 2.72 & 2.32 \\
\hline 200 & 2.93 & 0.68 & 620 & 1.64 & 3.23 \\
\hline 220 & 3.03 & 1.03 & 640 & 2.35 & 3.38 \\
\hline 240 & 2.24 & 1.77 & 660 & 2.57 & 2.59 \\
\hline 260 & 1.73 & 3.69 & 680 & 3.02 & 0.42 \\
\hline 280 & 2.23 & 3.72 & 700 & 3.11 & 0.93 \\
\hline 300 & 2.89 & 1.42 & 720 & 1.78 & 1.63 \\
\hline 320 & 2.22 & 0.73 & & & \\
\hline 340 & 1.83 & 0.62 & & & \\
\hline 360 & 1.93 & 2.18 & & & \\
\hline 380 & 2.56 & 1.03 & & & \\
\hline 400 & 2.71 & 2.46 & & & \\
\hline 420 & 2.18 & 1.77 & & & \\
\hline
\end{tabular}


CORE CH99-41

\begin{tabular}{|c|c|c|c|c|c|}
\hline Samp 1e & $\% 62 \mu \quad \mathrm{CaCO}_{3}$ & $\%$ Sand & Sample & $\% \quad 62 \mu \quad \mathrm{CaCO}_{3}$ & $\%$ Sand \\
\hline 20 & 4.09 & 0.73 & 500 & 4.07 & 1.04 \\
\hline 40 & 3.64 & 0.41 & 520 & 3.34 & 3.10 \\
\hline 60 & 5.14 & 2.12 & 540 & 2.95 & 1.63 \\
\hline 80 & 3.26 & 1.92 & 560 & 6.28 & 0.95 \\
\hline 100 & 4.38 & 2.73 & 580 & 10.59 & 0.81 \\
\hline 120 & 4.96 & 0.47 & 600 & 5.75 & 0.75 \\
\hline 140 & 4.46 & 1.73 & 620 & 2.57 & 1.45 \\
\hline 160 & 2.98 & 1.03 & 640 & 5.55 & 0.62 \\
\hline 180 & 3.72 & 1.19 & 660 & 5.25 & 1.97 \\
\hline 200 & 4.10 & 2.02 & 680 & 4.95 & 1.06 \\
\hline 220 & 4.27 & 1.17 & 700 & 4.35 & 1.73 \\
\hline 240 & 3.85 & 1.28 & 720 & 3.46 & 1.68 \\
\hline 260 & 3.05 & 0.92 & 740 & 5.37 & 0.90 \\
\hline 280 & 8.94 & 0.68 & 760 & 3.78 & 0.58 \\
\hline 300 & 3.52 & 1.09 & 780 & 3.30 & 0.39 \\
\hline 320 & 5.06 & 1.97 & 800 & 3.55 & 0.01 \\
\hline 340 & 4.56 & 0.40 & 820 & 1.50 & 0.82 \\
\hline 360 & 5.48 & 1.59 & 840 & 2.15 & 0.62 \\
\hline 380 & 4.86 & 0.78 & 860 & 2.37 & 0.40 \\
\hline 400 & 4.96 & 0.45 & & & \\
\hline 420 & 3.10 & 0.54 & & & \\
\hline 440 & 3.17 & 0.95 & & & \\
\hline 460 & 2.56 & 0.47 & & & \\
\hline 480 & 6.12 & 0.88 & & & \\
\hline
\end{tabular}


APPENDIX III

Analytical Methods 


\section{$\underline{\text { Percent Sand }}$}

1. Approximately 1 to 2 grams of sediment were placed in a pre-weighed 50 m1. beaker and dried for at least 8 hours at $110^{\circ} \mathrm{C}$.

2. The samples were removed to a dessicator to cool and then weighed. Sample weight was determined by subtracting the beaker weight from the total weight.

3. About 20 to $30 \mathrm{~m} 1$ of sodium metaphosphate solution were added to each beaker and the samples were disaggregated. The samples were left to stand approximately 24 hours.

4. The samples were washed through a $62.5 \mu$ sieve and the silt and clay fraction collected in a $250 \mathrm{ml}$. beaker.

5. When thoroughly washed, the sand fractions were rinsed into $50 \mathrm{ml}$ beakers and placed in an oven at $110^{\circ} \mathrm{C}$ until completely dry.

6. The silt and clay fractions were allowed to stand undisturbed for one to two days.

7. The sand fractions and beakers weighea and the percent sand calculated. The sand fractions were placed in labeled vials.

\section{Percent Calcium Carbonate in the Silt and Clay Fractions}

1. After standing for 1 to 2 days, the clear supernatants were poured from the $250 \mathrm{ml}$. beakers containing the silt-clay fraction and the remaining sediment washed into the same $50 \mathrm{ml}$ beakers as used in determining percent sand.

2. The silt-clay fractions were dried for about 12 hours at $110^{\circ} \mathrm{C}$.

3. The samples were placed in a dessicator to cool and then weighed. Sample weights were determined by subtracting the beaker weights from the total 
weight.

4. 2N HC1 was added to each beaker and the beakers were allowed to stand for about one hour.

5. During this time, Millipore ${ }^{R}$ filters were weighed and placed in numbered petrie dishes corresponding to the sample numbers.

6. Distilled water was added to the beakers and the supernatants were washed (decanted) onto their corresponding Millipore filters. Distilled water was added to the samples and decanted several times.

7. The filters were washed several times with distilled water.

8. The filters were placed in the beakers with their samples and dried at $110^{\circ} \mathrm{C}$ for about 8 hours or until dry.

9. The samples and filters were cooled in a dessicator and weighed.

10. The acidified sample weight was determined by subtracting the filter weight and the beaker weight from the final weight.

11. Carbonate content was determined by:

$$
\frac{\text { (origlna1 weight) - (acldified weight) }}{\text { original weight }} \times 100
$$

Percent Organic Carbon

1. A 0.25 to $1.0 \mathrm{gram}$ sample was dried at $110^{\circ} \mathrm{C}$ for 8 hours and weighed.

2. The sample was acidified in $2 \mathrm{~N} H C 1$ to remove calcium carbonate.

3. The sample was washed into a Leco ${ }^{R}$ filter crucible and rinsed several times with distilled water.

4. The crucible'was covered with metal foil and labelled.

5. The sample was combusted in a Leco induction furnace and the percent organic carbon determined. 


\section{Clay Mineral Analyses}

1. Samples were acidified in acetic acid and disaggregated completely.

2. The less-than- $2 \mu$ fraction was separated by centrifugation.

3. The supernatant in each centrifuge tube was poured through a Selas Flotronics ${ }^{R}$ silver filted and then air dried.

4. The silver filters were placed in a Norelco X-ray diffractometer (Cu $\mathrm{K} \propto, 40 \mathrm{ma}, 40 \mathrm{Kv}$ ) and scanned from $2^{\circ}$ to $40^{\circ} 20$ at $2^{\circ} / \mathrm{min}$.

5. The filters were then placed in a dessicator containing ethylene glycol and glycolated at $70^{\circ} \mathrm{C}$ for at least 4 hours.

6. The filters were then scanned again from $2^{\circ}$ to $40^{\circ}$ above the previous untreated trace.

7. Certain of the samples were then heated to $400^{\circ} \mathrm{C}$ and $550^{\circ} \mathrm{C}$ and rerun.

A baseline was sketched on the glycolated trace and the areas of the major peaks determined by counting the enclosed squares within the peak and the baseline. The following peak weightings were used (Biscaye, 1965) to determine the percentages of the clay minerals:

$1 \mathrm{x}$ area of the $17 \AA$ glycolated montmorillonite peak

$4 \mathrm{x}$ area of the $10 \AA$ glycolated illite peak

$2 \mathrm{x}$ area of the $7 \AA$ kaolinite-chlorite peak

Kaolinite and chlorite were divided based on the relative areas of the two peaks in the kaolinite-chlorite $3.5 \AA$ doublet (kaolinite, $3.58 \AA$; chlorite, $3.54 \AA)$.

The four weighted peak areas were summed and the weighted area of each mineral times 100 was divided by the sum of the areas to give the percentage of each mineral. 
BIOGRAPHY

\section{Brian Douglas Bornhold}

Born: Kitchener, Ontario, Canada - December 13, 1945

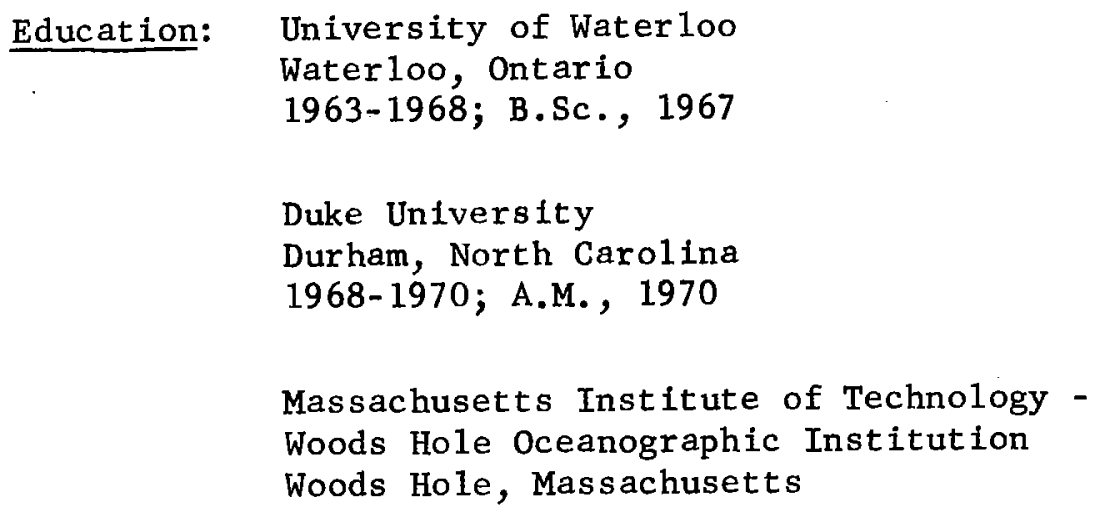

Professional Experience:

May 1968 - Sept. 1968

Apri1 1967 - Sept. 1967

May 1966 - August 1966

May 1966 - Sept. 1966

Jan. 1965 - April 1965

April 1964 - Aug. 1964
Canada Centre for Inland Waters Burlington, Ontario Sr. Field Assistant

Geological Survey of Canada Dr. P. F. Karrow Laboratory Assistant

Rio Tinto Canadian Exploration 120 Adelaide Street West Toronto, Ontario Geologist's Assistant

Lornex Mining Corporation Ashcroft, British Columbia Geologist's Assistant

Tamper Division

Canada Iron Lachine, P.Q.

Engineer's Assistant

Tamper Division, Canada Iron Lachine, P.Q.

Engineer's Assistant 
Academic Awards:

1968 - 1969 Duke University Geology Department Fellowship

1969 - 1970 National Science Foundation Predoctoral Traineeship in Oceanography, Duke University Marine Laboratory

1970 - 1973 Woods Hole Oceanographic Institution Research Fellowship

Papers Published:

Bornhold, B.D., 1969, Marine mineral resources: North Carolina Engineer, v. XXVI, p. 25-34.

Pilkey, O.H. and Bornhold, B.D., 1970, Gold distribution on the Carolina Continental margin - a preliminary report: U.S. Geol. Survey Prof. Paper 700C, p. c30-c34.

Bornhold, B.D. and Pilkey, O.H., 1971, Bioclastic turbidite sedimentation in Columbus Basin, Bahamas: Geol. Soc. Amer. Bul1., v. 82, p. 1341-1354.

Bornhold, B.D. and Milliman, J.D., 1973, Generic and environmenta1 considerations in the carbonate mineralogy and composition of serpulid (Polychaete) tubes: Jour. Geol., v. 81, p. 363-373.

Milliman, J.D. and Bornho1d, B.D., in press, Peak-heights versus peak area determination of calcite-aragonite mixtures: a discussion: Sedimentology.

Mascle, J.R., Bornhold, B.D., and Renard, V., in press, Diapiric structures off the Niger Delta: Am. Assoc. Petrol. Geol.

Bornhold, B.D., Mascle, J.R., and Harada, K., in press, Suspended matter in surface waters of the Eastern Gulf of Guinea: Marine Geology. 


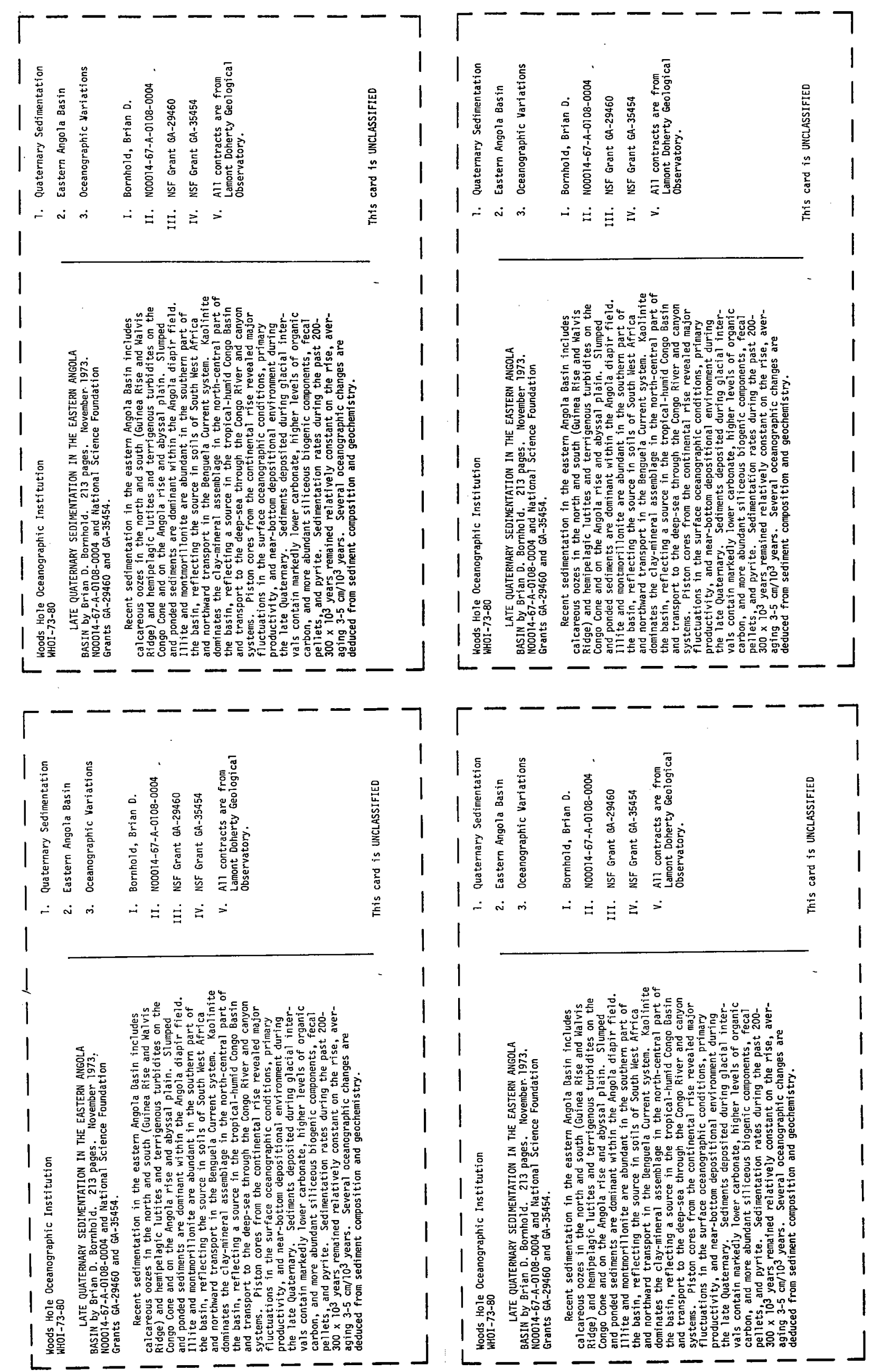


$-$ 